Andrews University

Digital Commons @ Andrews University

Master's Theses

Graduate Research

1977

\title{
Assessing Student Co-Curricular Needs and Interests Through an Objective Method
}

Peter J. McCann

Andrews University

Follow this and additional works at: https://digitalcommons.andrews.edu/theses

Part of the Education Commons

\section{Recommended Citation}

McCann, Peter J., "Assessing Student Co-Curricular Needs and Interests Through an Objective Method" (1977). Master's Theses. 175.

https://dx.doi.org/10.32597/theses/175

https://digitalcommons.andrews.edu/theses/175

This Thesis is brought to you for free and open access by the Graduate Research at Digital Commons @ Andrews University. It has been accepted for inclusion in Master's Theses by an authorized administrator of Digital Commons@Andrews University. For more information, please contact repository@andrews.edu. 
Andrews University

School of Graduate Studies

ASSESSING STUDENT CO-CURRICUIAR

NEEDS AND INTERESTS THROUGH

AN OBJECTIVE NETHOD

A Thesis Project

Presented in Partial Fulfillment

of the Requirements for the Degree

Master of Arts

\author{
by \\ Peter J. McCann \\ Niay 1977
}

Approval

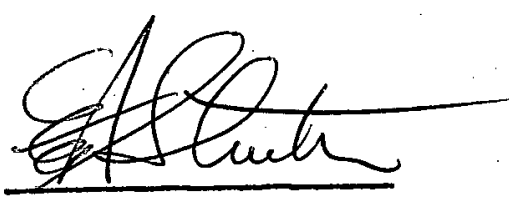




\section{ABSTRACT OF GRADUATE STUDENT RESEARCH Project}

\section{Andrews University}

Department of Education

Title: ASSESSING STUDENT CO-CURRICULAR NEEDS AND INTERESTS THROUGH AN OBJECTIVE METHOD

Name of Researcher: Peter J. McCann

Name and title of faculty adviser: Edward A. streeter, Ed.D.

Date completed: Nay 1977

\section{Problem}

Previous research has shown that when potential dropouts are actively involved in the school program, the dropout rate is reduced. Co-curricular activities have been found to be the most effective method of getting potential dropouts involved. The problem has been that implementation of co-curricular activities has relied on the subjective value judgment of administrators. rhis project attempted to develop an objective method for assessing student co-curricular needs and interests.

\section{Method}

There were three phases to this project. The first phase was an extensive review of the iiterature in order to determine factual evidence. The second phase was the development of testing instruments. The third phase was the field testing of the instruments for the purpose of assessing co-curricular needs and interests. 


\section{Results}

The results are that the patterns described in the Review of Literature were found to be present in the schools tested. The schools were found to be lacking co-curricular programs that interested students defined as potential dropouts.

\section{Conclusions}

As a result of this project, the schools tested need to make certain program changes and additions. Co-curricular needs and interests of the students can be objectively assessed and the results used to improve school programs. 
TABLE OF CONTENTS

Chapter

Page

I. INTRODUCTION TO THE PROBIEI ............ I

Purpose of the $s$ tudy................... 2

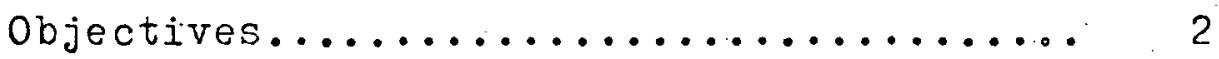

Need for the study.................. 3

Limitations........................ 4

Basic Assumptions................... 5

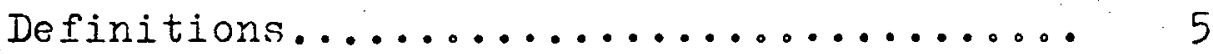

II. A REVIEW OF THE IITERATURF............. 7

Historical Viethodologies............. 8

Validity and Reliability............ 12

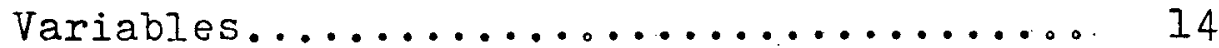

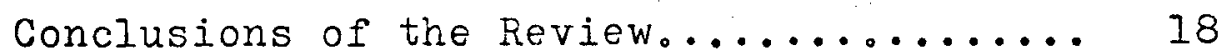

III。 METHODOLOGY......................... 19

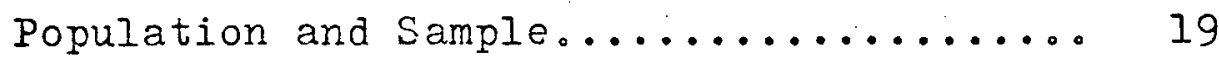

Description of the Instruments......... 21

Development of the Tests.............. 22

Method of Analysis: First student

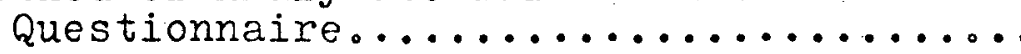

Method of Analysis: Second Student Questionnaire.

Teacher's Questionnaire. 
IV. RESULTS ...................... 32

Objective $1 \ldots \ldots \ldots \ldots \ldots \ldots \ldots \ldots \ldots \ldots$

St. Joseph.................... $3 I$

Bridgman...................... 36

Objective $2 \ldots \ldots \ldots \ldots \ldots \ldots \ldots \ldots \ldots \ldots \ldots$

S.t. Joseph.................... 39

Bridgman................. 41

Objective $3 . \ldots \ldots \ldots \ldots \ldots \ldots \ldots \ldots . \ldots \ldots$

Objective $4 \ldots \ldots \ldots \ldots \ldots \ldots \ldots \ldots \ldots . \ldots \ldots$

Objective $5 \ldots \ldots \ldots \ldots \ldots \ldots \ldots \ldots \ldots \ldots$

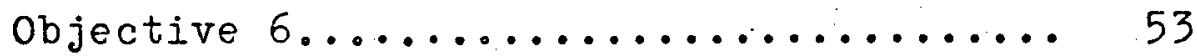

V. CONCLUSION AND RECOMNENDATIONS ......... 57

Bridgman High School.............. 57

St. Joseph High School............. 57

General Recommendation............. 58

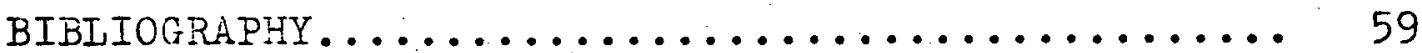

APPENDIX A............................. 61

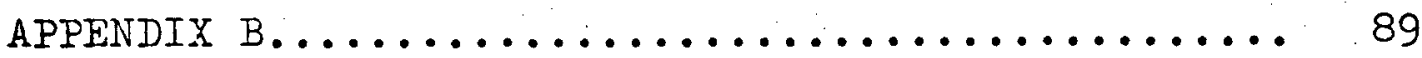

APPENDIX C............................... 95

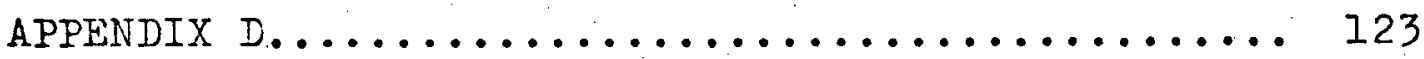

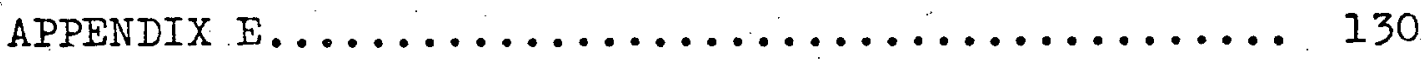




\section{IIST OF TABIES}

TABLE

PAGE

1. Socio-Economic Status of the students and

Participation - s.t. Joseph............. 32

2. Attitude and Participation - St. Joseph......33

3. Opportunity and Participation - St. Joseph.... 33

4. Relationship Between Participation and

Academics - St.Joseph................ 33

5. Leadership and Jembership - Sit. Joseph...... 34

6. Relationship of Program Track to Leadership

and Participation - St.Joseph........... 35

7. Ethnic Background and Participation - St.

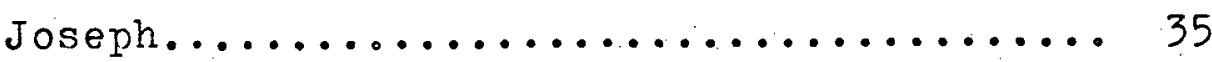

8. Socio-Economic Status of the students and

Participation - Bridgman............. 36

9. Attitude and Participation - Bridgman....... 37

10. Relationship Between Participation and

Academics - Bridgman.................. 37

11. Ieadership and Social Status - Bridgman...... 38

12. Participation and Program Track - Bridgman.... 38

13. Profile of Participants - st. Joseph........ 40

14. Profile of Non-Participants - St. Joseph..... 40

15. Profile of Potential Dropouts - S.t. Joseph.... 41

16. Profile of Participants - Bridgman......... 42

17. Profile of Non-Participants - Bridgman...... 43

18. Profile of Potential Dropouts - Bridgman..... 43 
19. Sample of St. Joseph High School Activity Choices from the First Questionnaire...... 44 20. Sample of Bridgman High School Activity

Choices from the First Questionnaire...... 45

21. St. Joseph High School Second Questionnaire

Items with Highest Percentage of

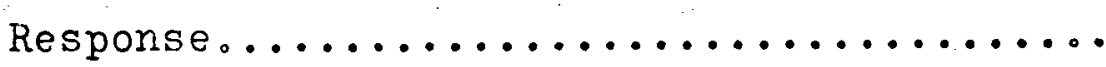
46

22. Bridgman High School Second Questionnaire

Items with Highest Percentage of

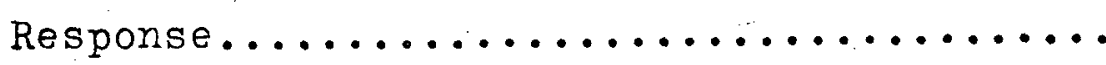

23. Activity Choices of St. Joseph High School

Teachers by Ranking Compared with student

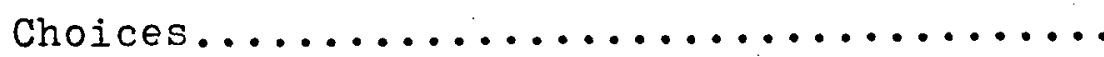
48

24. Activity Choices of Bridgman High School

Teachers by Ranking Compared with Student

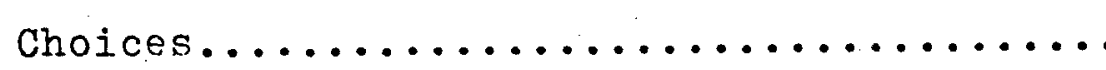
51

25. Source of Friends................... 54 26. Sources of Personal Satisfaction for

Participating students................ 54 27. Work Commitments and Transportation........ 55 


\section{CHAPTER I}

\section{INTRODUCTION TO THE PROBLEM}

In $1962,40 \%$ of all secondary public school students were dropouts (Iichter). These students came from homes with Iow educational backerounds and little involvement with the educational system. According to the study done by Iichter of intellectually capable students who were dropouts, the major cause leading to dropping out was credited to psychological problems related with negative attitudes toward the educational system.

In 1974 , the National dropout rate was down to $25 \%$ (Urdal) and further research by Urdal revealed that there. were variables that were $68 \%$ effective for predicting dropouts. These four variables were the educational level of the father, the student's attitude toward the educational system, the student's language skill scores, and the student's participation in co-curricular activities.

In 1975, Combs reflected the theory that the dropout was "the person for which education has no personal meaning." Under this theory, if the potential dropout could be provided with activities that had a personal meaning to him or which met his needs and interests, his attitude toward the system could be changed (Combs).

Therefore, the problem presented was how to assess 
the needs and interests of the students in regard to possible co-curricular programs that would enhance the student's attitude toward the educational system (Urdal).

\section{Purpose of the study}

The purpose of this study was to assess the present co-curricular program of two public secondary schools (See Chapter II) with regard to the rates of participation, certain demographic characteristics of the students in the activities, to identify potential dropouts, and to extract from the students possible alternatives that might better meet the needs and interests of the individuals who are not participating in the co-curricular program.

\section{Objectives}

1. To measure the Gestalt of student involvement in co-curricular activities.

2. To develop a profile of the students involved and not involved in activities with regard to certain demographic characteristics.

3. To determine from the students themselves, alternative programs to better meet their needs and interests.

4. To determine by objective methods, from existing and alternative programs, activities that interest the potential dropouts and the greatest 
number of students.

5. To determine if the faculty had the interest and skills needed to effectively run alternative programs.

6. To develop a standardized instrument usable by school administrators.

Need for the study

Most co-curricular activities came from the following sources: an administrator copying neighboring schools; an aggressive co-curricular programs director; an outside sponsoring agency; teachers seeking self-fulfillment; or community pressure (Ovard). Nillholen reported that the great majority of students depended on the schools for their social experiences. The people that needed the most input into the activities program were usually the ones that had the least. They were the students (Miliholen).

When the potential dropout lacked a positive attitude toward education, was under-achieving academically, had no parental pressure to finish, and there were no cocurricular programs that met his needs or interests, the school had failed. Therefore, a method needed to be developed for school administrators to go directly to the students on an objective basis and extract the information that would enable planning and revising programs to meet the needs and interests of the greatest number of students 
as well as the potential dropouts.

\section{Iimitations}

This study was primarily concerned with objectively assessing student co-curricular needs and interests. To do this, the study attempted certain functions. First, the study assessed the current rates of participation and demographic relationships between activities and the students. Secondly, the study tried to assess activity preferences with regard to certain demographic configurations. Thirdly, the study attempted to predict which activities had the greatest chance of increasing student participation rates, especially among potential dropouts.

This study did not attempt to assess the faculty attitudes. It did not try to correlate language skill scores with attitude or participation. This study did attempt to present a picture of activities participation with regard to the variables mentioned in the following chapters.

The findings of this study were applicable to the population studied only. They were not transferable. Hopefully, the techniques developed could be usable on a generalized basis. 
Basic Assumptions

Basic to this study was the reliability of the questionnaire as an instrument. It was also necessary that the sample populations could read the questions and answer them.

It was assumed that previous works used as the basis of this study were valid. If the foundation premises and theories were correct, this study could produce valid results.

Definitions

Co-curricular - semantic with extra-curricular. An activity that students engage in on a voluntary basis that generally was social or athletic in nature and carried no academic credit.

Demographic Characteristics - a construct of relationships between the student and other variables: socio-economic status, work, age, grade, sex, busing, GPA, etc。

Gestalt - configurationism; a synchronic construct of the integration of the parts - Gestalt psychology.

Socio-economic status - for this study, the summarization by Warner and Lunt in The Social Life of a Modern Community (Yale University Press, 
New Haven, 1941) is used. It is limited to three classifications instead of six and based on occupation alone. The three classes used for this study are lower class, middle class and upper-middle class.

Student Activities - for this study, meaning co-curricular. 


\section{A REVIEW OF THE IITERATURE}

From 1919 to 1976, there were scores of books and articles written on the extra-curricular phase of the educational program. During the half century that cocurricular programs had been in the American school systems, writers on the topic generally limited themselves to two areas: the management of such programs and assessing the programs. It was in the area of assessment that this study was aimed.

The assessment of co-curricular programs had two major phases. The first phase, which began almost as soon as extra-curricular programs started, was the assessment of programs on a subjective basis (Ovard). Under this system, programs were initiated and terminated on the basis of the beliefs of the administrators. In the second phase, which was less than thirty years old, objective inquiries were made of the student body, and the results were used subjectively in the decisions as to the types and extent of co-curricular programs (TompkinsTrump). 
Historical Methodologies

The basic method used throughout the history of assessing extra-curricular programs had been the questionnaire. Questionnaires had been developed to be used on students, to be completed by administrators, and to be completed by accrediting teams.

One of the first assessments of co-curricular activities by questionnaire was published in 1930 by Bellingrath. In this study, a sample of senior high school students was selected in five New Jersey and New York metro-area schools. The students were given a questionnaire which asked them to tell. What activities they were participating in and to list any offices held in that activity. Answers were compared to school records (Bellingrath).

Iittle significant work was done in this field until after World War II. Then, in 1950, the Office of Education published Tompkins' research. Tompkins had the students in Illinois schools complete a short questionnaire each day. The students were asked to check the activities they were going to be involved in that day. The students were also asked to suggest new activities. The information gathered each day was processed in the central office to establish participation rates. New programs were to be initiated on the basis of student suggestions (Tompkins). 
In 1957, Gordon published the results of his research on extra-curricular activities. Gordon was interested in determining if extra-curricular participation was related to social status. Using a questionnaire, Gordon asked the students to list their activities. He then asked the students to complete a sociometrics test. The results were that activities participation was related to social status (Gordon).

Although the experimental trend was to go to the students for assessing extra-curricular activities, the functional evaluation was still at the administrative level. This was evidenced by the 1960 edition of Evaluation Criteria. This book provided school administrators and visiting committees with a fourteen page checklist for "providing the factual background for evaluation."

Along this same line of administration evaluation of programs, the NEA published Profiles of Excellence in 1966. While the book covered the entire educational program, extra-curricular evaluation was done on only one page. The administrators were asked to give their opinion. In 1968, the Fresno California Unified School District published an HEW-funded, pilot study of a student needs and interest assessment. Extra-curricular interests were included. Under this method, randomly selected students were placed into seventy discussion groups. The conclu- 
sions the groups reached were the findings of the report (Fresno California Unified School District).

In the same year, the NASSP sponsored a study conducted by Glatthorn. The object of the study was how to get rebellious and uncommitted students involved in activities through the actions of the student council. Glatthorn recommended that administrators use open-ended questionnaires to be completed by the faculty members. Jacobson, in his book The Principalship: New Perspective, reported the dissertation work done by I.F. Millholen. Through the use of questionnaires completed by students in grades $9-12$, it was discovered that there was a difference in the rates of participation between large and small schools with small schools having the larger rates. There was difference in participation between 9 th and loth grades and 1 th and 12 th grades, with IIth and I2th grades dominating. Millholen discovered that the prime reason for students not participating was that the activities offered did not meet the needs and interests of the students (Jacobson).

By the 1970's, the method of using questionnaires to assess student participation and interests in extracurricular activities had become an accepted practice as witnessed by the HEW funded studies of Kassera and Tolbert. Both of these studies were done at the college level. A random sample was selected and given questionnaires to 
complete (Kassera and Tolbert).

Jacobson reported in 1973 the results of his questionnaire. Randomly selected students were asked to answer rating scales. The first questionnaire asked them to rate the source of activities that brought them the most personal meaning. The results were that extracurricular activities helped them develop friendships and a positive attitude toward school. Also, the students rated extra-curricular activities as the greatest source of personal satisfaction with unplanned peer activities as the least satisfying (Jacobson).

The question of reliability of questionnaires as a research instrument when assessing extra-curricular needs and interests arose. The next section will answer this question. 
Validity and Reliability

Although student questionnaires were used from the 1930 's until the present, the reliability of the data produced was seriously questioned. For example, The 7 th Mental lieasurement Yearbook carried criticisms of student attitude and inventory questionnaires. The critics for the yearbook made the generalized statement when reviewing William Cottle's School Interest Inventory that no. test labeled as attitude or inventory had reliability. However, while questionnaires were not accepted as valid, other techniques of assessing student attitudes and interests were developed. Iichter and associates spent 1954 through 1957 involved in a Iongitudinal study of dropouts. Through the use of psycho-diagnosis instruments, Iichter discovered that dropouts differentiated from other students on the basis of attitude toward school; they and their parents had negative attitudes toward school problems, and the students had poor academic grades. Iichter found that the schools were not meeting the dropouts' needs and interests. Through the use of special programs that met the needs and interests of the students, Lichter found a change in attitude and a decrease in the propensity to drop out (Iichter). The validity of student questionnaires was estab- 
lished by two longitudinal studies. The first study was published in 1963 by Urdal. Urdal identified potential dropouts through the use of variables and by subjecting the students to longitudinal testing. There were four major variables that identified the dropout:

- Language skill scores

- Educational level of the father

- Degree of participation in clubs and activities

- Attitude toward school

At the end of the longitudinal study, Urdal's method had been $68 \%$ correct (Urdal).

The second study that upheld the validity of student questionnaires was done by Maxey. Borrowing a technique similar to the Bellingrath study, Maxey administered a self-report test to a sample of high school students. He then compared the test answers with school records and found there was $81 \%$ to $86 \%$ accuracy in student answers. However, students did tend to answer nearly perfectly questions related to the variables of sex, age, income levels, etc. There was distortion when students were asked to report grades. Lower achieving students tended to over-report their marks (Maxey). 
Variables

Extra-curricular participation was subject to influence by variable effectors. Identification of these variables had been mostly through the use of student questionnaire techniques.

Assuming that the liaxey and Urdal studies were valid, then we can assume that other student questionnaires are also valid, and that the variables identified that influence extra-curricular participation are reliable.

Bellingrath identified sex, age and social status as effectors in activities participation. By studying those students involved in activities, he found that leadership in activities for male students was dependent on age, socio-economic background, and attitude toward school. It was not dependent on physical measurement, grades and school habits. However, for females, leadership was dependent on grades and school habits as well as physical measurement. There were two variables similar between males and females, age and socio-economic background. In coed activities, males tended to dominate (Bellingrath). The next attempt to identify variables influencing activities participation was done by Trump. This was a study undertaken for North Central Accrediting. Of over 3,500 students in grades $9-12$, Trump found that $25 \%$ did not participate in activities. Using a questionnaire, 
he discovered that grade level and socio-economic status did influence the type and rate of participation in activities. Activities tended to be dominated by upper classmen and higher socio-economic students. Trump also disclosed through his research that activities were not instituted for the purpose of meeting the needs and interests of the students (Trump).

Hand was quoted by Frederick in a 1959 publication. Hand used student record cards to determine which variables influenced student participation in extra-curricular activities. He found that the variables were the time the event was held, work commitments, residence, transportation, cost, parental attitude, and student selfconcept (Frederick).

Besides helping to establish the creditability of questionnaires, Urdal also identified certain variables that influenced both dropout rates and participation in activities. The variables were that dropouts had twice the absence rate of other students, had lower attitude toward school, lower socio-economic status, greater number of schools attended, and personal problems (Urdal).

Urdal also found that dropouts had a lower attitude toward academics, that absence was related to personal problems and grades received had little effect on dropout prevention. The key to dropout prevention was participation in extra-curricular activities. Participation had 
a strong correlation with an attitude for remaining in school (Urdal).

This Urdal study strongly upheld the findings of the Iichter study and the 1975 study by Hill. Personal involvement in the educational system by the student was a strong effector in dropout prevention (Hill).

Grinder did a 1967 study into occupational and social goals of youth through the use of questionnaires. As a finding of his study, Grinder discovered that students became involved in activities that had personal meaning to them. He identified three reasons for involvement: to fill expectation of social status; self-fulfillment; and sex gratification (Grinder).

A 1967 dissertation study done by Mccray in the Gary, Indiana high schools of the relationship between selected factors and the extent of student participation in cocurricular activities found that school size was not a variable in participation. He did find that cost to the student had a positive effect on participation; that there was a correlation between family background and participation; and that college prep students had more involvement in activities (McCray).

McCray's study supported the thesis of Ovard who wrote that activities were socio-economically oriented. The question of whether physical ability was an effector in participation rates of activities was the topic of 
the dissertation work of Thomas in 1968. She discovered that the relationship between physical fitness and four other variables (intellect, academic performance, occupational status of the parents, and co-curricular participation) was not significant. There was no relationship between physical fitness and the number of activities that female high school students participated in (Thomas). In his 1973 dissertation work, Sherrodd studied the relationship between attitude and participation in activities. Using the California Study Methods Survey, he found there was a direct relationship between participation and a positive attitude toward school. Sherrodd also found that participation was directly related to the school administrator's rating of the student on the basis of social ability, citizenship, scholastic potential and responsibility. Participation was found to be inversely related to ratings in leadership, social activity, timidity and character (Sherrodd). 
Conclusions of the Review

As a result of the review of literature, the most successful method of assessing co-curricular participation and interests was the student questionnaire. The question of the reliability of student questionnaires was not completely answered. However, based on the work of Urdal and Iraxey, the findings of any questionnaire could be used as generally reliable data. There is a high degree of error in this approach which must be taken into account.

The variables identified as influencing participation are attitude, socio-economic status, the orientation of the activities, opportunities and the type of activity.

It has been shown that if activities are instituted on the basis of the needs and interests of the students, they can have a positive effect on the students' attitude toward school. 
CHAPTER III

IVETHODOIOGY

Population and Sample

There were 350 students, grades 9-12, in Bridgman High School and just over 1,400 students, grades $9-12$, in St. Joseph High School. In keeping with the sample recommendations of the NEA ("Small Sample Techniques,". NEA Research Bulletin, 38, December 1960, p. 99) and the recommendations of Morgan and Krejcie ("Determining Sample Size for Research Activities," Educational and Psychological Nieasurement, 30, Autumn 1970, pp.607-610), a total of 188 students was used in Bridgman, 47 at each grade level, and a sample of 302 students, 75 at each grade level, was used in St. Joseph.

Due to conditions imposed by the schools for this study, pure random sampling was not possible. Instead, entire class sections were chosen to achieve as near as possible an equal division on the basis of sex and grade level.

At Bridgman High School the following students were questioned:

9 th Grade 2nd Hour Social Studies (Mr。 Fanaly) 6 th Hour Social Studies (Mr. Ridgeway)

loth Grade 2nd Hour Health (Mr. Planutis/Ms. Weaver) 


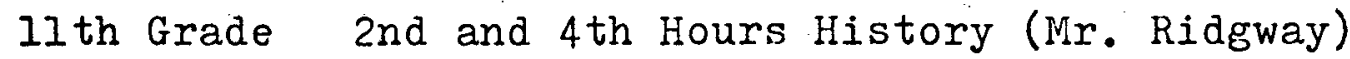

12th Grade 4 th and 5 th Hours Sociology (Mr. Fanaly)

At St. Joseph High school the following students were questioned:

9th Grade Ist and 3rd Hours American Political Behavior - Government (Mr. Denekes)

10th Grade Ist, 2nd, 3rd Hours Mathematics (Mr。 Muhlenkamp)

Ilth Grade $\}$ 3rd, 4th, 5th Hours History. (Mr. Harmon) $3 r d, 4$ th, 6th Hours History (Mr. Bruno)

The student questionnaires were administered in the normal classroom environment during the regularly scheduled program. The testing dates for Bridgman High School were March 30 th for the first test and Way 12 th for the second. Testing in St. Joseph High School was conducted April Ist and May 5 th.

Teacher sampling at both schools was done by total population. Questionnaires were distributed through the teachers' mailboxes with instructions to complete and return to the office by the specified date. The teachers' test at Bridgman was May 11th through May 13th. Teacher testing at St. Joseph was from Nay 3 rd to May 5 th. 
Description of the Instruments

In this study five different questionnaires were prepared.

The first questionnaire, containing 164 items, was written at the fifth grade vocabulary level. The students were asked not to give their names to avoid any possible conflict with the right to privacy laws. Based on the study done by Maxey, names were not necessary. This questionnaire was designed to gain data related to the variables of age, sex, grade level, academic grades, ethnic background, educational level of the father, program track, socio-economic level, attitude, opportunity to participate, participation, absenteeism, reasons for absence, and activity preferences. To determine the relationship between students and their activity patterns as well as their choices for possible alternative activities, the questionnaire was divided into four parts: demographics, current activities, selected alternative activities, and short answers. This information was subjected to data processing.

Because the results differed between the two schools, it was necessary to write a separate, second questionnaire for each school. Alternative activity items having a response greater than 14\% (Maxey) as well as all current activity items were written into each second questionnaire. Items appearing in the short answer part which did not 
appear on the alternative activities list were also entered into the second questionnaire. In addition, the second questionnaire asked for information related to age, sex, grade level, program track, academic grades, educational level of the father, socio-economic level, and attitude.

A separate questionnaire was prepared for the teachers in each school. There were two parts. The first part asked questions suggested by Cornell (Educational Accountability Through Fvaluation) as possible influencers of activity involvement. The variables asked were age, sex, years of teaching experience, degree held, department, type of college, and personal activity history. The second part was the same as the students' second questionnaire with regard to activities interests. The objective was to see if the teachers had the interest and or skills to advise or coach the items selected by the students and if there were relationships between teacher choices and the variables mentioned.

\section{Development of the rests}

The tests used in this study were developed on the basis of previous work done in the area of student questionnaires. (See Review of Iiterature) The prime sources for the questions were the studies done under Hew grants at the University of Wisconsin, the National Longitudinal 
Study and Tompkins. Other sources included Viaxey, Cohen ("Student Characteristics: Personality and Dropout Propensity"), and Greive ("A Survey of Student Attitudes"). While the basic questions were used, the structure was changed and the reading level reduced.

The validity of the tests was based on the work of Maxey. He established the accuracy of student questionnaires at $81 \%$ to $86 \%$. The reliability of the teacher's questionnaire is not established. It is suggested that the findings of this study be implemented to see if the teachers will actually advise or coach the activities in which they indicated an interest (Maxey).

Method of Analysis: First Student Questionnaire

In order to establish a Gestalt of the student population, identify the percentage of potential dropouts, and obtain a profile of the students who are involved in cocurricular activities, a simple descriptive type of analysis was used for the first questionnaire. The completed questionnaires were reduced to keypunch cards and then processed at the Andrews University Computer Center. This method pertained to the first 159 questions only. Because the last five questions were subjective, they were scored manually。

The responses to the questionnaire were divided into categories as follows: 
1. Total sample responses

2. Students who participate in activities

3. Students in athletics only

4. Students in non-athletics only

5. Students in both athletics and non-athletics

6. Non-participants

7. Potential dropouts

8. Working non-participants

9. Bused non-participants

10. Student senate members

11. Officers

12. Socio-economic status

In order for a student's response to be categorized into one of the above, the responses had to meet certain criteria.

1. Total Sample Responses - This was a measurement of how the entire sample answered each of the questions. The objective of this data was to validate that the sampling had a representative number from each grade level and sex.

2. Students Who Participate in Activities - Any student who answered affirmatively to at least one item between items 27 - 69 (Iist of Current Activities) was entered into this category.

3. Students in Athletics only - only students who answered affirmatively to one item between numbers 27 - 
40 and negatively to items numbered 41 - 69 were included.

4. Non-Athletic Activities - Students who answered affirmatively to any item between $4 I-69$ and negatively to items 27 - 40 were included.

5. Students in Both Athletics and Non-Athletics Students who answered affirmatively to at least one item in numbers 27 - 40 and 41 - 69 were included.

6. Non-Participants - Students who answered negatively to items numbered $27-69$ were included.

7. Potential Dropouts - This category measured the number of students who fell into the construct established by Urdal. The students had to answer item to (Educational Level of the Father) with a 1, 2, or 3; item \#84 with a 5 (No Activities); and/or items \#27 - 69 (Activities) negatively. Because the language skill scores for the student sample were not available, academic grades were substituted on the assumptions of the Lichter study. This was item \#II and the answers were $5,6,7$ or 8 . The students also had to answer item \#12 with a 2, and/or item \#85 with a 1, 4 or 5 . Items \#12 and \#85 pertained to attitude.

8. Working Non-Participants - Students who answered Item \#7I with a 1 and/or item \#85 with a 2 were placed in this category. They also had to answer items \#27-69 with a 2 .

9. Bused Non-Participants - Students had to answer 
item \#8 with 1 , item \#73 with 1 , and items \#27-69 with 2.

10. Student Senate Members - An answer of $I$ to item \#23 signified membership and an answer of 2 to item \#23, non-membership.

11. Officers - An answer of 1 to item \#26 signified officer in an activity and an answer of 2 to item \#26 was a non-officer.

12. Socio-Economic Status - This was determined from the answers to item $\# 17$. This was a post-test entry. Depending upon the student's response, the answer was categorized into low, middle, and upper-middle classes. The Warner-Iunt criteria was applied for categorizing. Those students giving no response were deemed "unclassified."

Each of the forementioned categories was crossreferenced with other variable information in order to produce the desired Gestalt and profiles.

The students in categories $1-5$ were related to these variables:

\section{Item Number}

2

3

4

5

6 (Answer 1) and

7 (Answers 2 - 8)

8 (Answer 1)

9 (Answer 1)

\section{$\underline{\text { Variable }}$}

Age

S.ex

Grade level

Program track

Hours of work

Busing

Drive to school 
10 (Answer 1)

11

12

14

15

16 (Answers 2 or 3).

17 (Answers 1, 2 or 3)

21

22

71 (Answer 1)

73. (Answer 1)
Car ownership

Academic grades

School spirit

Ethnic background

Financial support

Self-support

Socio-economics

Source of friends

Satisfaction

Work conflicting with opportunity.

Busing conflicting with opportunity

Participation

Students who fell into Category 7, "Potential Dropouts," were cross-referenced with the additional variables in:

Item Number

13

19

20

$86-259$

\section{$\underline{\text { Variable }}$}

The first grade attended at that school

Days absent

Reason for absence

Preferences of activities

Students who fell into Category 8, "Working Non-. Participants," were related to item 7 , answers 2 - 8 (the number of hours worked.)

Students who fell into Category 9, "Bused NonParticipants," were cross-referenced with item 73.

Students who fell into Category 10, "Student Senate Members," were referenced to the variables: 
Item Number

2

3

4

5

11

14

15

17

18

24

25 $\underline{\text { Variable }}$

Age

Sex

Grade level

School program

Academic grades

Ethnic roots

Financial support

Socio-economic level

Educational level of the father

Perception of the senate Control of the senate

Students who fell into Category 1I, "Officers," were referenced with the variables of:

$\begin{array}{ll}2 & \text { Age } \\ 3 & \text { Sex } \\ 4 & \text { Grade } \\ 5 & \text { School program } \\ 17 & \text { Socio-economic level }\end{array}$

Stadents who fell into Category 12, "Socio-economic Status," were cross-referenced with item \#84, participation rates.

Method of Analysis: Second Student Questionnaire

In this questionnaire, the students were asked to give the same demographic data and to make activity choices. There were two parts to the activity choices, athletic activities and non-athletic activities. The students were asked to select only the three or four athletic activities 
and three or four non-athletic activities in which they would most like to be involved. This number was selected based on the work of Millholen with participation rates in schools. He found 3.1 activities per year to be an expected rate.

The responses for this questionnaire were again reduced to keypunch cards, computer processed, and divided into two categories, Potential Dropouts and Total Sample. The criteria for the "Potential Dropout" category were responses $5,6,7$ or 8 to item \#5 (academic grades); responses 1,2 , or 3 to item father); and response 2 to item $\frac{\|}{\pi} 8$ (attitude). While this combination is even less valid for determining dropouts than the one in the first questionnaire, it did encompass those who fell into the dropout pattern as well as others. The "Total sample" category determined how each item was rated by the entire sample population.

Teacher's Questionnaire

The teachers of each school were given a list of the same activity choices as the students. They were asked to check activities they had the skills to advise or coach or had an interest in. These choices were then manually cross-referenced with sex, age, teaching experience, degree held, department, type of college, and personal activity history in order to determine if there were any 
discernable patterns.

The activity choices of the students were then compared with the choices made by the teachers. The objective was to determine which activities had the greatest chance of success and if there were any discrepancies between student needs and interests and the faculty's ability to meet those needs and interests. 


\section{CHAPTER IV}

\section{RESULTS}

Each of the six objectives of this project is restated below, and how the objective was met is described briefly. Supporting Tables follow the findings.

Objective I To measure the Gestalt of student involvement in co-curricular activities.

Using the definition of Gestalt as the configurationism of the synchronic construct of the integration of the parts, in this case, the parts were the school, the co-curricular program and the students, a picture of how the three parts related to each other was generalized.

\section{S.t. Joseph}

In the findings:

- There was a relationship between the socioeconomic status of the students and participation (Table I)。

- There was a relationship between participation and attitude toward school (Table 2).

- There was a relationship between the activity opportunities provided by the school and the students' participation (Table 3 ).

- There was a relationship not only between academic grades and participation, but between

opportunity to participate. Work and busing conflicts with activities did reduce the numbers who participated (Table 3).

TABIE 1

SOCIO-ECONONIC STATUS OF THE STUDENTS AND PARTICIPATION

\begin{tabular}{llc}
\hline Total Sample & Participants & Non-Participants \\
\hline $26 \%$ Lower Class & $22 \%$ Lower Class & $49 \%$ Lower Class \\
$38 \%$ IIddle Class & $39 \%$ Middle Class & $35 \%$ Middle Class \\
$29 \%$ Upper-middle & $32 \%$ Upper-middle & Co\% Upper-middle \\
Class & Class & \\
\hline
\end{tabular}


academic grades and the type of activity the students participated in (Table 4).

- Students with higher academic grades tended to dominate non-athletic activities or to be involved in both athletic and non-athletic activities (Table 4 ).

- Students in athletics only tended to have lower academic grades (Table 4 ).

- Students of Middle and Upper-middle classes tended to dominate disproportionally the leadership position in activities and membership in activities (Table 5 ).

- Program track was related to both leadership and participation (Table 6).

- Participation in activities did not depend on ethnic background (Table 7).

- Participation in activities did depend on the opportunity to participate. Work and busing conflicts with activities did reduce the numbers who participated (Table 3).

TABLE 1

SOCIO-ECONONIC STATUS OF THE STUDENTS AND PARTICIPATION

\begin{tabular}{lll} 
Total Sample & Participants & Non-Participants \\
\hline $26 \%$ Lower Class & 22\% Iower Class & $49 \%$ Lower Class \\
$38 \%$ Nidde Class & $39 \%$ Niddle Class & $35 \%$ Middle Class \\
$29 \%$ Upper-midde & $32 \%$ Upper-middle & 10\% Upper-middle \\
Class & Class & Class
\end{tabular}

$7 \%$ Unclassified 
TABLE 2

ATTITUDE AND PARTICIPATION

\begin{tabular}{lll}
\hline Total Sample & Participants & Non-Participants \\
\hline $75 \%$ positive & $82 \%$ positive & $21 \%$ positive \\
\hline
\end{tabular}

TABLE 3

OPPORTUNITY AND PARTICIPATION

\begin{tabular}{lc} 
Total Sample & Non-Participants \\
\hline $30 \%$ lacked time to be & $19 \%$ claimed lack of trans- \\
in school activities & portation to be in activities \\
$11 \%$ did not have trans- & $58 \%$ claimed work conflicted \\
portation to be in & with school activities \\
school activities & $95 \%$ of working non-partici- \\
& pants claimed conflict with \\
& school activities \\
& $100 \%$ of bused non-participants \\
& claimed lack of transporta- \\
& tion to be in activities
\end{tabular}

TABLE 4

RELATIONSHIP BETWEEN PARTICIPATION AND ACADEMICS

\section{Participants}

15\% Mostly A's

$27 \%$ Half $A^{\prime} s /$ Half $B^{\prime} s$

$24 \%$ Mostly B's

$24 \%$ Half B's/Half C's

$7 \%$ Mostly C's

$2 \%$ Half C's/Half D's
Non-Participants

6\% Mostly A's

15\% Half A's/Half $B^{\prime} s$

31\% Mostly B's

$20 \%$ Half B's/Half C's

$17 \%$ Mostiy C's

$6 \%$ Half $C^{\prime} s / H a l f ~ D^{\prime} s$

4\% Mostly D's 
TABLE 4 (continued)

S.tudents in Athletics OnIy

$5 \%$ Mostiy A's

$13 \%$ Half $A^{\prime}$ 's/half $B^{\prime} s$

41\% Mostly B's

$32 \% \mathrm{Half} \mathrm{B}^{\prime} \mathrm{s} / \mathrm{half} \mathrm{C}^{\prime} \mathrm{s}$

$8 \%$ Mostly C's

3\% Below C's

Students in Non-Athletics Only

$16 \%$ Mostly A's

$32 \%$ Half A's/half B's

$28 \%$ Mostly B's

15\% Half B's/half C's

$7 \%$ Mostly C's

$2 \%$ Half C's/half D's

Students in Both Athletics and lon-Ahletics

$18 \%$ Mostly A's

$28 \%$ Half A's/half $\bar{B}^{\prime} \mathrm{s}$

17\% Mostly B's

29\% Half B's/half C's

$8 \%$ Mostiy C's

2\% Half C's/half D's

\section{TABLE 5}

LEADERSHIP AND NEMBERSHIP

\begin{tabular}{lll} 
Total Sample & Officers & Senate Members \\
\hline $26 \%$ Lower Class & $15 \%$ Lower Class & $9 \%$ Iower Class \\
$38 \%$ Middle Class & $33 \%$ Middle Class & $45 \%$ Middle Class \\
$29 \%$ Upper-middle & $44 \%$ Upper-middle & $45 \%$ Upper- \\
Class & Class & Middle Class
\end{tabular}


TAELE 6

REIATIONSHIP OF PROGRAM TRACK TO

LEADERSHIP AND PARTICIPATION

\begin{tabular}{ll}
\hline Total Sample & Participants \\
\hline $76 \%$ College Prep & $81 \%$ College Prep \\
$13 \%$ Vocational & $10 \%$ Vocational \\
$10 \%$ Business & $8 \%$ Business \\
& $\frac{\text { Senate Members }}{95 \% \text { College Prep }}$ \\
& $5 \%$ Business \\
& $\frac{0 \text { fficers in Activities }}{81 \% \text { College Prep }}$ \\
& $10 \%$ Vocational \\
& $6 \%$ Business \\
\hline
\end{tabular}

\section{TABLE 7}

ETHNIC BACKGROUND AND PARTICIPATION

\begin{tabular}{lll}
\hline Total Sample & Participants & Non-Participants \\
\hline $62 \% \mathrm{~N}$. European & $67 \% \mathrm{~N}$. European & $38 \% \mathrm{~N}$. European \\
$8 \% \mathrm{~S}$. European & $7 \% \mathrm{~S}$. European & $13 \% \mathrm{~S}$. European \\
$5 \%$ Amer. Indian & $5 \%$ Amer. Indian & $8 \%$ Amer. Indian \\
$1 \% \mathrm{BIack}$ & $1 \% \mathrm{BIack}$ & $0 \%$ BIack \\
$1 \%$ Chicano & $1 \%$ Chicano & $0 \%$ Chicano \\
$20 \%$ Other & $18 \%$ Other & $31 \%$ Other \\
& & $6 \%$ No response \\
\hline
\end{tabular}




\section{Bridgman}

In the findings:

- There was no apparent relationship between socio-economic status and participation (Table 8).

- There was a relationship between attitude and participation (Table 9).

- There was a relationship between academic grades and participation. Students involved in nonathletic and both non-athletic and athletic activities tended to have higher academic grades than students in athletics only (Table 10).

- Student leadership was not related to socioeconomic status (Table 11).

- Participation was not related to program track (Table 12).

TABLE 8

SOCIO-ECONOMIC STATUS OF THE STUDENTS AND PARTICIPATION

Total Sample

$55 \%$ Lower Class $26 \%$ Middle Class $6 \%$ Upper-middle class 11\% Unclassified
Participants

$52 \%$ Lower Class $28 \%$ Middle Class $7 \%$ Upper-middle class 11\% Unclassified
Non-Participants

$67 \%$ Lower Class $17 \%$ Middle Class $3 \%$ Upper-middle class 
TABLE 9

ATTITUDE AND PARTICIPATION

\begin{tabular}{lll}
\hline Total Sample & Participants & Non-Participants \\
\hline $87 \%$ positive & $82 \%$ positive & $57 \%$ negative \\
\hline
\end{tabular}

TABLE 10

REIATIONSHIP BETWEEN PARTICIPATION AND ACADEMICS

Participants

16\% Niostly A's

$24 \%$ Half A's/half B's

$17 \%$ IIostly B's

$27 \%$ Half B's/half C's

$8 \%$ Inostiy C's

$6 \%$ Half C's/half $D^{\prime}$ s

I\% Mostly D's
Non-Participants

$0 \%$ Mostly A's

II\% Half A's/half B's

$4 \%$ I'ostly B's

$29 \%$ Half $B^{\prime} s / h a l f C^{\prime} s$

$29 \%$ Mostly C's

$14 \%$ Half C's/half D's

$14 \%$ Mostly D's

Students in Athletics only

$13 \%$ Mostly A's

$17 \%$ Half A's/ half B's

$17 \%$ Mostly B's

$30 \%$ Half $B^{\prime} \mathrm{s} / \mathrm{half} \mathrm{C}^{\prime} \mathrm{s}$

13\% Nostly C's

$4 \%$ Half $C^{\prime} s / h a l f D^{\prime} s$

$4 \%$ Mostly D's

S.tudents in Non-Athletics Only

11\% Mostiy A's

$18 \%$ Half $A^{\prime} s /$ half $B^{\prime} s$

$22 \%$ Mostly B's

29\% Half B's/half C's

3\% Hostiy C's

II\% Half C's/half D's 
TABLE 10 (continued)

Students in Both Athletics and Non-Athletics

$18 \%$ Mostly A's

$27 \%$ Half A's/half $B^{\prime}$ s

15\% Mostly B's

$25 \%$ Half B's/half C's

8\% Mostly C's

$4 \%$ Half C's/half D's

TABIE 11

LEADERSHIP AND SOCIAI STATUS

\begin{tabular}{lll} 
Total Sample & Officers & Senate liembers \\
\hline $55 \%$ Lower Class & $45 \%$ Lower Class & $33 \%$ Iower Class \\
$26 \%$ Viddde Class & $30 \%$ Middle Class & $33 \%$ Niddle Class \\
$6 \%$ Upper-midde & $10 \%$ Upper-middle & $16 \%$ Upper-midale \\
Class & Class & Class \\
$11 \%$ Unclassified & $15 \%$ Unclassified & $16 \%$ Unclassified \\
\hline
\end{tabular}

TABLE 12

PARTICIPATION AND PROGRAM TRACK

Total Sample Participants

Non-Participants

$34 \%$ College Prep

$37 \%$ College Prep

14\% College Prep

43\% Vocational

$39 \%$ Vocational

$14 \%$ Business

$13 \%$ Business

$64 \%$ Vocational

17\% Business 
Objective 2 To develop a profile of the students involved and not involved in activities with regard to certain demographic characteristics. S.t. Joseph

The students who were participants in activities presented a generalized profile distinguishable from students who did not participate. The generalized participant in St. Joseph High School was predominately Northern European in heritage, came from a Middle to Upper-middle class family, and was financially dependent on the family. He was in the college prep program, had a positive school spirit, was in two to three or more activities per year, and achieved a high percentage of personal satisfaction from school. (Table 13).

The generalized non-participant had an ethnic background not predominately Northern European, came from a family of lower socio-economic class, and had a job. He had less of a tendency to be in the college prep program, had no school spirit, had a higher degree of work conflict with activity opportunities and achieved most of his personal satisfaction out of school (Table 14).

The category of prime interest in this study was the potential dropout. Using the criteria described in preceding chapters to identify him, this test found that St. Joseph High School had a potential dropout rate of $3.2 \%$ or 44 students. The official posted dropout rate was $1.9 \%$ (Guidance Department). 
The generalized profile of the potential dropout in St. Joseph High School was that the student came from the lower socio-economic class and did not work. He was in the 9 th or 1 th grade, had little satisfaction in school, had little involvement in school, and had friendships that were made out of school (Table 15).

\section{TABLE 13}

PROFIIE OF PARTICIPANTS

Participants

$81 \%$ College prep program

$82 \%$ Positive school spirit

$71 \%$ were in two to three or more activities per year

$67 \%$ Northern European background

$78 \%$ were financially dependent on the family

$71 \%$ Middle to Upper-midale class

$31 \%$ said that school activities provided their most personal satisfaction

TABLE 14

PROFILE OF NON-PARTICIPANTS

Non-Participants

$48 \%$ College prep program

$27 \%$ Vocational program

$23 \%$ Business program

$56 \%$ had a job

$58 \%$ had a work conflict with school activities

79\% Negative school spirit

49\% Lower Class

$35 \%$ Middle Class

$31 \%$ Northern European background

$98 \%$ personal satisfaction from non-school activities 
TABLE 15

PROFIIE OF POTENTIAI DROPOUTS'

Potential Dropouts

$50 \%$ 9th grade level

$50 \%$ lith grade level

$60 \%$ did not work

$80 \%$ Lower class

$0 \%$ personal satisfaction from school activities

$60 \%$ of all friends were made out of school

\section{Bridgman}

The generalized participant in Bridgman High School was predominately European in ethnic background, came from the lower socio-economic class, and had a parttime job. He was in either a college prep or vocational program, had a positive school spirit, was in two to three or more activities, and achieved the majority of personal satisfaction in non-school activities (Table 16).

The generalized non-participant was predominately male, came from the lower socio-economic class, and did not work. He was in the vocational program, had a negative school spirit, and achieved no personal satisfaction from school or school activities ( $\mathrm{T}_{\mathrm{a}} \mathrm{ble}$ 17).

The generalized potential dropout derived by the Urdal criteria equaled $4.3 \%$ of the sample population or 15 students in the school ( 350 total population $x 4.3 \%$ ). 
The rate of $4.3 \%$ was assumed valid on the grounds that the official posted rate was between $4 \%$ and $4.5 \%$ (Guidance Department).

The generalized profile of the potential dropout in Bridgman High School was that the student was male, did not know his ethnic background, came from the lower socioeconomic class, and did not work. He was in grades 9 and 11, was in the vocational program, had a negative school spirit, and had a negative attitude toward school and school activities (Table 18).

\section{TABLE 16}

PROFIII OF PARTICIPANTS

Participants

$37 \%$ College prep program

$39 \%$ Vocational program

$51 \%$ had at least a parttime job

$82 \%$ Positive school spirit

$64 \%$ were in two to three or more school activities per year 60\% Northern European background

$52 \%$ Lower class

$74 \%$ personal satisfaction from non-school activities 
TABLE 17

PROFILE OF NON-PARTICIPANTS

Non-Participants

$75 \%$ Viale

$64 \%$ Vocational program

$61 \%$ did not work

$57 \%$ negative school spirit

$0 \%$ personal satisfaction from school activities

69\% Lower class

\section{TABLE 18}

PROFILE OF POTENTIAI DROPOUTS

\section{Potential Dropouts}

$100 \%$ Male

$100 \% 9$ th or 11th grade

$85 \%$ Vocational program

$72 \%$ did not work

$71 \%$ negative school spirit

$85 \%$ Lower class

$0 \%$ personal satisfaction from school activities

$71 \%$ did not like school activities

$71 \%$ felt they had better things to do

Objective 3 To determine from the students themselves alternative programs to better meet their needs and interests.

The results of this objective were non-conclusive. The students were given three lists of activities: one 
was current activities, one was alternatives, and the third was a fill-in for the students to suggest activities. Response was good. The only discernable pattern was in the types of activities chosen by the total sample and the potential dropout category. The potential dropouts tended to choose activities not normally associated with school programs (Tables 19 and 20)。

\section{TABLE 19}

SAMPLE OF ST. JOSEPH HIGH SCHOOI ACTIVITY CHOICES FROM THE FIRST QUESTIONNAIRE

\begin{tabular}{lll}
\hline Potential Dropouts & $\begin{array}{l}\text { Activity } \\
\text { Choices* }\end{array}$ & Total Sample \\
\hline $70 \%$ & Automobiles & $29 \%$ \\
$60 \%$ & Bowling & $43 \%$ \\
$50 \%$ & Karate & $21 \%$ \\
$50 \%$ & Archery & $23 \%$ \\
$40 \%$ & Volleyball & $47 \%$ \\
$40 \%$ & Judo & $20 \%$ \\
$40 \%$ & Hunting & $25 \%$ \\
$40 \%$ & Fishing & $34 \%$ \\
$20 \%$ & Basketball & $45 \%$ \\
$0 \%$ & Tennis & $44 \%$ \\
$30 \%$ & Skiing & $49 \%$ \\
$*$ & Canoeing & $75 \%$ \\
See pages 65 and 81, Appendix A. & \\
\hline
\end{tabular}


TABLE 20

SAMPLE OF BRIDGMAN HIGH SCHOOL

ACTIVITY CHOICES FROM THE FIRST QUESTIONNAIRE

\begin{tabular}{lll}
\hline \hline & & \\
\hline Potential Dropouts & Activity & Choices* \\
\hline $86 \%$ & Pool & $40 \%$ \\
$71 \%$ & Hunting & $41 \%$ \\
$71 \%$ & Trapping & $24 \%$ \\
$71 \%$ & Canoeing & $60 \%$ \\
$57 \%$ & Football & $31 \%$ \\
$57 \%$ & Baseball & $40 \%$ \\
$57 \%$ & Ping Pong & $37 \%$ \\
$57 \%$ & Card Games & $35 \%$ \\
$42 \%$ & Basketball & $45 \%$ \\
$42 \%$ & Forestry & $34 \%$ \\
$42 \%$ & Conservation & $22 \%$ \\
* See pages 99 and 115 for complete list. \\
\hline
\end{tabular}

Objective 4. To determine by objective methods, from existing and alternative programs, activities that interest the potential dropout and the greatest number of students.

This was the purpose of the second questionnaire (See Appendix E). The choices made on the first questionnaire that had more than a $14 \%$ response (See Maxey) were included in the questionnaire. The result was that there was a discernable difference between the activity preferences of the total student sample and the potential dropouts. In many cases, there appeared to be more total student interest in alternative activities than in existing ones. This trend held through both schools. 
This trend was noted by comparing total sample responses in both questionnaires (Tables 21 and 22).

TABLF 21

S.T. JOSEPH HIGH SCHOOI SECOND QUESTIONNAIRF

ITENS WITH HIGHEST PERCENTAGE OF RESPONSE

\begin{tabular}{lll}
\hline \hline Potential Dropouts & Activities & Total Sample \\
\hline $54 \%$ & Pool & $20 \%$ \\
$46 \%$ & Shooting/Sket & $13 \%$ \\
$46 \%$ & Ivisic Lessons & $26 \%$ \\
$46 \%$ & Motorcycle Club & $15 \%$ \\
$46 \%$ & Stereo Club & $20 \%$ \\
$46 \%$ & Hunting/Fisning & $16 \%$ \\
$39 \%$ & Archery & $14 \%$ \\
$39 \%$ & Camping/Hiking & $35 \%$ \\
$39 \%$ & Nonsense Activities & $46 \%$ \\
$31 \%$ & Ping Pong & $24 \%$ \\
$31 \%$ & Judo & $10 \%$ \\
$31 \%$ & Karate & \\
$*$ See pages 93 and 94 for complete Iist. & \\
\hline
\end{tabular}


TABLE 22

BRIDGITAN HIGH SCHOOI SECOND QUESTIONNAIRF

ITEMS WITH HIGHEST PERCENTAGE OF RESPONSE

\begin{tabular}{lll}
\hline Potential Dropouts & Activities & \\
\hline $61 \%$ & Ping Pong & Total Sample \\
$61 \%$ & Hunting/Fishing & $25 \%$ \\
$46 \%$ & Karate & $32 \%$ \\
$38 \%$ & Pool & $23 \%$ \\
$38 \%$ & Shooting/Sikeet & $26 \%$ \\
$38 \%$ & Judo & $19 \%$ \\
$38 \%$ & Auto Club & $24 \%$ \\
$30 \%$ & Football & $20 \%$ \\
$30 \%$ & Canoeing & $36 \%$ \\
$30 \%$ & Forestry/ & \\
$30 \%$ & Conservation & $24 \%$ \\
$30 \%$ & Camping/Hiking & $25 \%$ \\
$30 \%$ & Rock Band & $25 \%$ \\
$*$ See pages 127 and 128 for complete Iist. & \\
\hline
\end{tabular}

Objective 5 To determine if the faculty had the interest and skills needed to effectively run alternative programs。

There was a $60 \%$ response out of 84 teachers in St. Joseph and a 70\% response out of 24 teachers in Bridgman. The first part was to determine if there would be a relationship between the demographic variables asked and activity choices. There were no discernable patterns observable between activity choices made and the variables. The only noticeable pattern was between the number of activities a teacher participated in while in high school 
or college and the number of choices made on the activities Iist. The general pattern was the greater the number of past activities, the greater the number of activities checked on the activities list of the test. This was an observed pattern only and not shown in this report.

The total number of teachers who checked any particular activity was compared to the percentage of students who had chosen that activity. The findings were that in most cases, at least one teacher expressed an interest in the activities chosen by the dropouts and the total student sample. In a few cases, (Example: Judo and Karate) the student interest was high but there was no teacher interest (Tables 23 and 24)。

TABIE 23

ACTIVITY CHOICES OF ST. JOSEPH HIGH SCHOOL TEACHERS BY RANKING COIPARED WITH STUDENT CHOICES

\begin{tabular}{|c|c|c|c|}
\hline Activities & $\begin{array}{l}\text { Tiumber of } \\
\text { Teachers }\end{array}$ & $\begin{array}{l}\text { Percentage oI } \\
\text { Potential Dropouts }\end{array}$ & $\begin{array}{l}\text { Percentage oI } \\
\text { Total Sample }\end{array}$ \\
\hline \multicolumn{4}{|l|}{ Nonsense } \\
\hline $\begin{array}{l}\text { Activities } \\
\text { Snow Skijng }\end{array}$ & 13 & 39 & $\begin{array}{l}46 \\
38\end{array}$ \\
\hline & 13 & & \\
\hline \multicolumn{4}{|l|}{ Basketball } \\
\hline Team & 11 & 8 & 21 \\
\hline Golf & 10 & 8 & 9 \\
\hline Canoeing & 10 & 15 & 44 \\
\hline Youth Problen & ms 10 & 8 & 12 \\
\hline \multicolumn{4}{|c|}{ Boating and } \\
\hline Sailing & 9 & 0 & 31 \\
\hline Bike Club & 9 & 0 & 24 \\
\hline \multicolumn{4}{|l|}{ Track and } \\
\hline Field & 8 & 8 & 22 \\
\hline
\end{tabular}


TABLE 23 (continued)

\begin{tabular}{|c|c|c|c|}
\hline Activities & $\begin{array}{l}\text { Number o } \\
\text { Teachers }\end{array}$ & $\begin{array}{l}\text { Percentage of } \\
\text { Potential Dropouts }\end{array}$ & $\begin{array}{l}\text { Percentage of } \\
\text { Total Sample } \\
\end{array}$ \\
\hline $\begin{array}{l}\text { Drama } \\
\text { Hunting and }\end{array}$ & 8 & 0 & 11 \\
\hline Fishing & 8 & 46 & 16 \\
\hline $\begin{array}{l}\text { Tennis } \\
\text { Girls Volley- }\end{array}$ & 7 & 0 & 20 \\
\hline $\begin{array}{l}\text { ball } \\
\text { Camping and }\end{array}$ & 7 & 16 & 26 \\
\hline Hiking & 7 & 39 & 35 \\
\hline $\begin{array}{l}\text { Math Club } \\
\text { Football }\end{array}$ & 7 & 0 & 5 \\
\hline Intramurals & 6 & 0 & 8 \\
\hline $\begin{array}{l}\text { Baseball Team } \\
\text { Baseball }\end{array}$ & 6 & 8 & 14 \\
\hline Intramurals & 6 & 0 & 11 \\
\hline $\begin{array}{l}\text { Swimming } \\
\text { Intramurals }\end{array}$ & 6 & 0 & 15 \\
\hline $\begin{array}{l}\text { Tennis } \\
\text { Intramurals }\end{array}$ & 6 & 8 & 21 \\
\hline $\begin{array}{l}\text { Sihooting and } \\
\text { Skeet }\end{array}$ & & & \\
\hline Swimming and & 6 & 40 & 13 \\
\hline $\begin{array}{l}\text { Diving Team } \\
\text { Gymnastics }\end{array}$ & $\begin{array}{l}5 \\
5\end{array}$ & $\begin{array}{l}0 \\
8\end{array}$ & $\begin{array}{l}16 \\
18\end{array}$ \\
\hline Water Skiing & 5 & 23 & 34 \\
\hline Racquetball & 5 & 0 & 7 \\
\hline Girls Softball & 5 & 15 & 19 \\
\hline $\begin{array}{l}\text { Photography } \\
\text { Cinema }\end{array}$ & $\begin{array}{l}5 \\
5\end{array}$ & $\begin{array}{r}23 \\
0\end{array}$ & $\begin{array}{l}25 \\
72\end{array}$ \\
\hline Handcrafts & 5 & 16 & $\begin{array}{r}+2 \\
6\end{array}$ \\
\hline Music Club & 5 & 8 & 13 \\
\hline Law and Society & 5 & 8 & 7 \\
\hline Newspaper & 5 & 0 & 10 \\
\hline $\begin{array}{l}\text { Yearbook } \\
\text { Class }\end{array}$ & 5 & 0 & 17 \\
\hline Organizations & 5 & 0 & 5 \\
\hline Cheerleaders & 5 & 0 & 6 \\
\hline Cross Country & 4 & 0 & 3 \\
\hline Handball & 4 & 8 & 7 \\
\hline Roller Skating & 4 & 16 & 12 \\
\hline $\begin{array}{l}\text { Ice and Figure } \\
\text { Skating }\end{array}$ & 4 & 0 & 11 \\
\hline Summer Stock & 4 & 0 & 5 \\
\hline Debate Team & 4 & 0 & 7 \\
\hline Working & 4 & 8 & 5 \\
\hline
\end{tabular}


TABLE 23 (continued)

\begin{tabular}{|c|c|c|c|}
\hline Activities & $\begin{array}{l}\text { umber of } \\
\text { eachers }\end{array}$ & $\begin{array}{l}\text { Percentage of } \\
\text { Potential Dropouts }\end{array}$ & $\begin{array}{l}\text { Percentage of } \\
\text { Total Sample } \\
\end{array}$ \\
\hline Art Club & 4 & 0 & 12 \\
\hline Cards and Games & 4 & 8 & 5 \\
\hline \multicolumn{4}{|l|}{ Space and } \\
\hline Astronomy & 4 & 8 & 5 \\
\hline Girls Football & 3 & 0 & 10 \\
\hline Archery & 3 & 39 & 14 \\
\hline Ping Pong & 3 & 31 & 24 \\
\hline Boys Volleyball & 3 & 0 & 6 \\
\hline Badminton & 3 & 15 & 20 \\
\hline \multicolumn{4}{|l|}{ Cooking and } \\
\hline Sewing & 3 & 0 & 7 \\
\hline Auto Club & 3 & 23 & 6 \\
\hline Animal Care & 3 & 0 & 15 \\
\hline Business Club & 3 & 0 & 5 \\
\hline \multicolumn{4}{|l|}{ Foreign Ianguage } \\
\hline Club & 3 & 0 & 8 \\
\hline Choral & 3 & 0 & 16 \\
\hline Honeybears & 3 & 0 & 2 \\
\hline Pool & 2 & 54 & 20 \\
\hline Weightlifting & 2 & 23 & 8 \\
\hline Wrestling & 2 & 0 & 4 \\
\hline Dance Class. & 2 & 8 & 7 \\
\hline Music Lessons & 2 & 8 & 15 \\
\hline Plant Care & 2 & 8 & II \\
\hline History Club & 2 & 0 & 4 \\
\hline Band & 2 & 0 & 15 \\
\hline Ice Hockey & 1 & 8 & 4 \\
\hline Soccor & $\bar{I}$ & 8 & 9 \\
\hline Boys Softball & 1 & 8 & 8 \\
\hline Boxing & 1 & 8 & 7 \\
\hline Rock Band & 1 & 46 & 26 \\
\hline Stereo Club & $\overline{1}$ & 46 & 20 \\
\hline Biology Club & $I$ & 0 & 3 \\
\hline Photography Club & 1 & 0 & 7 \\
\hline Judo & 0 & 31 & 10 \\
\hline Karate & 0 & 31 & 12 \\
\hline Motorcycle Club & 0 & 46 & 15 \\
\hline Model Craft & 0 & 0 & 2 \\
\hline \multicolumn{4}{|l|}{ Forestry and } \\
\hline Conservation & 0 & 16 & 14 \\
\hline Radio Club & 0 & 16 & 7 \\
\hline Sociology Club & 0 & 0 & 5 \\
\hline Supernatural & 0 & 23 & 16 \\
\hline English Club & 0 & 0 & 2 \\
\hline
\end{tabular}


TABLE 24

- ACTIVITY CHOICES OF BRIDGMAN HIGH SCHOOL TEACHERS BY RANKING CONPARED WITH STUDENT CHOICES

\begin{tabular}{|c|c|c|c|}
\hline Activities & $\begin{array}{l}\text { Number of } \\
\text { Teachers }\end{array}$ & $\begin{array}{l}\text { Percentage of } \\
\text { Potential Dropouts }\end{array}$ & $\begin{array}{l}\text { Percentage of } \\
\text { Total Sample }\end{array}$ \\
\hline $\begin{array}{l}\text { Canoeing } \\
\text { Baseball Team } \\
\text { Boys Volleyball } \\
\text { Bowling } \\
\text { Softball }\end{array}$ & $\begin{array}{l}5 \\
5 \\
4 \\
4 \\
4\end{array}$ & $\begin{array}{r}30 \\
15 \\
7 \\
7 \\
15\end{array}$ & $\begin{array}{l}36 \\
26 \\
11 \\
32 \\
18\end{array}$ \\
\hline \multicolumn{4}{|l|}{ Forestry and } \\
\hline Conservation & 4 & 30 & 16 \\
\hline $\begin{array}{l}\text { Youth Problems } \\
\text { Swimming and }\end{array}$ & 4 & 7 & 12 \\
\hline \multicolumn{4}{|l|}{ Swimming and } \\
\hline $\begin{array}{l}\text { Diving Rec. } \\
\text { Tennis Team }\end{array}$ & $\begin{array}{l}3 \\
3\end{array}$ & 46 & $\begin{array}{l}18 \\
28\end{array}$ \\
\hline \multicolumn{4}{|l|}{$\begin{array}{l}\text { Tennis Team } \\
\text { Tennis }\end{array}$} \\
\hline $\begin{array}{l}\text { Recreation } \\
\text { Golt }\end{array}$ & $\begin{array}{l}3 \\
3\end{array}$ & $\begin{array}{r}7 \\
15\end{array}$ & $\begin{array}{l}29 \\
12\end{array}$ \\
\hline $\begin{array}{l}\text { Hunting and } \\
\text { Fishing }\end{array}$ & 3 & 61 & 32 \\
\hline \multicolumn{4}{|l|}{ Niusic } \\
\hline $\begin{array}{l}\text { Appreciation } \\
\text { Biking }\end{array}$ & $\begin{array}{l}3 \\
3\end{array}$ & $\begin{array}{l}7 \\
7\end{array}$ & $\begin{array}{l}11 \\
21\end{array}$ \\
\hline \multicolumn{4}{|l|}{ Camping and } \\
\hline \multicolumn{4}{|l|}{ Nonsense } \\
\hline $\begin{array}{l}\text { Activities } \\
\text { Football Team }\end{array}$ & $\begin{array}{l}3 \\
2\end{array}$ & $\begin{array}{l}30 \\
30\end{array}$ & $\begin{array}{l}25 \\
20\end{array}$ \\
\hline Baseball Team & 2 & 15 & 20 \\
\hline Badminton & 2 & 0 & 17 \\
\hline Wrestling & 2 & 15 & 9 \\
\hline CB Radio & 2 & 23 & 19 \\
\hline Hand Crafts & 2 & 7 & 16 \\
\hline Biology Club & 2 & 0 & 8 \\
\hline Auto Club & 2 & 38 & 24 \\
\hline Theatre & 2 & 0 & 11 \\
\hline Geology & 2 & 0 & 2 \\
\hline Photography & 2 & 15 & 9 \\
\hline Band & 2 & 7 & 11 \\
\hline \multicolumn{4}{|l|}{ Football } \\
\hline Intramurals & 1 & 7 & 3 \\
\hline $\begin{array}{l}\text { Girlsamurals } \\
\text { Birls Football } \\
\text { Baseball }\end{array}$ & 1 & 0 & 17 \\
\hline Intramurals & 1 & 30 & 10 \\
\hline
\end{tabular}


TABLE 24 (continued)

\begin{tabular}{|c|c|c|c|}
\hline Activities & $\begin{array}{l}\text { Number of } \\
\text { Teachers }\end{array}$ & $\begin{array}{l}\text { Percentage of } \\
\text { Potential Dropouts }\end{array}$ & $\begin{array}{l}\text { Percentage of } \\
\text { Total Sample }\end{array}$ \\
\hline \multicolumn{4}{|l|}{ Swimming and } \\
\hline Diving Team & 1 & 20 & 20 \\
\hline Gymnastics & 1 & 0 & 12 \\
\hline Ping Pong & 7 & 61 & 25 \\
\hline \\
\hline Skeet & 1 & 38 & 19 \\
\hline Soccor & 1 & 7 & 28 \\
\hline Girls Volleyball & 11 & 0 & 18 \\
\hline Snow Skiing & 1 & 15 & 17 \\
\hline Water Skiing & 1 & 15 & 29 \\
\hline \multicolumn{4}{|l|}{ Ice and Figure } \\
\hline Skating & $I$ & 7 & 11 \\
\hline Weightlifting & 1 & 15 & $\frac{1}{6}$ \\
\hline Art club & $I$ & 7 & 11 \\
\hline Plant Care & 1 & 7 & 8 \\
\hline Business CIub & 1 & 0 & 9 \\
\hline Education CIub & 1 & 0 & 8 \\
\hline Sociology Club & 1 & 0 & 6 \\
\hline Supernatural & $\bar{I}$ & 1 & 7 \\
\hline Chemistry Club & 1 & 0 & 7 \\
\hline \multicolumn{4}{|l|}{ Baking and } \\
\hline Cooking & 1 & 7 & 8 \\
\hline \multicolumn{4}{|l|}{ Foreign Ianguage } \\
\hline club & 1 & 0 & 7 \\
\hline Astrology & 1 & 0 & 3 \\
\hline Choral & 1 & 15 & 9 \\
\hline Newspaper & 1 & 0 & 8 \\
\hline Yearbook & 1 & 0 & 9 \\
\hline \multicolumn{4}{|l|}{ Class Organiza- } \\
\hline tions & 1 & 0 & 3 \\
\hline GAA & $I$ & 7 & 9 \\
\hline \multicolumn{4}{|l|}{ Baseball } \\
\hline Intramurals & 0 & 15 & 14 \\
\hline Track and Field & 0 & 30 & 20 \\
\hline HandbalI & 0 & 15 & 9 \\
\hline Field Hockey & 0 & 7 & 6 \\
\hline Judo & 0 & 38 & 18 \\
\hline Karate & 0 & 46 & 23 \\
\hline Ice Hockey & 0 & 7 & 6 \\
\hline Cross Country & 0 & 0 & 7 \\
\hline Law and society & 0 & 23 & 13 \\
\hline Games & 0 & 7 & 9 \\
\hline Philosophy Club & 0 & 0 & 3 \\
\hline Gunsmithing & 0 & 7 & 12 \\
\hline
\end{tabular}


TABLE 24 (continued)

\begin{tabular}{lccc}
\hline & $\begin{array}{c}\text { Number of } \\
\text { Activities } \\
\text { Teachers }\end{array}$ & $\begin{array}{c}\text { Percentage of } \\
\text { Potential Dropouts }\end{array}$ & $\begin{array}{c}\text { Percentage of } \\
\text { Total Sample }\end{array}$ \\
\hline Music Lessons & 0 & 0 & 13 \\
Motorcycle Club & 0 & 23 & 26 \\
Rock Band & 0 & 30 & 25 \\
Woodcrafting & 0 & 7 & 9 \\
Cinema Club & 0 & 7 & 10 \\
Dance Class & 0 & 0 & 13 \\
Debate Team & 0 & 0 & 10 \\
FHA & 0 & 7 & 1 \\
RViS & 0 & 7 & 6 \\
Cheerleaders & 0 & 0 & 6 \\
\hline
\end{tabular}

Objective 6 To develop a standardized instrument usable by school administrators.

This questionnaire project was constructed on the basis of past research into the area of student cocurricular interests and participation patterns. By the comparison of the results of this study with the materials mentioned in the Review of Iiterature, it was found that many of the patterns found by previous researchers also appeared in the findings of this study. For example, there is a relationship between participation and socio-economic status (Gordon). See Tables 1 and 8. Students do not participate in activities because their needs and interests are not met (Jacobson). See objectives 3 through 5 in this chapter. Schools are a prime source of friends(Jacobson). See Table 25 on the following page. 
TABLE 25

SOURCES OF FRIENDS

\begin{tabular}{lll}
\hline \hline St。 Joseph & Sources & Bridgman \\
\hline $84 \%$ & School & $89 \%$ \\
$2 \%$ & Family & $2 \%$ \\
$4 \%$ & Church & $2 \frac{1}{2} \%$ \\
$1 \%$ & Work & $0 \%$ \\
$5 \%$ & Neighborhood & $3 \%$ \\
$4 \%$ & Other & $2 \frac{1}{2} \%$ \\
\hline
\end{tabular}

Extra-curricular activities are the greatest source of personal satisfaction for students who participate. (Jacobson). See Table 26 below.

TABLE 26

SOURCES OF PERSONAL SATISFACTION FOR PARTICIPATING STUDENTS

\begin{tabular}{lll} 
St. Joseph & Sources & Bridgman \\
\hline $3 \%$ & Class Work & $2 \%$ \\
$29 \%$ & School Activities & $24 \%$ \\
$18 \%$ & Out of School & $12 \%$ \\
$6 \%$ & Activities & $8 \%$ \\
$10 \%$ & Work & $12 \%$ \\
$28 \%$ & Hobbies & $36 \%$ \\
$0 \%$ & Unplanned & $3 \%$ \\
\hline
\end{tabular}


Work commitments and transportation are influencers in participation in activities (Frederick) (Table 27)。

\section{TABLE 27}

WORK COMMITNENTS, AND TRANSPORTATION

S.t. Joseph

$58 \%$ of working non-participants claimed work conflicted with their opportunity to participate

19\% of the non-participants claimed busing interfered with their opportunity to particinate

Bridgman

$32 \%$ of working non-participants claimed work conflicted with their opportunity to participate

10\% of the non-participants claimed busing interfered with their opportunity to participate

There is a relationship between attitude toward school and participation (Sherrodd). See Objective I, Tables 2 and 9.

When the dropout identifiers were applied to the sample used in the study, the results were a match in Bridgman, $4.3 \%$ vs $4.5 \%$, but a large difference in st. Joseph, $3.2 \%$ vs $1.9 \%$ The validity of this questionnaire, while not proven, did indicate a certain degree of reliability.

Since this questionnaire was able to be keypunched and computer analyzed, the format and procedures are 
usable on a generalized basis. 


\section{CHAPTER V}

\section{CONCLUSION AND RECONMENDATIONS}

\section{Bridgman High School}

On the basis of the findings of this study, Bridgman was not meeting the needs of the potential dropouts. The need in this case was that they have an active involvement in the school. Both Iichter and Urdal found that active involvement was necessary to change the student's attitude toward school and prevent dropping out. Participation was the best way to accomplish this goal.

It is recommended that the administration in the Bridgman High School consult the Activities Preferences list in the Appendix and make a feasability study of implementing the type of activities the potential dropouts and other students expressed the greatest interest in.

\section{St. Joseph High Sichool}

Based on the findings of this study, st. Joseph was not meeting the needs of the potential dropouts to be involved in the school. It is recommended that the St. Joseph Administration seriously re-evaluate the entire program and facilities use schedule. The lack of opportunity to participate, not a factor in dropout participa- 
tion, was a factor for many other students.

It is also recommended that alternative activities be offered that interest more than just the Middle and Upper-middle class students. Appendix B, page 93, contains a list of alternative activities as rated by the total sample and the potential dropouts. The number of interested teachers is also given. Serious consideration should be given to implementing these activity preferences in order to prevent a sharp rise in school dropouts. A feasability study should be made reasonably soon.

\section{General Recommendation}

It is recommended that a replication of this study be done in an effort to refine the process.

Due to the fact that this study was synchronic, a longitudinal study in each school should be made to verify the findings of this study.

It is recommended that this survey/follow-up technique, because of the simplicity of its nature, be used and redesigned as needed in secondary schools on a generalized basis. The identification and prevention of dropouts is not only an educational goal, it is an ethical requirement and a social necessity. 


\section{BIBIIOGRAPHY}

Bellingrath, George C. Qualities Associated with leadership in the Extra-curricular Activities of the High S.chool. New York: 'Teachers College, Columbia University, 1930。

Buros, Oscar K., ed. The 7 th Wental Measurement Yearbook. Highland Park, New Jersey: The Gryphon Press, 1972.

- Tests in Print II. Highland Park, New Jersey: The Gryphon Press, 1974 .

Cohen, Arthur M. "Student Characteristics: Personality and Dropout Propensity." UCIA, ERIC ED 038 130, 1970.

Combs, Arthur. "Humanistic Imperative in an Accountable School." ASCD Audio Tape, 1975.

Cornell, Terry D. Educational Accountability Through Evaluation. Englewood Cliffs, New Jersey: Educational Technology Publications, 1971.

Frederick, Robert $W$. The Third Curriculum. New York: Appleton-Croft, $1 \overline{959}$.

Gordon, Wayne C. The Social System of the High School. Glencoe, Illiñois: The Free Press, 1957.

Greive, Donald E. "A Survey of Student Attitudes." UCLA: ERIC ED 037 212, 1970。

Hill, Russel C. "Dropping Out of High School: The Effects of Family Ability, School Quality and Local Employment Conditions." HEW, Washington, D.C.: ERIC ED 116 102, 1975.

Jacobson, Paul B. The Principalshin: New Perspectives. Englewood Clifis, iNew Jersey: Prentice-Hali, 1973.

Jacobson, Paul B., ed. The American Secondary School. Englewood Ciiffs, New Jersey: prentice-Hall, 1952.

Kassera, Wyane J. "Identification of student Needs and Desires for Educative Experiences Other Than Those Found in the Classroom Environment." Wisconsin State University: ERIC ED 053 432, 1969.

Lichter, Solomon 0. The Dropouts. Glencoe, New York:

The Free Press, 1962 . 
Maxey, James E. "The Accuracy of Self-Report Information Collected on the ACT Test Battery: High School Grades and Items of Non-Academic Achievement." Iowa City: ERIC ED $054738,1917$.

NicCray, James Calvin. Factors Related to Student Partici-

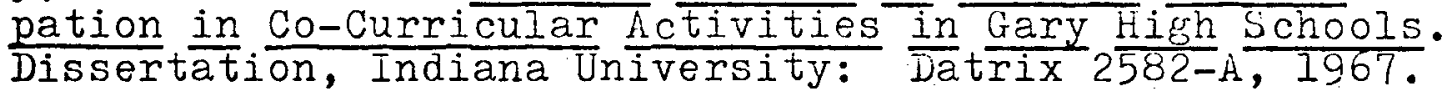

Millholen, I.F., Jr. Improvement of Extra-Class Activities. New York: Parker Publishing Company, 1969.

National Education Association. Profiles of Excellence. Washington, D.C.: NEA, 1966.

National Study of Secondary School Evaluation. Evaluation Criteria. Washington, D.C., 1960.

Robbins, Jerry H. Student Activities in the Innovative School. Minneapolis, Minnesota: B̄urgess Publishing Company, 1969.

Sherrodd, Leo Lawrence. A Study of Co-Curricular Activities for Selected Fontana High Schools. Dissertation, University of Wontana: $\bar{D}$ trix 6959-A, 1973.

"Situdent Speak Up." Fresno City Unified School District: ERIC ED $038745,1968$.

Thomas, Peggy Stone. The Relationship of Physical Fitness to selected Aspects of Intellectual and Academic Performance. Dissertation, Univeristy of ütah: Datrix 3449-A, 1968.

Thompkins, Ellsworth. Extra-Class Activities for all Students. Washington, D.C.: Office of Education, 1950 .

Thompson, Bruce $W$. National Iongitudinal study of the High School Class of 1972. Wasinington, D.C.: Hitw, 1972.

Tolbert, Patsie S. "Survey of Attitudes Towards a Student Activities Program at Johnson County Community College." ERIC ED 051 793, 1971.

Trump, Lloyd J. Secondary School Curriculum Improvement. Boston: Allyn and Bacon, 1973.

Urdal, Lloyd B. "Dropout - An Anslysis of Personal Variables Within the School Situation." Washington Sitate Office of Superintendent of Public Instruction, Olympia: ERIC ED 014 108, 1963. 
APPENDIX A 
St. Joseph High School

First Questionnaire Results

Total Sample $\quad \mathrm{N}=311 \quad 100 \%$

Distribution by:

Age

$\begin{array}{rl}8 \% & 14 \text { or younger } \\ 26 \% & 15 \\ 18 \% & 16 \\ 27 \% & 17 \\ 20 \% & 18 \text { or older }\end{array}$

$\underline{\text { Sex }}$

$44 \% \quad \mathrm{Male}$

56\% Female

Grade Level

$23 \%$

$22 \%$

$21 \%$

$33 \%$

9 th Grade

10 th Grade

lith Grade

12th Grade

Program Track

$76 \%$ College Prep

$13 \%$ Vocational

10\% Business

Jobs

50\% Have a job

$5 \%$ Work less than 5 hours/week

$11 \%$ Work 6 - 10 hours/week

$11 \%$ Work II - 15 hours/week

$10 \%$ Work 16 - 20 hours/week

$9 \%$ Work 21 - 25 hours/week

$9 \%$ Work 26 - 30 hours/week

$2 \%$ Work 31 or more hours/week

Transportation

$41 \%$

$28 \%$

$17 \%$
Rode the bus to school

Drove to school

Own a car 
Academic Grades

$\begin{aligned} 14 \% & \text { Mostly A's } \\ 25 \% & \text { Half A's and half B's } \\ 25 \% & \text { Mostly B's } \\ 24 \% & \text { Half B's and half C's } \\ 9 \% & \text { Mostly C's } \\ 3 \% & \text { Half C's and half D's } \\ 1 \% & \text { Mostly D's }\end{aligned}$

School Spirit

$75 \% \quad$ Positive

First Grade Attended in the School

$2 \%$ Did not initiate high school in St. Joseph

Ethnic Background

$\begin{aligned} 62 \% & \text { Northern European } \\ 8 \% & \text { Southern European } \\ 20 \% & \text { Other } \\ 5 \% & \text { American Indian } \\ 1 \% & \text { Black } \\ 1 \% & \text { Chicano }\end{aligned}$

Financial Support

$77 \%$ Dependent on their families

$4 \% \quad$ Supported one other person

$5 \% \quad$ Supported two or more persons

Socio-Economic Ievel

$\begin{array}{ll}26 \% & \text { Iower Class } \\ 38 \% & \text { Middle Class } \\ 29 \% & \text { Upper-midle Class } \\ 7 \% & \text { Unclassified }\end{array}$

Educational Level of the Father

$3 \%$

$5 \%$

Did not go to high school

$27 \%$

Did not finish high school

$33 \%$

$12 \%$

$8 \%$

$4 \%$

$8 \%$

Graduated high school

Attended college

Graduated college

Post college degree

Doctorate degree

Did not know 


\begin{tabular}{cc} 
Absence & \\
\cline { 1 - 2 } $29 \%$ & $0-2$ days \\
$28 \%$ & $3-5$ days \\
$22 \%$ & $6-9$ days \\
$9 \%$ & $10-12$ days \\
$6 \%$ & $13-15$ days \\
$3 \%$ & $16-20$ days \\
$2 \%$ & $21-24$ days \\
$1 \%$ & $25=30$ days \\
$1 \%$ & Over 30 days
\end{tabular}

\begin{aligned} Reason for & Absence \\ \hline $21 \% &$ Nedical appointment \\ $44 \% &$ Illness \\ $5 \% &$ Travel \\ $1 \% &$ Drug Problems \\ $12 \% &$ Personal Problems \\ $1 \% &$ To avoid tests and reports \\ $5 \% &$ To go somewhere with their friends \\ $12 \% &$ Didn't feel like coming to school \\ $7 \% &$ Other \end{aligned}

Source of Friends

$\begin{aligned} 84 \% & \text { School } \\ 2 \% & \text { Family } \\ 4 \% & \text { Church } \\ 1 \% & \text { Work } \\ 5 \% & \text { Neighborhood } \\ 4 \% & \text { Other }\end{aligned}$

Personal Satisfaction

$\begin{aligned} 3 \% & \text { Class work } \\ 25 \% & \text { School activities } \\ 18 \% & \text { Out of school activities } \\ 6 \% & \text { Work } \\ 11 \% & \text { Hobbies } \\ 34 \% & \text { Unplanned activities } \\ 4 \% & \text { Other }\end{aligned}$

Student Senate

$\begin{array}{ll}7 \% & \text { Members } \\ 47 \% & \text { Felt the senate was doing a good job } \\ 53 \% & \text { Felt the senate was not doing a good job } \\ 16 \% & \text { Felt the Senate was a strong voice for the } \\ 33 \% & \text { students senate was controlled by a few } \\ 27 \% & \text { Felt the Senate had no influence } \\ 23 \% & \text { Felt the Senate was controlled by the } \\ & \text { faculty and administration }\end{array}$




\section{Officers in School Activities $20 \% \quad$ Affirmative response}

Activities Involvement: Percentage represented positive responses to the activities listed below.

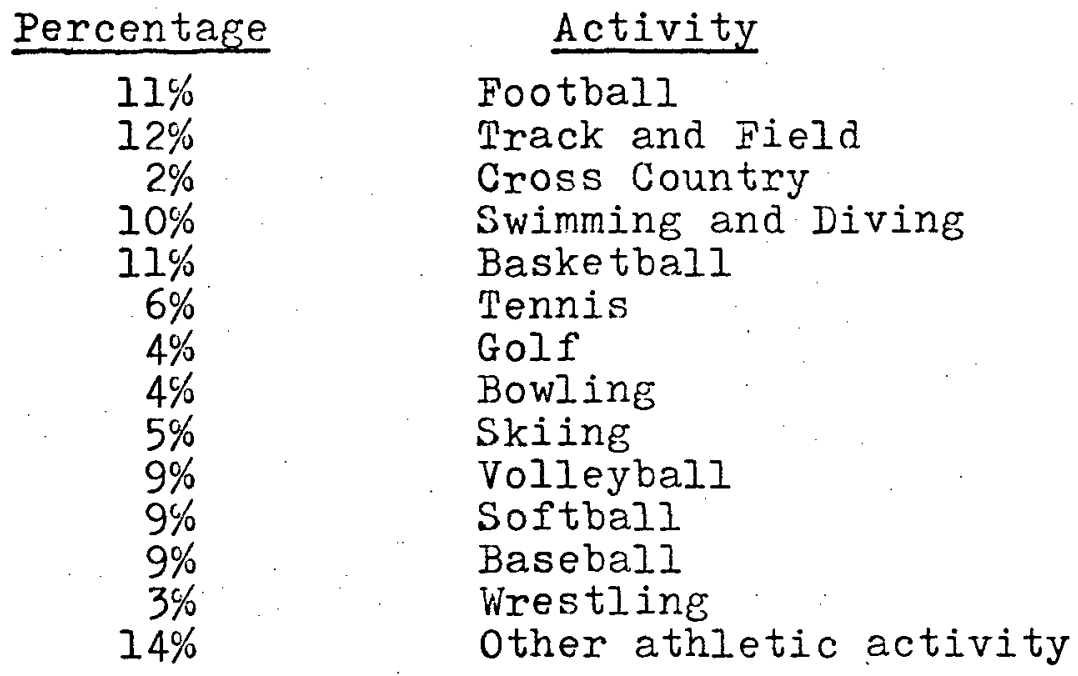

Band

$25 \%$ Were members

$21 \%$ Would like to continue in band

$12 \%$ Would like to join

$41 \%$ Would not like to join

$23 \%$ Would like to learn an instrument

Choral

25\% Were members

$27 \%$ Would like to continue in choral

$21 \%$ Would like to join

$55 \%$ Would not join

Percentage

$7 \%$

$5 \%$

$4 \%$

$6 \%$

$3 \%$

$12 \%$

$14 \%$

$3 \%$

$3 \%$

\author{
Activity \\ Yearbook \\ News paper \\ Freshman Class Organization \\ Sophomore Class Organization \\ Junior Class Organization \\ Senior Class Organization \\ Drama \\ Science $\mathrm{Club}$ \\ Cheerleaders
}


Percentage

$8 \%$

$2 \%$
$3 \%$
$4 \%$

$11 \%$

$10 \%$

$1 \%$

$4 \%$

$2 \%$

$20 \%$

$4 \%$

\author{
Activity \\ Art CIub \\ English Club \\ German Club \\ Math Club \\ Thesbians \\ Honor society \\ French Club \\ Honeybears \\ Spanish Club \\ Troupers \\ Letter club \\ Sophlighters
}

Opinions

$69 \%$ Liked the activities in the school

$30 \%$

Did not have time to be in activities

$3 \%$

Claimed the school would not allow them to be in activities

11\% Did not have the necessary transportation to be in activities

$84 \%$ Had parental support for being in activities

$56 \%$ Belonged to a team or club not connected with the school

$64 \%$ Had most of their activities out of school

$64 \%$ Felt coaches and advisors played favorites

$86 \%$ Iiked to attend sport events

$60 \%$ Liked to attend concerts

$74 \%$

$44 \%$

Iiked to attend plays

Iiked to attend club events

$26 \%$

$64 \%$

Attended school events regularly

Attended school events sometimes

$4 \%$

Attended school events only when they had to

$6 \%$

Never attended school events

$12 \%$

$16 \%$

Were in over 6 activities per year

$34 \%$

Were in 4 - 6 activities per year

$16 \%$

Were in 2 - 3 activities per year

Were in one activity per year

$23 \%$

were in no activities 
Activity Preference: Percentage indicates positive responses.

\section{Percentage}

26

45

34

35

37

23

44

25

39

37

15

18

13

7

22

27

47

49

18

32

43

11

6

22

20

21

25

11

34

8

75

14

4

31

32

30

14

31

16

19

12

17

12

8

13

3
Activity

Football

Basketball

Baseball

Track and Field

Swimming and Diving

Archery

Tennis

Gymnastics

Ping Pong

Pool

Handball

Shooting, Skeet, Riflery

Ice Hockey

Field Hockey

Soccor

Dancing

Volleyball

Skiing

Ice and Figure Skating

Badminton

Bowling

Weightifting

Wrestling

Racquetball

Judo

Karate

Hunting

Gunsmithing

Fishing

Blacksmithing

Canoeing

Trapping

Rock Hounding

Forestry

Ecology

Conservation

Government studies

Youth Problems

Student/Faculty Relations

Law and Society

Inter - school Relations

Foreign Language

CB Radio

Commercial and Ham Radio

Chess

Bridge 
Percentage

25

11

30

25

28

16

15

18

31.

38

11

21

22

11

19

30

29

24

22

14

16

22

14

38

22

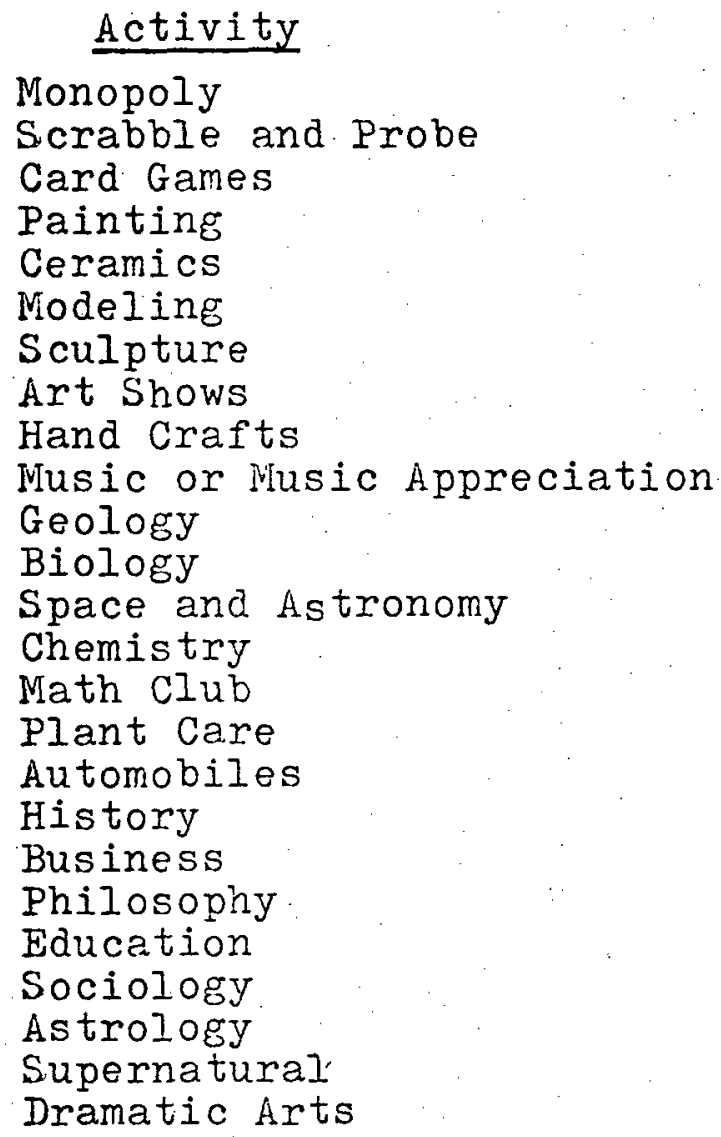


Participants Students who participate in either athletic or non-athletic activities. $84 \%$

Distribution by:

Age

$\begin{array}{rl}8 \% & 14 \text { or younger } \\ 27 \% & 15 \\ 18 \% & 16 \\ 27 \% & 17 \\ 19 \% & 18 \text { or older }\end{array}$

$\underline{\operatorname{Sex}}$

$43 \%$

Male

$57 \%$

Female

Grade Ievel

$25 \%$

$22 \%$

$21 \%$

$31 \%$

9 th Grade

loth Grade

IIth Grade

12th Grade

Program Track

$81 \%$

$10 \%$

College Prep

$8 \%$

Vocational

Business

Jobs

$49 \%$ Have a job

$6 \%$ Work less than 5 hours/week

$11 \%$ Work 6 - 10 hours/week

10\% Work 11 - 15 hours/week

$8 \%$ Work $16-20$ hours/week

$2 \%$ Work 21 - 25 hours/week

$1 \%$ Work 26 - 30 hours/week

Transportation

$41 \%$

$26 \%$

Rode the bus to school

$14 \%$

Drove to school

Own cars 


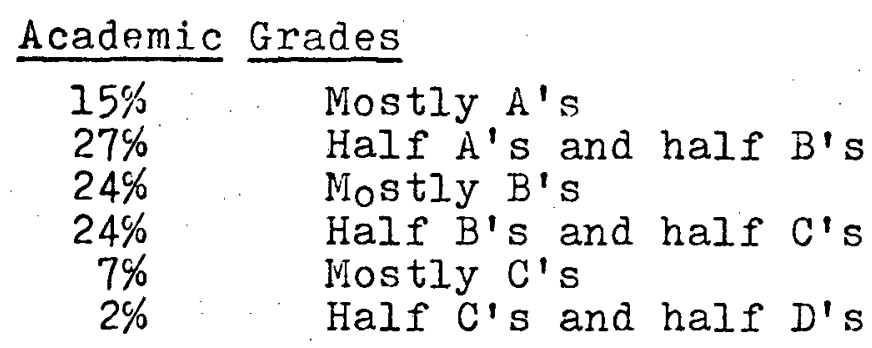

\section{School Spirit}

$$
\text { 82\% Positive }
$$

\begin{tabular}{cc} 
Participation in & School Activities \\
\hline $14 \%$ & Were in 6 activities or more \\
$17 \%$ & Were in $4-6$ activities \\
$40 \%$ & Were in $2-3$ activities \\
$17 \%$ & Were in one activity \\
$12 \%$ & None
\end{tabular}

Ethnic Background

$\begin{aligned} 5 \% & \text { American Indian } \\ 1 \% & \text { Black } \\ 1 \% & \text { Chicano } \\ 67 \% & \text { Northern European } \\ 7 \% & \text { Southern European } \\ 18 \% & \text { Other }\end{aligned}$

Financial Support

78\% Financially dependent on their families

$4 \%$ Supported one other person

$5 \%$ Supported two or more persons

Socio-Ficonomic Ievel

$\begin{array}{cl}22 \% & \text { Lower Class } \\ 39 \% & \text { Middle Class } \\ 32 \% & \text { Upper-midde Class } \\ 7 \% & \text { Unclassified }\end{array}$

Sources of Personal Satisfaction

$\begin{aligned} 3 \% & \text { Class work } \\ 29 \% & \text { School activities } \\ 18 \% & \text { Out of school activities } \\ 6 \% & \text { Work } \\ 10 \% & \text { Hobbies } \\ 28 \% & \text { Unplanned activities }\end{aligned}$


Non-Participants $\quad 15.4 \%$

Students who did not participate in any school activity. Distribution by:

Age

$\begin{array}{rl}4 \% & 14 \text { or younger } \\ 21 \% & 15 \\ 19 \% & 16 \\ 29 \% & 17 \\ 27 \% & 18 \text { or older }\end{array}$

$\underline{\operatorname{sex}}$

$50 \% \quad$ Male

$50 \% \quad$ Female

Grade Level

$\begin{array}{lr}10 \% & 9 \text { th Grade } \\ 21 \% & \text { loth Grade } \\ 15 \% & \text { I1th Grade } \\ 52 \% & \text { 12th Grade }\end{array}$

Jobs

$56 \%$ Have a job

$58 \%$ Claimed work conflicted with their opportunity to participate

$4 \%$ Worked $6-10$ hours/week

$6 \%$ Worked 11 - 15 hours/week

$12 \%$

$15 \%$

$10 \%$

Worked 16 - 20. hours/week

Worked 21 - 25 hours/week

Worked 26 - 30 hours/week

$6 \%$

Worked 31 or more hours/week

Transportation

$40 \%$

$19 \%$

Rode the bus to school

Claimed busing interfered with their opportunity to participate

School Spirit

$79 \%$

Negative 


\section{Ethric Background}

$\begin{aligned} 6 \% & \text { No response } \\ 8 \% & \text { American Indian } \\ 4 \% & \text { Oriental } \\ 38 \% & \text { Northern European } \\ 33 \% & \text { Southern European } \\ 31 \% & \text { Other }\end{aligned}$

Financial Support

$\begin{array}{ll}66 \% & \text { Financially dependent on their families } \\ 8 \% & \text { Supported one other person } \\ 4 \% & \text { Supported two or more people }\end{array}$

Socio-Economic Level

$\begin{array}{cl}49 \% & \text { Lower Class } \\ 35 \% & \text { Midde Class } \\ 10 \% & \text { Upper-midde Class } \\ 6 \% & \text { Unclassified }\end{array}$

Personal Satisfaction

$\begin{aligned} 0 \% & \text { Class work } \\ 2 \% & \text { School Activities } \\ 15 \% & \text { Out of school activi } \\ 4 \% & \text { Work } \\ 19 \% & \text { Hobbies } \\ 54 \% & \text { Unplanned activities } \\ 6 \% & \text { Other }\end{aligned}$

Intramural Interest

$52 \%$ Positive response

Program Track

$\begin{array}{ll}48 \% & \text { College prep } \\ 27 \% & \text { Vocational } \\ 23 \% & \text { Business }\end{array}$

Academic Grades

$\begin{array}{ll}6 \% & \text { Mostly A's } \\ 15 \% & \text { Half A's and half B's } \\ 31 \% & \text { Mostly B's } \\ 20 \% & \text { Half B's and half C's } \\ 17 \% & \text { Mostly C's } \\ 6 \% & \text { Half C's and half D's } \\ 4 \% & \text { Mostly D's }\end{array}$


Students in Athletics Only $\quad 12.5 \%$

Distribution by:

\begin{tabular}{cl} 
Age & \\
$13 \%$ & 14 or younger \\
$38 \%$ & 15 \\
$23 \%$ & 16 \\
$18 \%$ & 17 \\
$7 \%$ & 18 or older \\
Sex & \\
\hline $74 \%$ & Nale \\
$26 \%$ & Female \\
Grade Level & \\
\hline $46 \%$ & 9th Grade \\
$21 \%$ & 10th Grade \\
$13 \%$ & 11th Grade \\
$20 \%$ & 12th Grade
\end{tabular}

Program Track

$79 \%$

$15 \%$

College Prep

$5 \%$

Vocational

Business

Jobs

$\begin{aligned} 44 \% & \text { Have a job } \\ 5 \% & \text { Worked less than } 5 \text { hours/week } \\ 15 \% & \text { Worked } 6-10 \text { hours/week } \\ 18 \% & \text { Worked } 11-15 \text { hours/week } \\ 3 \% & \text { Worked } 16-20 \text { hours/week } \\ 3 \% & \text { Worked } 21-25 \text { hours/week }\end{aligned}$

Transportation

$\begin{aligned} 28 \% & \text { Rode the school bus } \\ 5 \% & \text { Claimed busing interfered with opportunity } \\ 18 \% & \text { to participate } \\ 13 \% & \text { Drove to school } \\ & \text { Own a car }\end{aligned}$


Academic Grades

$\begin{aligned} 5 \% & \text { Mostly A's } \\ 13 \% & \text { Half A's and half B's } \\ 41 \% & \text { Mostly B's } \\ 32 \% & \text { Half B's and half C's } \\ 8 \% & \text { Mostly C's } \\ 3 \% & \text { Below C's }\end{aligned}$

$\frac{\text { School Spirit }}{69 \%}$

69\% Positive

Ethnic Background

$3 \% \quad$ No response

5\% American Indian

64\% Northern European

13\% Southern European

$15 \%$ other

Socio-Economic Level

$18 \%$ Lower Class

$44 \%$ Viiddle Class

23\% Upper-middle Class

15\% Unclassified

Financial Support

$74 \%$

$10 \%$

Financially dependent on their families

$10 \%$

Supported one other person

Supported two or more persons

Personal Satisfaction

$\begin{aligned} 5 \% & \text { Class work } \\ 23 \% & \text { School activities } \\ 18 \% & \text { Out of school activities } \\ 5 \% & \text { Work } \\ 8 \% & \text { Hobbies } \\ 8 \% & \text { Unplanned activities }\end{aligned}$

Participation

$2 \%$ Were in over 6 activities per year

$5 \%$ Were in $4-6$ activities per year

$33 \%$ Were in $2-3$ activities per year

$33 \%$ Were in one activity per year

25\% None 
Students in Non-Athletic Activities Only $\quad 30.2 \%$

Distribution by:

Age

$\begin{array}{ll}11 \% & 14 \text { or younger } \\ 28 \% & 15 \\ 10 \% & 16 \\ 30 \% & 17 \\ 22 \% & 18 \text { or older }\end{array}$

$\underline{\mathrm{Sex}}$

$70 \% \quad$ Female

$30 \%$ Male

Grade Level

$20 \%$

$24 \%$

9 th Grade

loth Grade

$16 \%$

lith Grade

$37 \%$

12th Grade

Program Track

$70 \%$

$9 \%$

$11 \%$

College Prep

Vocational

Business

Jobs

$47 \%$ Have a job

$30 \%$

Claimed work conflicted with opportunity to participate in activities

$4 \% \quad$ Worked less than 5 hours/week

$9 \%$ Worked $6-10$ hours/week

$10 \%$

$12 \%$

$10 \%$

$4 \%$

Worked 11 - 15 hours/week

Worked 16 - 20 hours/week

Worked 21 - 25 hours/week

Worked 26 - 30 hours/week

Transportation

$43 \%$

$15 \%$

$21 \%$

$13 \%$
Rode the school bus

Claimed busing interfered with opportunity to participate in activities

Drove to school

Own a car 
Academic Grades

$\begin{array}{ll}16 \% & \text { Mostly A's } \\ 32 \% & \text { Half A's and half B's } \\ 28 \% & \text { Mostly B's } \\ 15 \% & \text { Half B's and half C's } \\ 7 \% & \text { Mostly C's } \\ 2 \% & \text { Half C's and half D's }\end{array}$

School Spirit
$83 \%$
Positive

Financial Support
82\% Financially dependent on their families $4 \%$ Supported two or more persons

Socio-Economic Level

$\begin{aligned} 20 \% & \text { Lower Class } \\ 36 \% & \text { Midde Class } \\ 28 \% & \text { Upper-midile Class } \\ 6 \% & \text { Unclassified }\end{aligned}$


Students Who Participate in Athletic and Non-Athletic

Activities $\quad 41.8 \%$

Distribution by:

Age

$\begin{array}{rl}5 \% & 14 \text { or younger } \\ 22 \% & 15 \\ 23 \% & 16 \\ 28 \% & 17 \\ 22 \% & 18 \text { or older }\end{array}$

$\underline{\text { Sex }}$

$51 \%$

Male

$49 \%$

Female

Grade Level

$23 \%$

$21 \%$

9th Grade

$23 \%$

loth Grade

$33 \%$

IIth Grade

12th Grade

Program Prack

$82 \%$

$10 \%$

$7 \%$

College Prep

Vocational

Business

Jobs

$53 \%$

$24 \%$

$8 \%$ Worked less than 5 hours per week

$12 \%$

$12 \%$

$11 \%$

$8 \%$

$2 \%$

$2 \%$

Have a job

Claimed work conflicted with opportunity to participate in activities

Worked 6 - 10 hours per week

Worked 11 - 15 hours per week

Worked 16 - 20 hours per week

Worked 21 - 25 hours per week

Worked 26 - 30 hours per week

Worked 31 or more hours per week

\section{Transportation}

$45 \%$

$8 \%$

$31 \%$

$15 \%$
Rode the school bus

Claimed busing interfered with opportunity to participate in activities

Drove to school

Owned a car 
Academic Grades

$\begin{array}{ll}18 \% & \text { Nostly A's } \\ 28 \% & \text { Half A's and half B's } \\ 17 \% & \text { Mostly B's } \\ 29 \% & \text { Half B's and half C's } \\ 8 \% & \text { Iostly C's } \\ 2 \% & \text { Half C's and half D's }\end{array}$

Ethnic Background

$\begin{aligned} 2 \% & \text { No response } \\ 6 \% & \text { American Indian } \\ 1 \% & \text { Black } \\ 1 \% & \text { Chicano } \\ 2 \% & \text { Oriental } \\ 66 \% & \text { Northern European } \\ 5 \% & \text { Southern European } \\ 17 \% & \text { Other }\end{aligned}$

Financial support

$77 \%$ Financially dependent on their families

$5 \%$ Supported one other person

$4 \%$ Supported two or more persons

Socio-Economic Ievel

$\begin{array}{ll}18 \% & \text { Lower Class } \\ 39 \% & \text { Iiddie Class } \\ 38 \% & \text { Upper-middle class }\end{array}$
Personal Satisfaction
$4 \%$ Class work
$42 \% \quad$ School activities
13\% Out of school activities
$4 \%$ Work
10\% Hobbies
$20 \%$ Unplanned activities
$5 \% \quad$ other

Participation

$\begin{aligned} 16 \% & \text { Were in over } 6 \text { activities per year } \\ 28 \% & \text { Were in } 4-6 \text { activities per year } \\ 45 \% & \text { Were in } 2 \text { activities per year } \\ 5 \% & \text { Were in one activity per year }\end{aligned}$


Students Identified as Potential Dropouts $\quad 3.2 \%$

Distribution by:

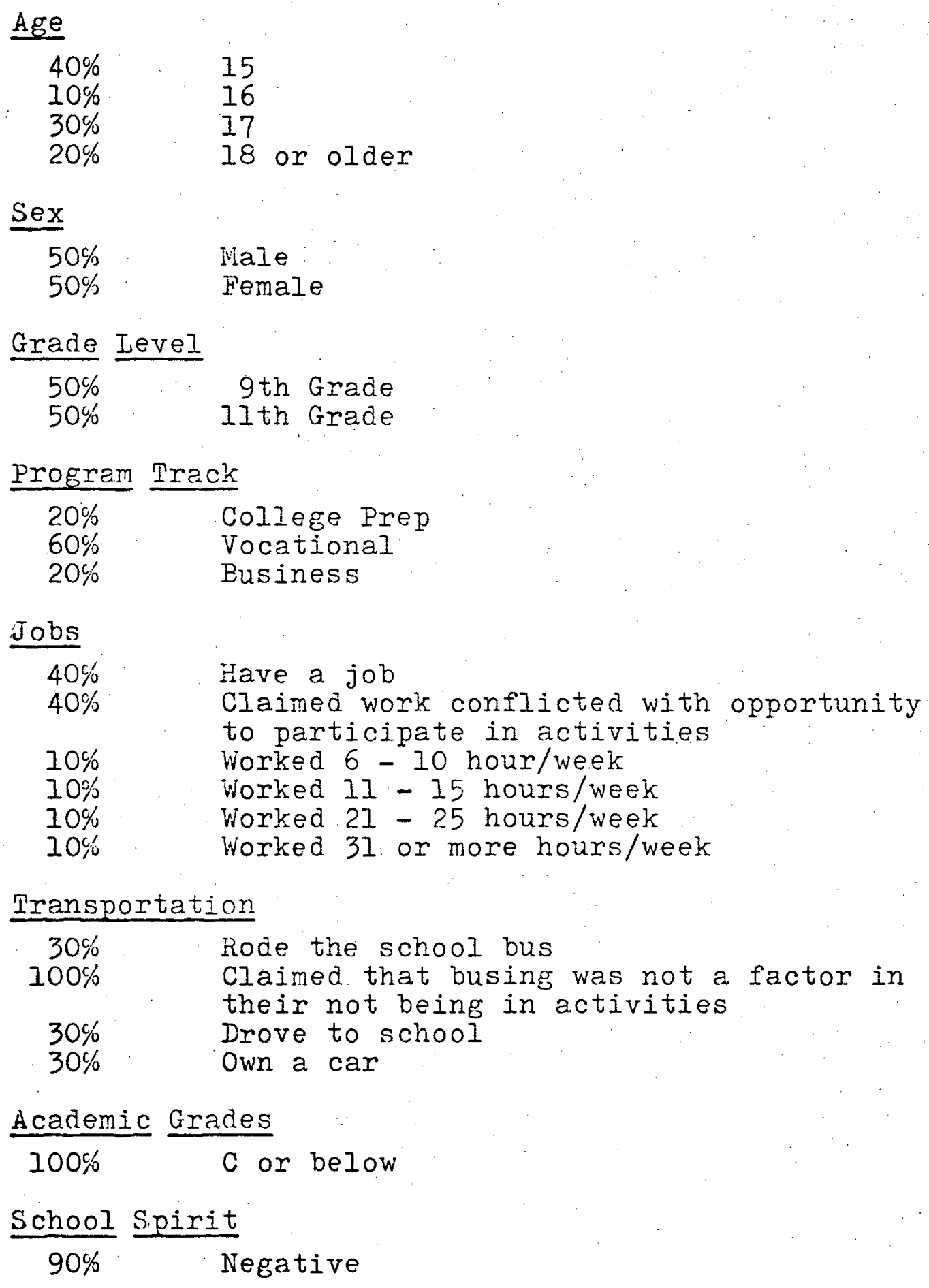


$\begin{array}{cc}\text { First } & \text { Grade Attended in the School } \\ 50 \% & \frac{\text { Sth Grade }}{\text { 10th Grade }} \\ 40 \% & \text { lith Grade }\end{array}$

Ethnic Background

$\begin{array}{ll}20 \% & \text { American Indian } \\ 20 \% & \text { Northern European } \\ 10 \% & \text { Southern Furopean } \\ 50 \% & \text { Did not know }\end{array}$

Pinancial Support

$\begin{array}{ll}50 \% & \text { Financially dependent on their families } \\ 10 \% & \text { Supported one other person } \\ 20 \% & \text { Supported two or more persons }\end{array}$

Socio-Economic Ievel

$80 \% \quad$ Lower Class

$20 \% \quad$ Unclassified

Educational Ievel of the Father

$30 \% \quad$ Did not graduate high school

70\% Graduated high school

\begin{tabular}{cc} 
Absence & \\
\hline $20 \%$ & $3-5$ days \\
$40 \%$ & $6-9$ days \\
$20 \%$ & $10=12$ days \\
$10 \%$ & $13=15$ days \\
$10 \%$ & $21-24$ days
\end{tabular}

Reason for Absence

$10 \%$ Me ical appointment

$10 \% \quad$ Illness

$30 \%$ To go somewhere with friends

$50 \%$ Did not feel like coming to school

Source of Friends

$40 \%$ School

$50 \% \quad$ Neighborhood

10\% Other

Personal Satisfaction

$20 \%$ Out of school activities

60\% Unplanned activities

$20 \%$ Other 
Student Senate

$\begin{array}{ll}80 \% & \text { Felt the senate was not doing a good job } \\ 10 \% & \text { Felt the senate was a strong voice for the } \\ & \text { students } \\ 30 \% & \text { Felt the senate was controlled by a few } \\ 20 \% & \text { Felt the Senate had no influence } \\ 40 \% & \text { Felt the senate was controlied by the } \\ & \text { faculty and administration }\end{array}$

Other Attitudes

$\begin{aligned} 90 \% & \text { Did not like the activities in school } \\ 0 \% & \text { Felt they were being barred from partici- } \\ \text { pation in school activities } & \\ 50 \% & \text { Felt their parents liked them to be in } \\ 30 \% & \text { Belool activities } \\ 50 \% & \text { with the school } \\ 70 \% & \text { Fould like to see other kinds of activities } \\ & \text { Felt coaches and advisors played favorites }\end{aligned}$

Reason for not Being in Activities

30\% Preferred to do things with friends

$30 \%$ Worked

$20 \%$ Felt they had better things to do

10\% Thought activities were dumb

10\% Other

Intramurals

60\% Expressed an interest in an intramural

40\% Undecided

Alternative Activities Having a Response Greater Than 10\%

\begin{tabular}{cl} 
Percentage & Activity \\
\hline 20 & Football \\
20 & Basketball \\
30 & Baseball \\
30 & Swimming \\
50 & Archery \\
30 & Gymnastics \\
30 & Ping Pong \\
30 & Pool \\
20 & Shooting, Skeet and Riflery \\
20 & Ice Hockey \\
40 & Dancing \\
20 & Volleyball
\end{tabular}




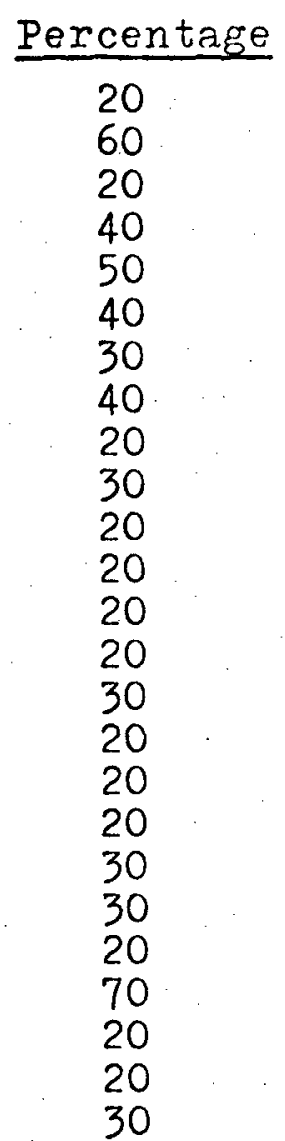

\author{
Activity \\ Badminton \\ Bowling \\ Racque tball \\ Judo \\ Karate \\ Hunting \\ Gunsmithing \\ Fishing \\ Blacksmithing \\ Canoeing \\ Trapping \\ Forestry \\ Conservation \\ Youth Problems \\ $\mathrm{CB}$ Radio \\ Card Grames \\ Painting \\ Ceramics \\ Hand Crafts \\ Space and Astronomy \\ Plant Care \\ Automobiles \\ Sociology \\ Astrology \\ Supernatural
}


Working Non-Participants

$7 \%$

Distribution by:

Age

$24 \%$

$5 \%$

$29 \%$

$43 \%$

15

16

17

18 or older

$\underline{\text { Sex }}$

$57 \%$

$43 \%$

Male

Female

\section{Grade Level}

$\begin{array}{lr}10 \% & 9 \text { th Grade } \\ 14 \% & \text { I0th Grade } \\ 10 \% & 11 \text { th Grade } \\ 67 \% & \text { 12th Grade }\end{array}$

\section{Program Track}

$52 \%$

$29 \%$

$19 \%$

Jobs

$10 \%$

$10 \%$

$14 \%$

$29 \%$

$24 \%$

$14 \%$
College Prep

Vocational

Business

School Spirit

$71 \% \quad$ Negative

Socio-Economic Ievel

$52 \%$

$29 \%$

Lower Class

$14 \%$

worked less than 5 hours/week

Worked 11 - 15 hours/week

Worked 16 - 20 hours/week

Worked 21 - 25 hours/week

Worked 26 - 30 hours/week

Worked 31 or more hours/week

Opportunity

$95 \%$

Midale Class

Upper-middle Class

Claimed work conflicted with participation in school activities 
Bused Students Who Did Not Participate $\quad 10.9 \%$

$100 \%$ answered busing interfered with opportunity to participate in school activities. 


\section{Participation By Socio-Ficonomic Level}

Distribution by:

Lower Class

$26.3 \%$ of Total Sample

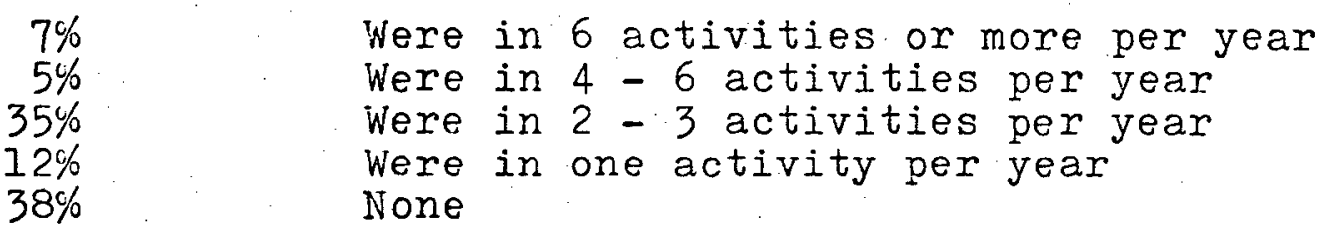

Middle Class

$38.2 \%$ of Total sample

$\begin{aligned} 9 \% & \text { Were in over } 6 \text { activities per year } \\ 22 \% & \text { Were in } 4-6 \text { activities per year } \\ 32 \% & \text { Were in }-3 \text { activities per year } \\ 9 \% & \text { Were in one activity per year } \\ 26 \% & \text { None }\end{aligned}$

Upper-middle Class

$28,2 \%$ of Total Sample

$15 \%$

$21 \%$

$39 \%$

$10 \%$

$13 \%$

were in over 6 activities per year

Were in $4-6$ activities per year

Were in 2 - 3 activities per year

Were in one activity per year

None 
Student Senate Members $\quad 7.07 \%$

Distribution by:

Age

$\begin{array}{rl}5 \% & 14 \text { or younger } \\ 27 \% & 15 \\ 18 \% & 16 \\ 27 \% & 17 \\ 23 \% & 18 \text { or older }\end{array}$

$\underline{\operatorname{sex}}$

$82 \%$

$18 \%$

Female

Male

Grade Ievel

$14 \%$

$32 \%$

$19 \%$

Grade

loth Grade

IIth Grade

$35 \%$

I2th Grade

Program Prack

$95 \%$

$5 \%$

College Prep

Business

Jobs

$55 \%$ Did not work

\section{Transportation}

$\begin{array}{ll}54 \% & \text { Rode the school bus } \\ 22 \% & \text { Drove to school } \\ 5 \% & \text { Own a car }\end{array}$

Academic Grades

$82 \% \quad$ Half $A^{\prime} s$ and half $B^{\prime} s$ or better

School Spirit

90\% Positive

Socio-Economic Ievel

$9 \%$

Lower Class

$45 \%$

Middle Class

$45 \%$

Upper-middle class 
Educational Level of the Father

$\begin{aligned} 4 \% & \text { Did not go to high school } \\ 18 \% & \text { Graduated high school } \\ 4 \% & \text { Attended college } \\ 36 \% & \text { Graduated college } \\ 22 \% & \text { Post college degree } \\ 13 \% & \text { Doctorate degree }\end{aligned}$

$\frac{\text { Source of Friends }}{95 \%} \frac{\text { School }}{9}$

Personal Satisfaction

$36 \%$ Student activities

$31 \%$ Unplanned activities

Student Senate

$\begin{aligned} 59 \% & \text { Felt the Senate was doing a good job } \\ 4 \% & \text { Felt the Senate was a strong voice for the } \\ 50 \% & \text { students } \\ 27 \% & \text { Felt the Senate was controlled by a few } \\ 18 \% & \text { Felt the Senate had no influence } \\ 40 \% & \text { faculty and administration } \\ & \text { Were officers of other clubs and activities }\end{aligned}$

Students Not on the Senate $\quad 93 \%$

Attitude Towards the Senate

$52 \%$ FeIt the Senate was doing a good job

17\% Felt the senate was a strong voice for the

$31 \%$ Felt the senate was controlled by a few

$26 \%$ Felt the senate had no influence

23\% Felt the Senate was controlled by the faculty and administration 
Students Who Are officers in school Activities

Distribution by:

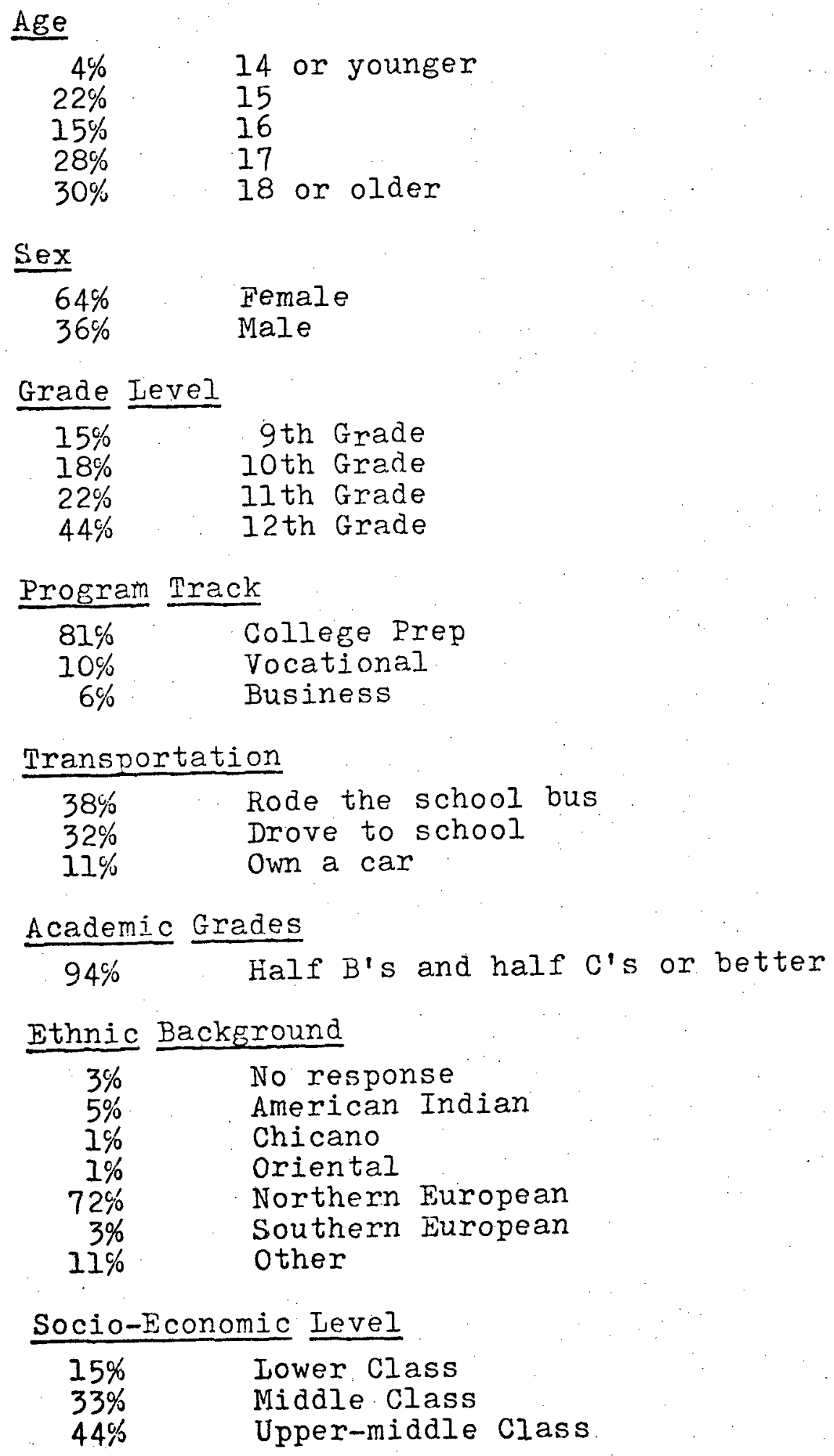

\section{Program Track}

$\begin{aligned} 81 \% & \text { College Prep } \\ 10 \% & \text { Vocational } \\ 6 \% & \text { Business }\end{aligned}$

\section{Transportation}

$\begin{array}{ll}38 \% & \text { Rode the school bus } \\ 32 \% & \text { Drove to school } \\ 11 \% & \text { Own a car }\end{array}$

Academic Grades

$94 \%$ half $B^{\prime} s$ and half $C^{\prime} s$ or better

Ethnic Background

$\begin{aligned} 3 \% & \text { No response } \\ 5 \% & \text { American Indian } \\ 1 \% & \text { Chicano } \\ 1 \% & \text { Oriental } \\ 72 \% & \text { Northern European } \\ 3 \% & \text { Southern European } \\ 11 \% & \text { Other }\end{aligned}$

Socio-Economic Level 
APPENDIX B 
St. Joseph High School

Second Questionnaire Results

Total Sample $\quad \mathrm{N}=302 \quad 100 \%$

Distribution by:

Age

$\begin{array}{rl}7 \% & 14 \text { or younger } \\ 24 \% & 15 \\ 20 \% & 16 \\ 26 \% & 17 \\ 23 \% & 18 \text { or older }\end{array}$

$\underline{\text { Sex }}$

$55 \%$

$45 \%$

Female

rale

Grade Jevel

$24 \%$

$21 \%$

$22 \%$

$32 \%$

9 th Grade

loth Grade

IIth Grade

12th Grade

\section{Program Prack}

$79 \%$

$10 \%$

College Prep

$9 \%$

Vocational

Business

Academic Grade

$\begin{array}{ll}16 \% & \text { Mostly A's } \\ 24 \% & \text { Half A's and half B's } \\ 23 \% & \text { Mostly B's } \\ 26 \% & \text { Half B's and half C's } \\ 7 \% & \text { Mostly' C's } \\ 3 \% & \text { Half C's and half D's } \\ 1 \% & \text { Mostly D's }\end{array}$

Socio-Economic Ievel

$\begin{array}{cl}27 \% & \text { Iower Class } \\ 52 \% & \text { Middle Class } \\ 19 \% & \text { Upper-Middle Class } \\ 2 \% & \text { Unclassified }\end{array}$


School spirit

76\% Positive

Educational Level of the Father

$\begin{aligned} 4 \% & \text { Did not go to high school } \\ 3 \% & \text { Did not finish high school } \\ 25 \% & \text { Graduated high school } \\ 16 \% & \text { Attended college or trade school } \\ 28 \% & \text { Graduated college } \\ 10 \% & \text { Post college degree } \\ 6 \% & \text { Doctorate degree } \\ 9 \% & \text { Did not know }\end{aligned}$


Students in the Potential Dropout Category $\quad 4.3 \%$

Distribution by:

Age

$\begin{array}{rl}8 \% & 14 \text { or younger } \\ 31 \% & 15 \\ 8 \% & 16 \\ 23 \% & 17 \\ 30 \% & 18 \text { or older }\end{array}$

$\underline{\text { Sex }}$

$69 \%$

$31 \%$

Male

Female

$\frac{\text { Grade }}{46 \%}$ LeveI

$54 \%$

9th Grade

IIth Grade

Program Track

$15 \%$

$69 \%$

College Prep

$15 \%$

Vocational

No response

Academic Grade

100\% C or below

Socio-Economic Level

$85 \%$ Iower Class

$15 \%$ Middle Class

Educational of the Father

$15 \%$

$15 \%$

Did not go to high school

$69 \%$

Did not finish high school

Graduated high school

School Spirit

100\% Negative 
Activities Preferences Comparative analysis results of Second Student questionnaire and Teacher's Questionnaire. Student responses are in percentages; teachers' responses are in actual number.

\author{
Activity \\ Animal Care \\ Archery \\ Art $\mathrm{Club}$ \\ Auto Club \\ Badminton \\ Band \\ Baseball Intramurals \\ Baseball Team. \\ Basketball Intramurals \\ Basketball Team \\ Bike Club \\ Biology Club \\ Boating and Sailing \\ Bowling \\ Boxing \\ Business Club \\ Canoeing \\ Cards and Games \\ Cheerleañers \\ Choral \\ Cinema Club \\ Class Organizations \\ Cross Country \\ Dance Class \\ Debate Team \\ Drama Club \\ English Club \\ Football-Girls \\ Football Intramurals \\ Football Team \\ Foreign Ianguage Club \\ Forestry and Conservation \\ Golf \\ Gymnastics \\ Handball \\ Hand Crafts \\ $\mathrm{History} \mathrm{Club}$
}

\begin{tabular}{|c|c|c|}
\hline$\frac{\text { Sample }}{\%}$ & $\frac{\text { Dropout }}{\%}$ & $\frac{\text { Teacher }}{\text { Response }}$ \\
\hline 75 & 0 & 3 \\
\hline 14 & 39 & 3 \\
\hline 12 & 0 & 4 \\
\hline 6 & 23 & 3 \\
\hline 20 & 15 & 3 \\
\hline 15 & 0 & 2 \\
\hline 11 & 0 & 6 \\
\hline 14 & 8 & 6 \\
\hline 18 & 0 & 9 \\
\hline 21 & 8 & 11 \\
\hline 24 & 0 & 9 \\
\hline 3 & 0 & 1 \\
\hline 31 & 0 & 9 \\
\hline 18 & 15 & 8 \\
\hline 7 & 8 & 1 \\
\hline 5 & 0 & 3 \\
\hline 44 & 15 & 10 \\
\hline 5 & 8 & 4 \\
\hline 6 & 0 & 5 \\
\hline 16 & 0 & 3 \\
\hline 12 & 0 & 5 \\
\hline 5 & 0 & 5 \\
\hline 3 & 0 & 4 \\
\hline 15 & 8 & 2 \\
\hline 7 & 0 & 4 \\
\hline 11. & 0 & 8 \\
\hline$+\frac{1}{2}$ & 0 & 0 \\
\hline 10 & 0 & 3 \\
\hline 8 & 0 & 6 \\
\hline 14 & 8 & 11 \\
\hline 8 & 0 & 3 \\
\hline 14 & 16 & 0 \\
\hline 9 & 8 & 10 \\
\hline 18 & 8 & 5 \\
\hline 7 & 8 & 4 \\
\hline 6 & 16 & 5 \\
\hline 4 & 0 & 2 \\
\hline
\end{tabular}




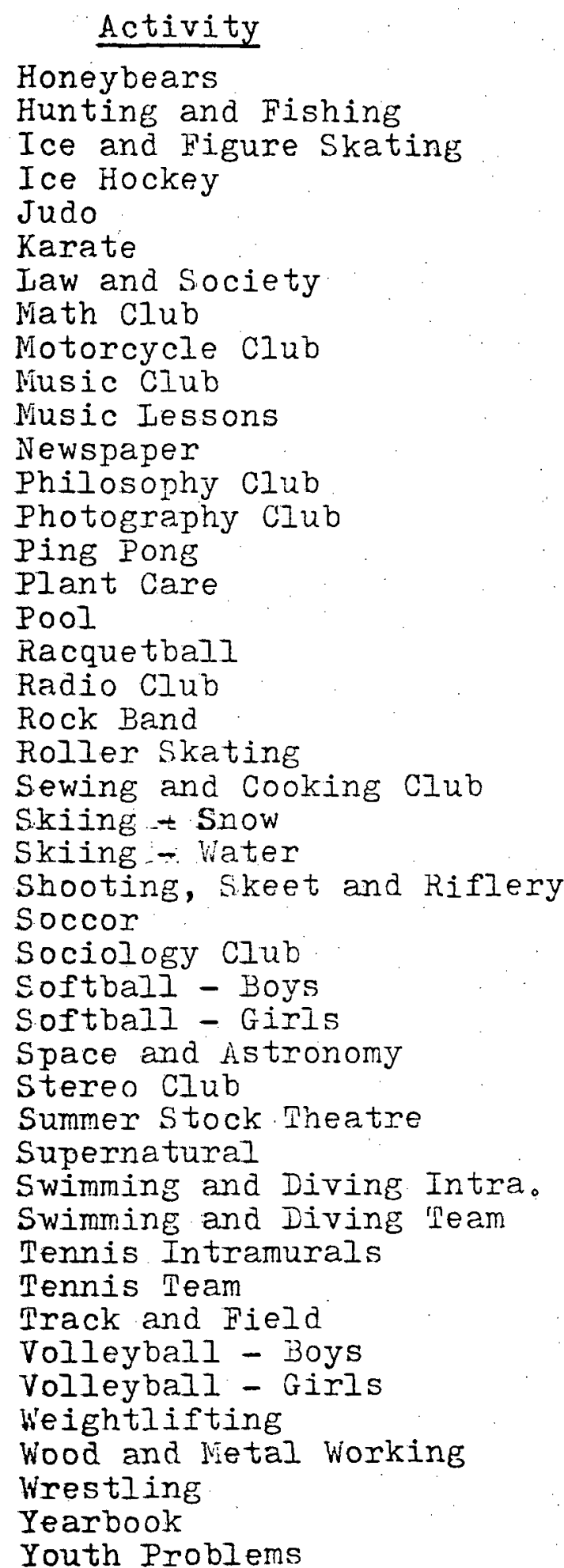

\begin{tabular}{|c|c|c|}
\hline$\frac{\overline{\text { Sample }}}{\frac{\%}{\alpha}}$ & $\frac{\text { Dropout }}{\%}$ & $\begin{array}{l}\text { Teacher } \\
\text { Response }\end{array}$ \\
\hline 2 & 0 & 3 \\
\hline 16 & 46 & 8 \\
\hline 11 & 0 & 4 \\
\hline 4 & 8 & $i$ \\
\hline 10 & 31 & 0 \\
\hline 12 & 31 & 0 \\
\hline 7 & 8 & 5 \\
\hline 5 & 0 & 7 \\
\hline 15 & 46 & 0 \\
\hline 13 & 8 & 5 \\
\hline 15 & 8 & 2 \\
\hline 10 & 0 & 5 \\
\hline 7 & 0 & 1 \\
\hline 25 & 23 & 5 \\
\hline 24 & 31 & 3 \\
\hline 11 & 8 & 2 \\
\hline 20 & 54 & 2 \\
\hline 7 & 0 & 5 \\
\hline 7 & 16 & 0 \\
\hline 26 & 46 & 1 \\
\hline 12 & 16 & 4 \\
\hline 7 & 0 & 3 \\
\hline 38 & 16 & 13 \\
\hline 34 & 23 & 5 \\
\hline 13 & 46 & 6 \\
\hline 9 & 8 & 1 \\
\hline 5 & 0 & 0 \\
\hline 8 & 8 & 1 \\
\hline 19 & 15 & 5 \\
\hline 5 & 8 & 4 \\
\hline 20 & 46 & 1 \\
\hline 5 & 0 & 4 \\
\hline 16 & 23 & 0 \\
\hline 15 & 0 & 6 \\
\hline 16 & 0 & 5 \\
\hline 21 & 8 & 6 \\
\hline 20 & 0 & 7 \\
\hline 22 & 8 & 8 \\
\hline 6 & 0 & 3 \\
\hline 26 & 16 & 7 \\
\hline 8 & 23 & $\begin{array}{l}2 \\
4\end{array}$ \\
\hline 5 & 8 & 4 \\
\hline 4 & 0 & 2 \\
\hline 17 & 0 & 5 \\
\hline 12 & 8 & 10 \\
\hline
\end{tabular}


APPENDIX C 


\section{Bridgman High School}

First Questionnaire Results

Total Sample $\quad N=188 \quad 100 \%$

Distribution by:

Age

$$
\begin{array}{rl}
10.5 \% & 14 \text { or younger } \\
30.4 \% & 15 \\
29.1 \% & 16 \\
21.7 \% & 17 \\
8.1 \% & 18 \text { or older }
\end{array}
$$

Sex

$$
51.5 \% \text { Males }
$$

$$
\text { 48. } 4 \% \text { Females }
$$

Grade

$$
\begin{array}{lr}
32.92 \% & 9 \text { th Grade } \\
22.4 \% & \text { 10th Grade } \\
25.5 \% & \text { 11th Grade } \\
18.0 \% & \text { 12th Grade }
\end{array}
$$

\section{Program Track}

$\begin{array}{ll}33.54 \% & \text { College Prep } \\ 43.48 \% & \text { Vocational } \\ 14.29 \% & \text { Business }\end{array}$

\section{Jobs}

$$
\begin{aligned}
49.07 \% & \text { Have a job } \\
5.5 \% & \text { Work less than } 5 \text { hours/week } \\
12.4 \% & \text { Work } 6-10 \text { hours/week } \\
6.8 \% & \text { Work } 11-15 \text { hours/week } \\
11.8 \% & \text { Work } 16-20 \text { hours/week } \\
6.2 \% & \text { Work } 21-25 \text { hours/week } \\
3.7 \% & \text { Work } 26-30 \text { hours/week } \\
3.1 \% & \text { Work } 31 \text { or more hours/week }
\end{aligned}
$$

Busing

$$
37.27 \% \text { Are bused }
$$

Drive

$32.30 \%$ Drive to school 
Cars

$$
33.54 \% \text { Own cars }
$$

Academic Grades

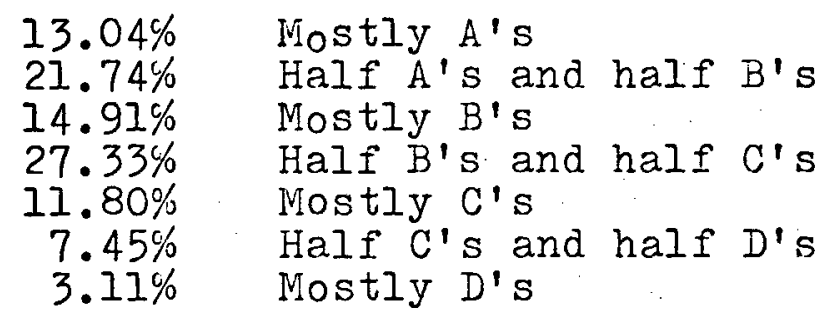

School Spirit

78.26\% Positive

First Grade Attended in the School

$\begin{array}{rr}90 \% & 9 \text { th Grade } \\ 2 \% & \text { loth Grade } \\ 3 \% & \text { l1th Grade } \\ 2 \% & \text { 12th Grade }\end{array}$

Ethnic Background

$\begin{array}{ll}5.59 \% & \text { No response } \\ 8.70 \% & \text { American Indian } \\ 1.24 \% & \text { Black } \\ 1.24 \% & \text { Oriental } \\ 50.31 \% & \text { INorthern European } \\ 6.21 \% & \text { Southern European } \\ 26.71 \% & \text { Other }\end{array}$

Financial support

$70.19 \%$ Depend on their families

$5.59 \%$ Support one other person

$6.21 \%$ Support two other persons

Socin-Economic Ievel

$\begin{aligned} 55 \% & \text { Iower Class } \\ 26 \% & \text { Middle Class } \\ 6 \% & \text { Upper-middle Class } \\ 11 \% & \text { Unclassified }\end{aligned}$

Educational Level of the Father

$8.7 \%$ Did not go to high school

16.7\% Did not graduate nigh school

$27.3 \%$ High school graduates

$14.9 \%$ Attended college

8.1\% Graduated college. 


$\begin{aligned} 2.4 \% & \text { Post college degree } \\ 1.2 \% & \text { Doctorate } \\ 20.5 \% & \text { Do not know }\end{aligned}$

Absence

$\begin{array}{rr}21.7 \% & 0-2 \text { days } \\ 29.1 \% & 3-5 \text { days } \\ 15.5 \% & 6=9 \text { days } \\ 17.3 \% & 10-12 \text { days } \\ 2.4 \% & 13-15 \text { days } \\ 1.8 \% & 16=20 \text { days } \\ 2.4 \% & 21-24 \text { days } \\ 3.1 \% & 25-30 \text { days } \\ 4.3 \% & \text { Over } 30 \text { days }\end{array}$

$\frac{\text { Reason for }}{21.7 \%} \frac{\text { Absence }}{\text { Appointments }}$

$40.4 \%$ IIIness

4. 3\% Travel

1. $2 \%$ Drug problems

$6.2 \%$ Personal problems

$0.0 \%$ Avoidance of tests

$5.6 \%$ To go somewhere with friends

$13.66 \%$ Did not feel like coming to school

$6.2 \%$ Other

Source of Friends

$\begin{aligned} 89.4 \% & \text { School } \\ 1.8 \% & \text { Family } \\ 2.4 \% & \text { Church } \\ 0.0 \% & \text { Work } \\ 3.1 \% & \text { Neighborhood } \\ 2.5 \% & \text { Other }\end{aligned}$

Personal Satisfaction

$1.8 \%$ Classwork

$19.8 \%$ School activities

$12.4 \%$ Out of school activities

$14.3 \%$ Work

$11.2 \%$ Hobbies

$36.0 \%$ Unplanned activities

$3.1 \%$ other

Student senate

$3.7 \%$ Members

72.7\% Felt the Senate was doing a good job

26.1\% Felt the Senate was a strong voice for the students

43.5\% Felt it was controlled by a few 
8.1\% Felt the Senate had no influence

20.5\% Felt the Senate was controlled by the faculty/administration

Officers

87.5\% Were not officers in any clubs or organizations

Activities Involvement: Percentage represented positive responses to the activities listed below.

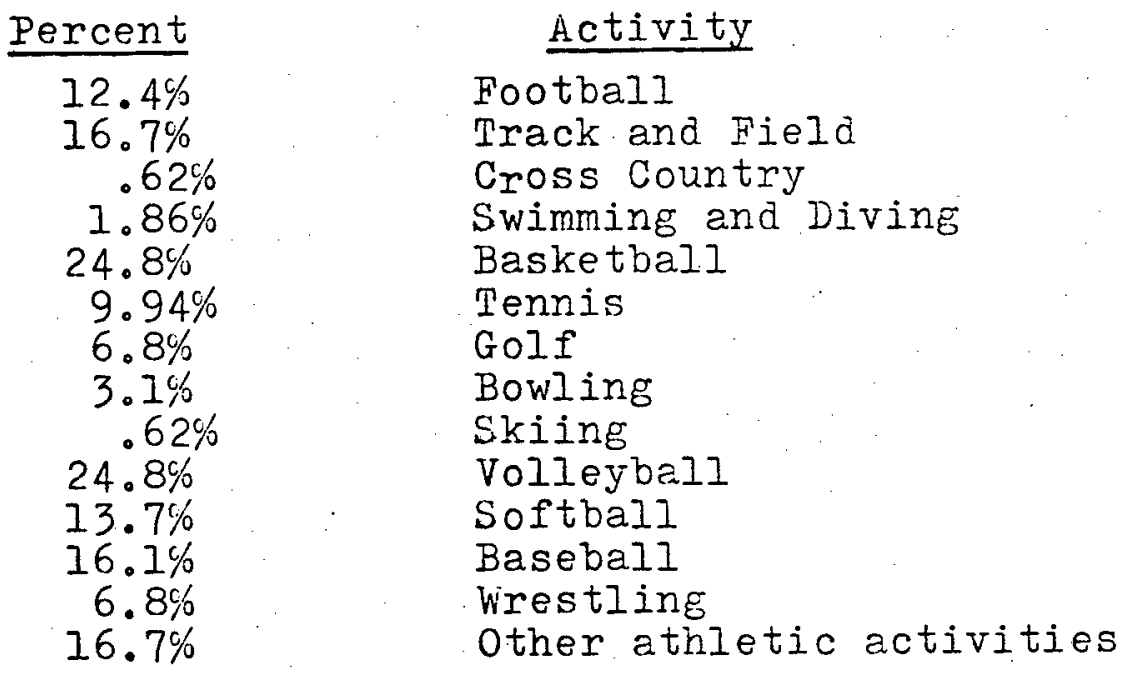

Band

$17.4 \%$

$12.4 \%$

$3.7 \%$

$59.6 \%$

$22.9 \%$

Were members

Would like to continue in band

Would like to be in band

Would not like to be in band

would like to learn an instrument

Choral

$22.4 \%$

$20.5 \%$

$12.4 \%$

$66.5 \%$

Percent

$8.1 \%$

$11.8 \%$

$8.7 \%$

$9.9 \%$

Were Members

Would like to continue in choral

Would like to join

Would not like to join

Activity

Newspaper

Yearbook

Freshman Class Organization

Sophomore Class Organization 
Percent

$13.1 \%$

$11.8 \%$

$14.9 \%$

$3.7 \%$

$1.1 \%$

$23.6 \%$

$6.2 \%$

$6.8 \%$

$4.9 \%$

$5.5 \%$

$4.9 \%$

$10.5 \%$

$7.4 \%$

$.62 \%$

$6.2 \%$

$3.7 \%$
Activity

Junior Class Organization

Senior Class Organization

Drama

FHA

RIVS

Science Club

Cheerleaders

Art $\mathrm{Club}$

English Club

German $\mathrm{Club}$

Nath Club

Honors Society

French Club

Medical Club

GAA

Letter Club

Opinions

$57.1 \%$

$24.2 \%$

$3.7 \%$

$8.1 \%$

$80.7 \%$

$27.3 \%$

$72.0 \%$

$55.9 \%$

$66.5 \%$

$76.0 \%$

$45.0 \%$

$71.0 \%$

$30.0 \%$

$24.0 \%$

$59.0 \%$

$3.0 \%$

$13.0 \%$

$7.4 \%$

$16.7 \%$

$31.0 \%$

$18.0 \%$

$26.0 \%$
Liked the clubs and activities in school worked and did not have time to be in activities

Are not allowed to be in activities by the school

Rode the bus and did not have the transportation to be in activities

Felt their parents wanted them to be in activities

Belonged to teams and clubs not connected with the school

Wanted to see more kinds of activities in the school

Had most of their activities out of school

Felt the coaches and advisors played favorites

Iiked to attend sports events

liked to attend concerts

liked to attend plays

Iiked to attend club activities

Attended school events regularly

Attended school events sometimes

Attended school events only when they had to Never attended school events

Were in over 6 activities per year

Were in $4-6$ activities per year

Were in 2 - 3 activities peryear

Were in one activity per year

Were in no activities 
Activities Preference: Percentage indicates positive responses.

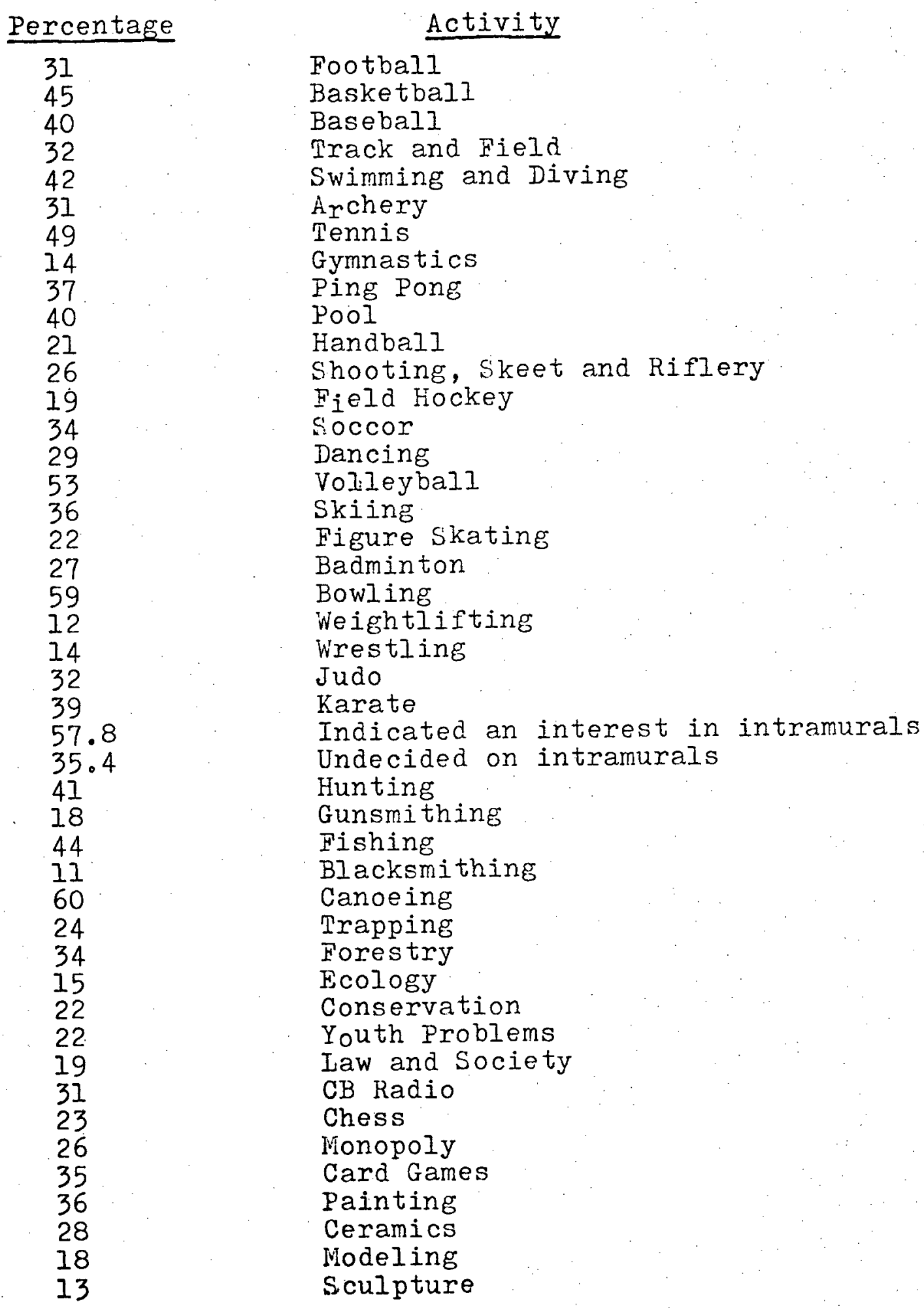

31

45

40

32

42

31

49

14

37

40

21

26

19

34

29

53

36

22

27

59

12

14

32

39

57.8

35.4

$4 I$

18

44

11

60

24

34

15

22

22

19

31

23

26

35

36

28

18

13

\section{Activity}

Football

Basketball

Baseball

Track and Field

Swimming and Diving

Archery

Tennis

Gymnastics

Ping Pong

Pool

Handball

Shooting, skeet and Riflery

Field Hockey

soccor

Dancing

Volleyball

Skiing

Figure Skating

Badminton

Bowling

Weightlifting

Wrestling

Judo

Karate

Indicated an interest in intramurals

Undecided on intramurals

Hunting

Gunsmithing

Fishing

Blacksmithing

Canoeing

Trapping

Forestry

Ecology

Conservation

Youth Problems

Law and Society

CB Radio

Chess

Monopoly

Card Games

Painting

Ceramics

Modeling

sculpture 
Percentage

18
32
21
26
25
37
20
11
9
15
29
15
Activity

Art Shows

Hand Crafts

Music or music appreciation

Biology

Plant Care

Automobiles

Business

Philosophy

Education

Sociology

Supernatural

Dramatic Arts 
Participants Students who participate in either athletic or non-athletic activities. $82.6 \%$

Distribution by:

\section{Age}

$\begin{array}{rl}10.5 \% & 14 \text { or younger } \\ 30.8 \% & 15 \\ 26.3 \% & 16 \\ 22.5 \% & 17 \\ 9.7 \% & 18 \text { or older }\end{array}$

$\underline{\text { Sex }}$

$46.6 \% \quad \mathrm{Niale}$

$53.4 \%$. Female

Grade Leve1

$\begin{array}{lr}31 \% & 9 \text { th Grade } \\ 24 \% & 10 \text { th Grade } \\ 20 \% & \text { l1th Grade } \\ 21 \% & 12 \text { th Grade }\end{array}$

Program Prack

$37 \%$

$39 \%$

$13 \%$

Jobs

$51 \%$
$6 \%$
$11 \%$
$8 \%$
$12 \%$
$6 \%$
$3 \%$
$3 \%$

Busing

$36 \%$

Drive

$35 \%$

Cars

$32 \%$
College Prep

Vocational

Business

Have a job

Work less than 5 hours/week

Work 6- 10 hours/week

Work 11 - 15 hours/week

Work 16 - 20 hours/week

Work 21 - 25 hours/week

Work 26 - 30 hours/week

Work 31 or more hours/week

Are bused

Drive to school

Own cars 
Academic Grades

$\begin{array}{ll}16 \% & \text { Mostly A's } \\ 24 \% & \text { Half A's and half B's } \\ 17 \% & \text { Mostly B's } \\ 27 \% & \text { Malf B's and half C's } \\ 8 \% & \text { Mostly C's } \\ 6 \% & \text { Half C's and half D's } \\ 1 \% & \text { Mostly D's }\end{array}$

School Spirit

$82 \%$ Positive

Participation

$\begin{array}{ll}9 \% & \text { Over } 6 \text { activities per year } \\ 19 \% & 4-6 \text { activities per year } \\ 36 \% & 2-3 \text { activities per year } \\ 19 \% & \text { One activity per year } \\ 15 \% & \text { None }\end{array}$

Ethnic Background

$\begin{aligned} 6 \% & \text { No response } \\ 7 \% & \text { American Indian } \\ 1 \% & \text { Black } \\ 1 \% & \text { Oriental } \\ 54 \% & \text { Northern European } \\ 6 \% & \text { Southern European } \\ 21 \% & \text { Other }\end{aligned}$

Support

$70 \%$

$5 \%$

$6 \%$

Financially dependent on their families

Support one other person

Support two or more persons

Socio-Economic Level

$\begin{aligned} 52 \% & \text { Iower Class } \\ 28 \% & \text { Middle Class } \\ 7 \% & \text { Upper-middle Class } \\ 17 \% & \text { Unclassified }\end{aligned}$

Sources of Personal Satisfaction

$\begin{aligned} 2 \% & \text { Class work } \\ 24 \% & \text { School activities } \\ 12 \% & \text { Out of school activit } \\ 8 \% & \text { Work } \\ 12 \% & \text { Hobbies } \\ 36 \% & \text { Unplanned activities } \\ 3 \% & \text { Other }\end{aligned}$


Non-Participants $\quad 17.4 \%$

Students who do not participate in any school activity. Distribution by:

$\underline{\text { Age }}$

$\begin{array}{rl}11 \% & 14 \text { or younger } \\ 28 \% & 15 \\ 42 \% & 16 \\ 18 \% & 17 \\ 0 \% & 18 \text { or older }\end{array}$

$\underline{\text { Sex }}$

$75 \%$ Nale

25\% Female

Grade Ievel

$\begin{array}{rr}39 \% & 9 \text { th Grade } \\ 10 \% & \text { I0th Grade } \\ 50 \% & \text { I1th Grade } \\ 0 \% & \text { l2th Grade }\end{array}$

Program Track

$\begin{array}{ll}14 \% & \text { College Prep } \\ 64 \% & \text { Vocational } \\ 17 \% & \text { Business }\end{array}$

Jobs

$39 \%$ Have a job

$32 \%$ Claim work conflicts with their opportunity to participate

$3 \%$ Work less than 5 hours/week

$17 \%$ Work 6 - 10 hours/week

$7 \%$ Work 16 - 20 hours/week

$3 \% \quad$ Work $21-.25$ hours/week

$7 \%$ Work 26 - 30 hours/week

\section{Transportation}
$42 \%$
Rode the school bus
$10 \%$
Claimed busing interfered with their oppor- tunity to participate

School spirit

57\% Negative 
Ethnic Background

$\begin{aligned} 14 \% & \text { American Indian } \\ 32 \% & \text { Northern European } \\ 3 \% & \text { Southern European } \\ 50 \% & \text { Other }\end{aligned}$

Financial Support

$75 \%$

$7 \%$

Financially dependent on their families

$3 \%$

Supported one other person

Supported two or more persons

Socio-Economic Level

$67 \%$

$17 \%$

Lower Class

$3 \%$

Middle Class

Upper-middle class

Personal Satisfaction

$\begin{aligned} 0 \% & \text { Class work } \\ 0 \% & \text { School activities } \\ 10 \% & \text { Out of school activities } \\ 42 \% & \text { Work } \\ 7 \% & \text { Hobbies } \\ 35 \% & \text { Unplanned activities } \\ 3 \% & \text { Other }\end{aligned}$

$\frac{\text { Intramural }}{14 \%} \frac{\text { Interests }}{\text { Positive response }}$

Academic Grades

$0 \%$ Irostly A's

$11 \%$ half $A^{\prime} s$ and half $B^{\prime} s$

4\% Nostly B's

$29 \%$ Half $B^{\prime} s$ and half $C^{\prime} s$

29\% Wostly C's

$14 \%$ Half $C^{\prime}$ 's and half $D^{\prime} \mathrm{s}$

$14 \%$ Mostly D's 
Students in Athletic Activities Only $\quad 14.2 \%$

Distribution by:

\begin{tabular}{ll}
\multicolumn{1}{l}{ Age } & \\
$8 \%$ & 14 or younger \\
$26 \%$ & 15 \\
$43 \%$ & 16 \\
$21 \%$ & 17 \\
Sex & \\
\hline $70 \%$ & Male \\
$30 \%$ & Female \\
Grade Level & \\
\hline $30 \%$ & 9 th Grade \\
$34 \%$ & loth Grade \\
$17 \%$ & lith Grade \\
$13 \%$ & l2th Grade \\
Program & Track. \\
\hline $39 \%$ & College Prep \\
$34 \%$ & Vocational \\
$8 \%$ & Business
\end{tabular}

Jobs

$39 \%$ Have a job

$8 \% \quad$ Clained work conflicted with opportunity to participate

$8 \%$ Work less than 5 hours/week

$8 \%$ Work 6 - 10 hours/week

$13 \%$ Work 16 - 20 hours/week

8\% Work $21-25$ hours/week

Transportation

$\begin{array}{ll}26 \% & \text { Rode the school bus } \\ 4 \% & \text { Claimed busing interfered with opportunity } \\ 43 \% & \text { to participate } \\ 30 \% & \text { Drive to school }\end{array}$


Academic Grades

$\begin{array}{ll}13 \% & \text { Mostly A's } \\ 17 \% & \text { Half A's and half B's } \\ 17 \% & \text { Mostly B's } \\ 30 \% & \text { Half B's and half C's } \\ 13 \% & \text { Mostly C's } \\ 4 \% & \text { Half C's and half D's } \\ 4 \% & \text { Mostly D's }\end{array}$

School Spirit

$78 \%$

Positive

Ethnic Background

$17 \%$

$4 \%$

No response

$56 \%$

$4 \%$

American Indian

Northern European

$17 \%$

Southern European

other

Socio-Economic Level

$65 \%$

Iower Class

$13 \%$

Viddle Class

$17 \%$

Upper-middle Class

Financial Supnort

$73 \%$

$4 \%$

Financially dependent on their families

$4 \%$

Support one other person

Support two or more persons

Personal Satisfaction

$\begin{aligned} 4 \% & \text { No response } \\ 0 \% & \text { Class work } \\ 26 \% & \text { School activities } \\ 4 \% & \text { Out of school activities } \\ 13 \% & \text { Work } \\ 13 \% & \text { Hobbies } \\ 34 \% & \text { Unplanned activities } \\ 4 \% & \text { Other }\end{aligned}$

Participation

$\begin{array}{ll}8 \% & \text { Were in } 4-6 \text { activities } \\ 39 \% & \text { Were in } 2-3 \text { activities } \\ 43 \% & \text { Were in one activity }\end{array}$ 


\section{Students in Non-Athletic Activities only $\quad 16.7 \%$}

Distribution by:

Age

$\begin{array}{rl}22 \% & 14 \text { or younger } \\ 25 \% & 15 \\ 29 \% & 16 \\ 14 \% & 17 \\ 7 \% & 18 \text { or older }\end{array}$

$\underline{\operatorname{sex}}$

$67 \%$

Female

$33 \%$

Male

Grade Level

$\begin{array}{rr}48 \% & 9 \text { th Grade } \\ 7 \% & \text { loth Grade } \\ 33 \% & \text { I1th Grade } \\ 11 \% & \text { 12th Grade }\end{array}$

Program Track

$18 \%$

$51 \%$

College Prep

$11 \%$

Vocational

Business

Jobs

$\begin{aligned} 41 \% & \text { Have a job } \\ 33 \% & \text { Claimed work conflicted with opportunity } \\ 7 \% & \text { to participate in activities } \\ 71 \% & \text { Work less than } 5 \text { hours/week } \\ 7 \% & \text { Work } 6-10 \text { hours/week } \\ 3 \% & \text { Work } 11-15 \text { hours/week } \\ 3 \% & \text { Work } 16-20 \text { hours/week } \\ 4 \% & \text { Work } 21-25 \text { hours/week } \\ 7 \% & \text { Work } 31 \text { or more hours/week }\end{aligned}$

Transportation

$37 \%$

Rode the school bus

$29 \%$

Drove to school

$29 \%$

Own a car

$7 \%$

Claimed busing interfered with opportunity to participate in activities 
Academic Grades

$\begin{array}{ll}11 \% & \text { Mostly A's } \\ 18 \% & \text { Half A's and half B's } \\ 22 \% & \text { Mostly B's } \\ 29 \% & \text { Half B's and half C's } \\ 3 \% & \text { Mostly C's } \\ 11 \% & \text { Half C's and half D's }\end{array}$

School Spirit

$77 \% \quad$ Positive

Financial Support

$\begin{array}{ll}48 \% & \text { Financially dependent on families } \\ 3 \% & \text { Support one other person } \\ 49 \% & \text { No response }\end{array}$

Socio-Economic IeveI

$\begin{array}{ll}51 \% & \text { Lower Class } \\ 22 \% & \text { Niddle Class } \\ 25 \% & \text { Unclassified }\end{array}$


Students Who Participate in Athletic and Non-Athletic Activities $\quad 51.5 \%$

Distribution by:

Age

$\begin{array}{rl}7 \% & 14 \text { or younger } \\ 33 \% & 15 \\ 20 \% & 16 \\ 25 \% & 17 \\ 11 \% & 18 \text { or older }\end{array}$

Sex

55\% Female

$45 \%$ Male

Grade LeveI

$\begin{array}{lr}26 \% & 9 \text { th Grade } \\ 27 \% & \text { IDth Grade } \\ 16 \% & \text { I1th Grade } \\ 27 \% & \text { I2th Grade }\end{array}$

Program Prack

$43 \%$

$36 \%$

Coliege Prep

$15 \%$

Vocational

Business

Jobs

$57 \%$

$5 \%$

$12 \%$

$10 \%$

$15 \%$

$7 \%$

$3 \%$

$3 \%$

Have a job

Work 5 hours or less per week

Work 6 - 10 hours/week

Work 11 - 15 . hours/week

Work 16 - 20 hours/week

Work 21 - 25 hours/week

Work 26 - 30 hours/week

Work 31 or more hours/week

Transportation

$38 \%$

$34 \%$

$33 \%$

Rode the school bus

Drove to school

Own a car 
Academic Grades

$\begin{array}{ll}18 \% & \text { Mostly A's } \\ 27 \% & \text { Half A's and half B's } \\ 15 \% & \text { Mostly B's } \\ 25 \% & \text { Half B's and half C's } \\ 8 \% & \text { Mostly C's } \\ 4 \% & \text { Half C's and half D's }\end{array}$

Ethnic Background

$\begin{aligned} 4 \% & \text { No response } \\ 7 \% & \text { American Indian } \\ 2 \% & \text { Black } \\ 1 \% & \text { Oriental } \\ 54 \% & \text { Northern European } \\ 4 \% & \text { Southern European } \\ 25 \% & \text { Other }\end{aligned}$

Financial support

$\begin{array}{cl}75 \% & \text { Financially dependent on their families } \\ 6 \% & \text { Support one other person } \\ 9 \% & \text { Support two or more persons }\end{array}$

Socio-Economic Level

$\begin{aligned} 49 \% & \text { Lower Class } \\ 34 \% & \text { Niddle Class } \\ 7 \% & \text { Upper-midale Class } \\ 8 \% & \text { Unclassifiec }\end{aligned}$

Personal Satisfaction

$\begin{aligned} 2 \% & \text { Class work } \\ 30 \% & \text { School activities } \\ 12 \% & \text { Out of school activities } \\ 7 \% & \text { Work } \\ 9 \% & \text { Hobbies } \\ 33 \% & \text { Unplanned activities } \\ 3 \% & \text { Other }\end{aligned}$

Participation

$\begin{array}{ll}13 \% & \text { Were in over } 6 \text { activities } \\ 25 \% & \text { Were in } 4-6 \text { activities } \\ 40 \% & \text { Were in } 2 \text { activities } \\ 12 \% & \text { Were in one activity }\end{array}$


Students Identified as Potential Dropouts $\quad 4.3 \%$

Distribution by:

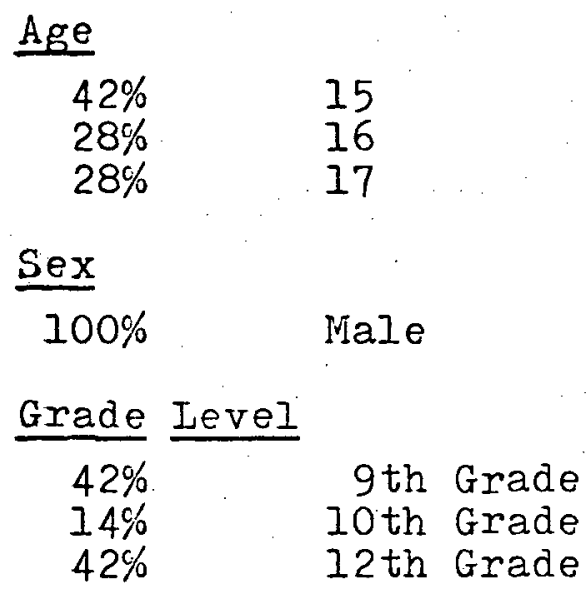

Program Track

$85 \% \quad$ Vocational

$14 \%$ Business

Jobs

28\% Have a job; all work less than 10 hours/week

14\% Claimed work conflicted with opportunity to participate in activities

Transportation

$\begin{aligned} 28 \% & \text { Rode the school bus } \\ 0 \% & \text { Drove to school } \\ 28 \% & \text { Own a car }\end{aligned}$

Academic Grades

100\% C's or below

School Spirit

$\begin{array}{cc}71 \% & \text { Negative } \\ \text { First } & \text { Grade } \\ \begin{array}{l}85 \% \\ 14 \%\end{array} & \frac{\text { Attended }}{9 \text { th Grade }} \\ 11 \text { th Grade }\end{array}$

Ethnic Background

$\begin{array}{ll}14 \% & \text { American Indian } \\ 85 \% & \text { Did not know }\end{array}$ 
Financial Support

$85 \%$ Financially dependent on their families

14\% Supported one other person

Socio-Economic Level

$85 \% \quad$ Lower Class

$14 \%$. Middle Class

Educatjonal Level of the Father

$28 \%$ Did not go to high school

$14 \%$ Did not graduate high school

$57 \%$ Did graduate high school

Absence

$\begin{array}{ll}28 \% & 0-2 \text { days } \\ 28 \% & 2-4 \text { days } \\ 28 \% & 10-12 \text { days } \\ 14 \% & \text { Over } 30 \text { days }\end{array}$

Reason for Absence

$57 \%$ IIIness

$14 \%$ To go somewhere with friends

$14 \%$ Did not feel like coming to school

$14 \% \quad$ other

Source of Friends

100\% School

Personal Satisfaction

$14 \%$ Out of school activities

$57 \%$ Work

$14 \%$ Hobbies

14\% Unplanned activities

Student Senate

$74 \% \quad$ Felt the Senate was doing a good job

42\% Felt the Senate was a strong voice for the students

14\% Felt the Senate was controlled by a few

$14 \%$ Felt the senate had no influence

28\% Felt the Faculty and Administration controlled the Senate 
Other Attitudes

$71 \%$ Did not like the school activities

0\% Felt they were being barred from school activities

42\% Felt their parents liked them to be in

$14 \%$ Belonged to other clubs or organizations not in the school

$28 \%$ Would like to see more kinds of activities in the school

$28 \% \quad$ Felt coaches and advisors played favorites

Reason for not Being in Activities

$14 \%$ No response

14\% Preferred to be with friends

$71 \%$ Felt they had better things to do

Intramurals

$57 \%$ Would join an intramural program

$42 \% \quad$ Undecided

$0 \% \quad$ Negative response

Alternative Activities Having a Rosponse Greater Than $14 \%$

Percentage

57

42

57

28

57

28

57

86

42

25

27

28

28

28

76

57

42

77

28

70

71

71

42

28
Activity

Football

Basketball

Baseball

Swimming

Archery

Tennis

Ping Pong

Pool

Shooting, skeet, and Riflery

Ice Hockey

Field Hockey

Soccor

Volleyball.

Badminton

Bowling

Judo

Karate

Hunting

Gunsmithing

Fishing

Canoeing

Trapping

Forestry

Ecology 
Percentage

42

28

28

57

29

28

28

28
Activity

Conservation

Chess

Monolopy

Card Games

Modeling

Hand Crafts

Geology

Automobiles 


\section{Working Non-Participants $\quad 5.5 \%$}

Distribution by:

Age

$11 \%$

$66 \%$

$22 \%$

15

16

17

$\underline{\operatorname{sex}}$

$88 \%$

$12 \%$

Male

Female

Grade Leve1

$22 \%$

$77 \%$

9th Grade

IIth Grade

Program Track

$22 \%$

$66 \%$

$11 \%$

College Prep

Vocational

Business

Jobs

$11 \%$

$33 \%$

$11 \%$

$11 \%$

$11 \%$

Work less than 5 hours/week

Work 6-10 hours/week

Work 16 - 20 hours/week

Work 21 - 25 hours/week

Work 26 - 30 hours/week

School Spirit

$55 \%$

Negative

Socio-Economic Level

$66 \%$

$11 \%$

$11 \%$

Lower Class

Middle Class

$11 \%$

Upper-midale Class

Unclassified

Opportunity

$100 \%$

Claimed work conflicted with participation in school activities 
Bused Students Who Did Not Participate $6.2 \%$ 100\% answered busing interfered with opportunity to participate in school activities. 


\section{Participation By Socio-Fconomic Levels}

Distribution by:

Lower Class

$55 \%$ of Total Sample

$\begin{aligned} 6 \% & \text { Were in over } 6 \text { activities per year } \\ 12 \% & \text { Were in } 4-6 \text { activities per year } \\ 31 \% & \text { Were in } 2-3 \text { activities per year } \\ 22 \% & \text { Were in one activity per year } \\ 27 \% & \text { None }\end{aligned}$

Middle Class

$26 \%$ of Total Sample

$5 \%$ Were in over 6 activities per year

$35 \%$

Were in $4-6$ activities per year

$37 \%$

Were in 2 - 3 activities per year

$5 \%$

Were in one activity per year

$16 \%$ None

Upper-middle Class

$6 \%$ of Total Sample

$\begin{array}{ll}23 \% & \text { Were in over } 6 \text { activities per year } \\ 7 \% & \text { Were in } 4 \text { activities per year } \\ 30 \% & \text { Were in }-3 \text { activities per year } \\ 15 \% & \text { Were in one activity per year } \\ 23 \% & \text { None }\end{array}$




\section{Student Senate Members $\quad 3.7 \%$}

Distribution by:

\section{Age}

$50 \%$

$17 \%$

14 or younger

$33 \%$

18 or older

$\underline{\operatorname{sex}}$

$66 \%$

$34 \%$

Female

Irale

$\frac{\text { Grade }}{50 \%}$ Level

$50 \%$

9th Grade

llth Grade

Program Track

$\begin{array}{ll}50 \% & \text { College Prep } \\ 16 \% & \text { Vocational. } \\ 34 \% & \text { Business }\end{array}$

Jobs

$66 \%$ Have a job

Transportation

$33 \%$ Rode the bus to school

$50 \%$ Drove to school

$50 \% \quad$ Own a car

Academic Grades

$16 \%$

$33 \%$

Mostly A's

$33 \%$

Half $A^{\prime} S$ and half $B^{\prime} \cdot S$

$16 \%$

Half $B^{\prime} s$ and half $C^{\prime} S$

Mostly C's

$\frac{\text { School }}{100 \%} \frac{\text { Spirit }}{\text { Positive }}$

Socio-Economic Level

$33 \%$

$33 \%$

$16 \%$

$16 \%$

Iower Class

Middle Class

Upper-middle Class

Unclassified 
Educational Level of the Father

$16 \%$

$16 \%$

$16 \%$

$33 \%$

$16 \%$

Did not finish high school

Graduated high school

Attended college

Graduated college

Did not know

Source of Friends

$83 \%$

$16 \%$

School

Family

Personal Satisfaction

$33 \%$

$33 \%$

Class work

$16 \%$

School activities

$16 \%$

out of school activities

Unplanned activities

Student Senate

83\% Felt the senate was doing a good job

66\% Felt the Senate was a strong voice for

16\%: Felt it had no influence

$50 \%$ Were officers of other clubs and activities

Students Not on the Senate $\quad 96.3 \%$

Attitude Towards the Senate

$72 \%$ Felt the Senate was doing a good job

24\% Felt the Senate was a strong voice for

$45 \% \quad$ Felt the senate was controlled by a few

$7 \%$ Felt the Senate had no influence

$21 \%$ Felt the senate was controlled by the

faculty and administration 
Students Who Are Officers in School Activities . 12.4\% Distribution by:

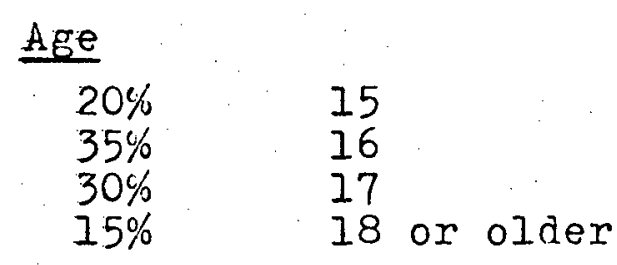

$\underline{\text { Sex }}$

$\begin{array}{ll}55 \% & \text { Female } \\ 45 \% & \text { Nale }\end{array}$

Grade Ievel

$\begin{array}{rr}5 \% & 9 \text { th Grade } \\ 40 \% & \text { I0th Grade } \\ 25 \% & \text { IIth Grade } \\ 30 \% & \text { I2th Grade }\end{array}$

Program Track

$45 \%$

$35 \%$

College Prep

$20 \%$

Vocational

Business

Transportation

$35 \%$ Rode the school bus

60\% Drove to school

Academic Grades

$80 \% \quad B$ or above

Ethnic Background

$\begin{array}{ll}5 \% & \text { American Indian } \\ 75 \% & \text { European }\end{array}$

Socio-Economic Level

$\begin{array}{ll}45 \% & \text { Lower Class } \\ 30 \% & \text { Midde Class } \\ 10 \% & \text { Upper-middle Class } \\ 15 \% & \text { Unclassified }\end{array}$


APPENDIX D 


\section{Bridgman High School}

Second Questionnaire Results

Total Sample $\quad \mathrm{N}=182 \quad 100 \%$

Distribution by:

Age

$8 \% \quad 14$ or younger

$25 \%$

$31 \%$

$23 \%$

$11 \%$

15

16

17

18 or older

$\underline{\operatorname{sex}}$

$52 \%$. Wale

$48 \%$ Female

Grade level

$30 \% \quad 9$ th Grade

23\% 10th Grade

$29 \%$ IIth Grade

16\% 12th Grade

Program Track

37\% College Prep

$43 \%$ Vocational

$14 \%$ Business

Academic Grades

$\begin{aligned} 13 \% & \text { Mostly A's } \\ 21 \% & \text { Half A's and half B's } \\ 17 \% & \text { Mostly B's } \\ 25 \% & \text { Half B's and half C's } \\ 11 \% & \text { Mostly C's } \\ 9 \% & \text { Half C's and half D's } \\ 1 \% & \text { Mostly D's }\end{aligned}$

Socio-Economic Ievel

$\begin{array}{ll}58 \% & \text { Lower Class } \\ 25 \% & \text { Middle Class } \\ 11 \% & \text { Upper-middle Class }\end{array}$


Educational Level of the Father

$\begin{aligned} 7 \% & \text { Did not go to high school } \\ 17 \% & \text { Did not finish high school } \\ 29 \% & \text { Graduated high school } \\ 14 \% & \text { Attended college or trade school } \\ 9 \% & \text { Graduated college } \\ 3 \% & \text { Post college degree } \\ 1 \% & \text { Doctorate degree } \\ 15 \% & \text { Did not know }\end{aligned}$

School Spirit

75\% Positive 
Students in the Potential Dropout Category

Distribution by:

$\begin{array}{cc}\text { Age } & \\ 15 \% & 15 \\ 53 \% & 16 \\ 30 \% & 15\end{array}$

$\underline{\text { Sex }}$

100\% Male

Grade Level

$\begin{array}{rr}23 \% & 9 \text { th Grade } \\ 7 \% & \text { l0th Grade } \\ 61 \% & \text { l1th Grade } \\ 7 \% & \text { 12th Grade }\end{array}$

Program Track

$15 \%$

$53 \%$

College Prep

$23 \%$

Vocational

Business

Academic Grade

$100 \% \quad C$ or below

Socio-Economic Level

$76 \% \quad$ Lower Class

15\% Middle Class

$7 \%$ : Upper-middle Class

Educational Level of the Father

15\% Did not go to high school

$38 \%$ Did not finish high school

46\% Graduated high school

School Spirit

100\% Negative 
Activities Preferences Comparative analysis results of Second Student Questionnaire and Teacher's Questionnaire. Student responses are in percentages; teachers' responses are in actual number.

\author{
Activity \\ Archery \\ Art $\mathrm{Club}$ \\ Astrology \\ Auto Club \\ Badminton \\ Baking and Cooking Club \\ Band \\ Baseball Intramurals \\ Baseball Team \\ Basketball Intramurals \\ Basketball Team \\ Biking $\mathrm{Club}$ \\ Biology Club \\ Bowling \\ Business Club \\ Canoeing \\ Cheerleaders \\ Chemistry Club \\ Choral \\ Cinema Club \\ Class Organizations \\ Cross Country \\ Dance Class \\ Debate Team \\ Education $\mathrm{Club}$ \\ FHA \\ Field Hockey \\ Foreign Language $\mathrm{Club}$ \\ Forestry and Conservation \\ Football - Girls \\ Football Intramurals \\ Football Team \\ GAA \\ Games \\ Geology Club \\ Golf \\ Gunsmithing
}

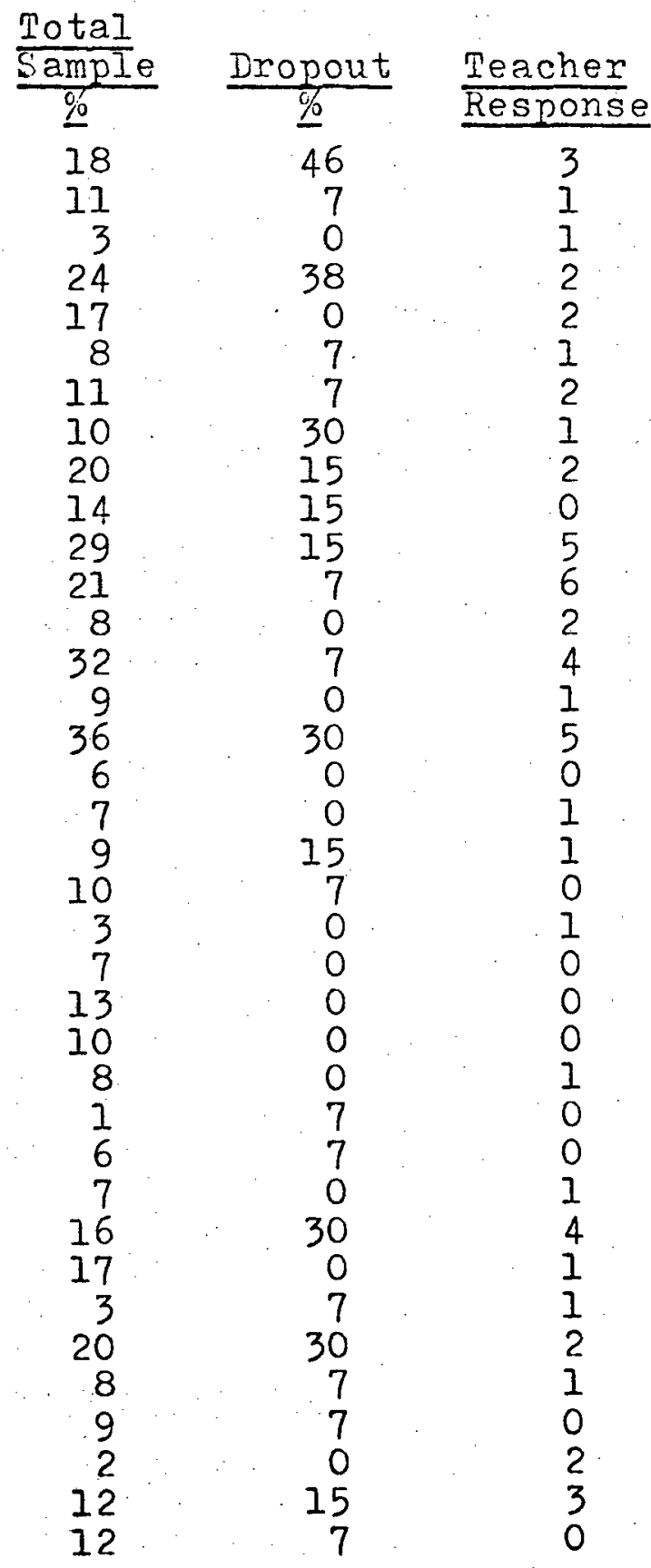




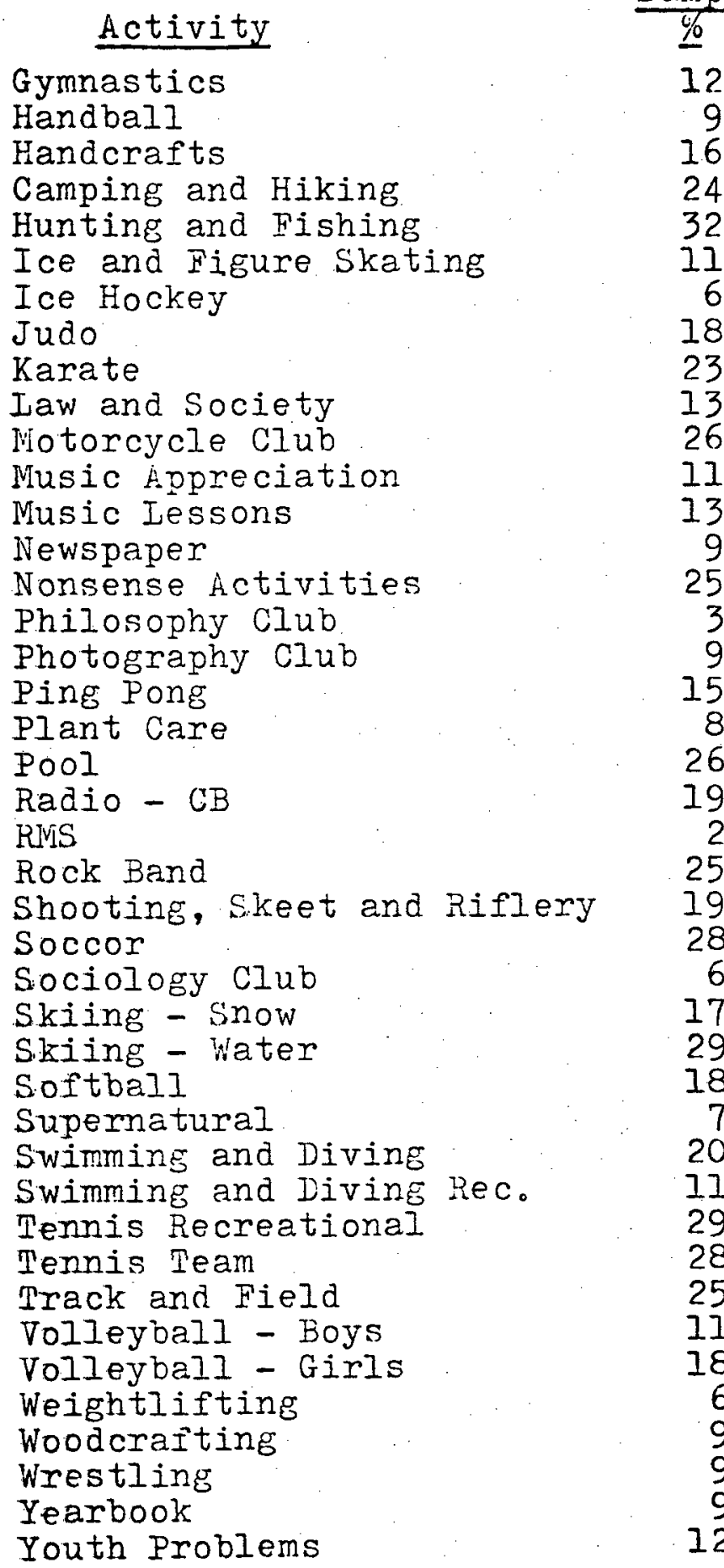


APPENDIX E 


\section{STUDENT INTEREST QUESTIONNAIRE}

Directions

Do Not put your name on this test.

Answer each of the following questions as best as you can.

Put your choice in the box on the left of each question.

\section{PART I}

$\square$ 1. I attend:

1. SJHS

2. BHS

$\square$ 2. My age is:

1. 14 or younger

2. 15

3. 16

4. 17

5. 18 or older

$\square$ 3. Sex:

1. Male

2. Femalo

$\square$ 4. My present grade level is:

1. 9 th

2. 20 th

3. 1Ith

4. 12 th

$\square$ 5. My school program is:

1. College Prep

2. Vocational

3. Business

$\square$ 6. Do you have a job?

2. Yes

$\square$ 7. How many hours per week do you work?

1. I do not work.

2. 5 or less

3. 6 - 10 hours

4. $11-15$ hours

5. 16 - 20 hours

6. $21-25$ hours

7. $20-30$ hours

8. 31 or more hours 
8. Do you ride the bus to school?

1. Yes

2. No

$\square$ 9. Do you drive yoursele to school?

1. No $^{\text {2. }}$

10. Do you own a car?

1. Yes

2. No

11. How are your school grades?

1. Mostly A's

2. Half $A^{\prime} s$ and half $B^{\prime} s$

3. Mostly B's

4. Half $B^{\prime} s$ and half C's

5. Mostly C's

6. Half C's and hale D's

7. Mostly D's

8. Below D's

L' 12. Do you feel you have school spirit?

1. Yes

13. What was the first grade level you attended in this school?

1. 9th Grade

2. IOth Grade

3. 11th Grade

4. 12th Grade

$\square$ 14. What are your ethnic roots?

1. American Indian

2. Black - Afro-American

3. Chicano

4. Oriental

5. Northern European

6. Southern European

7. Uther

$\square$ 15. Do you depend on your family for financial (money) support? 1. Yes

2. No

16. How many people depend on you for support?

1. None

2. One

3. Two or more 
17. What is your father's job (occupation)?

18. What is the highest level of your father's education?

1. Did not go to high $8 \mathrm{chool}$

2. Did not finish high school

3. High school graduate

4. Attended colloge

5. College graduate

6. Post college degree

7. Docturate degree

8. I do not know

$\square$ 19. How many days have you been absent this year?

I. $\quad 0-2$
2. $3=5$
3. $\quad 6=9$
4. $10=12$
5. $13=15$
6. $16=20$
7. $21=24$
8. $25=30$
9. Over 30

$\square$ 20. The main reason for being absent had been:

1. Dentist and Doctor appointments

2. Illness

3. Family travel

4. Drug problems

5. Personal problems

6. To avoid tests and reports

7. To go somewhere with my friends

8. I didn't feel like coming to school

9. Other

$\square$ 21. Most of my friends come from:

1. School

2. Pamily

3. Church

4. Work

5. Neighborhood

6. Other

$\square$ 22. Which gives you the most personal satisfaction?

1. Class work

2. Sports or school activities

3. Out of school activities

4. Outside work

5. Hobbies

6. Doing things with friends (unplanned activities)

7. Other 


\section{PART II}

$\square$ 23. Are you on the Student Senate?

$$
\text { 2. Yes }
$$

$\square$ 24. Do you feel the student Senate is doing a good job?

$$
\text { 1. Yes }
$$

I 25. Do you feel the Student Senate:

1. Is a strong voice for the student

2. Is controlied by a few

3. Has no influence in the school

4. Is controlied by the teachers and administration

$\square$ 26. Are you an officer in any school club or organization?

2. Yes

$\Gamma$ 27. Do you play on a school football team?

1. Yes

2. No

L 28. Do you play on a school track team?

1. YeB

$\Gamma$ 29. Do you play on a cross country team?

2. Yos

30. As you a member of a swimming and diving team?

1. Yes

2. No

31. Do you play on a basketball team?

1. Yes

32. Do you play on a tennis team?

2. Yes

33. Do you play on a golf team?

1. Yes

34. Do you play on a bowling team?

1. Yes

2. No 
I 35. Are you a member of a ski team?

1. Yes

2. No

I 36. Do you play on a volleyball team?

1. Yo8

2. No

T/37. Do you play on a softball team?

1. Yes

2. No

T. 38. Do you play on a baseball team?

2. Yes

$\square$ 39. Are you a member of a wresting team?

1. Yes

2. No

$\square$ 40. Are you a member of any other sport/athletic activity?

1. Yes

2. No

E/41. Are you a member of the band or orchestra?

1. Yes

2. No

$\prod$ 42. Would you like to:

1. Continue in band

2. $B e$ in a band

3. Not be in a band

4. Learn to play an instrument

$\square$ 43. Are you in any choral groups?

1. Yes

2. No

$\longrightarrow$ 44. Would you like to:

1. Continue in choral groups

2. Join a choral group

3. Not be in a choral group

7 45. Are you involved in the newspaper?

1. Yes

2. No

I 46. Are you involved in the yearbook?

1. Yes

2. No 
L 47. Are you involved in the Preshman class organization?

2. Yes

$\square$ 48. Are you involved in the Sophomore class organization?

1. Yes

2. No

$\prod$ 49. Are you involved in the Junior class organization?

1. Yes

2. No

$\square$ 50. Are you involved in the Senior Class organization?

1. Yes

2. No

L 51. Are you involved in Drama?

1. Yes

2. No

I 52. Are you involved in $\mathrm{HHA}$ ?

1. Yes

2. No

T 53. Are you involved in RMS?

1. Yes

2. No

$\square$ 54. Are you involved in Science Club?

2. Yes

I 55. Are you a Cheerleader?

1. Yes

2. No

I 56. Are you involved with the Art Club?

1. Yes

2. No

L 57. Are you involved with the English Club?

1. Yes

2. No

$\square$ 58. Are you involved with the German ulub?

1. Yos

2. No

$\square$ 59. Are you involved with the Math Club?

1. Yes

2. No 
/ $/ 60$. Are you a member of the Thesbians?

1. Yes

$I$ 61. Are you a member of the Honor Soclety?

1. Yes

T. 62. Are you a member of the French Club?

1. Yes

2. No

$\square$ 63. Are you a member of the Honeybears?

1. Yes

2. No

I 64. are you involved with the Medical Club?

1. Yes

2. No

/. / 65. Are you involved with the Spanish lilub?

1. Yes

2. No

1. 66. Are you a member of the Troopers?

1. Yes

2. No

1. 67. Are you a memiber of the GAA?

1. Yes

2. No

/ 68. Are you in the Letter viub?

1. Yes

2. No

1. 69. Are you a member of the Sophlighters?

1. Yes

/ / 70. I like the clubs and activities in the school.

1. Irue

2. Palse

/ / 71. I work and do not nave time to be in scnool activities.

1. True

2. Falso 
7 72. The school w1ll not allow mo to be in any school activitios. 2. True

$\square$ 73. I take the bus and do not have transportation to be in school activities.

2. True

L74. My parents like me to be in school activities.

1. True

2. False

I 75. I belong to a team or club not connected with the school. 1. True

776. I would like to see more kinds of activities in this school. 3. True

2. False

177. Most of my activities are out of school.

1. True

2. False

T/78. I feel the activities' advisors and coaches play favorites. 1. True

2. False

II 79. I I1ke to attend school sporting events.

1. True

2. False

180. I like to attend school concerts.

1. True

2. Falso

/ $/ 81$. I like to attend school plays.

1. True

2. False

I 82. I like to attend club activities.

1. True

2. Falso

L 83. I attend school sponsored events:

1. Regularly

2. Sometimes

3: When I have to
Never 
$\square$ 84. I am involved in:

1. Over 6 activities this year

2. 4 - 6 activities this yoar

3. $2-3$ activities this year

4. I activity this jear

5. No activities this jear

/ 85. I am not in any school activities because:

1. I prefar to be with my friends.

2. I work.

3. I have a nobby.

4. I have better things to do.

5. Activities are dumb.

6. I am al ready involved in school activities.

7. Other 


\section{PART III}

\section{Directions:}

Please put a check in the box on the left of the number for ang that apply.

What kind of sports would you like to be in?

86. Football

I 87. BasketbalI

I 88. Baseball

L/ 89. Track and Field

7 90. Swimming

I/ 91. Archery

/ 92. Tennis

/7 93. Gymnastics

fl 94. Plng-Pong

II 95. Pool.

/.I 96. Handball

/ / 97. Shooting and skeet

1. / 98. Ice Hockey

L 99. Fleld Hockey

$\square$ 100. Soccer

$\square$ 101. Dancing

/ / 102. vollegball

/ 103. Sking

/./ 204. Figure Skating

/./ 105. Badminton

/ I 106. Bowline

/./ 107. Weightlifting

/... 108. Wrestling

/.109. Raquetball 
$/$ / 210. Squash

$/$ /11. Judo

/ / 112. Karate

$/ / 113$. Other

$/ / 114$. Would you join a team that was on an intramural basis only? 3.. Yes

Would you join an activity that was involved in any of the following? (Please check the ones that interest you.)

7 115. Huntiag

116. Gunsmithing

T117. Fishing

I 118. Blacksmithing

T119. Canoeing

II 120. Trapplng

$\square$ 121. Rocis houndine

/ 122. Forestry

$\square$ 123. Ecology

$\square$ 124. Conservation

I 125. Government studies

$\square$ 126. Youth problems

$\Longrightarrow$ 127. Student-Faculty relationships

7 128. Law and society

/ 129. Inter-school Relat1onships

7 130. Forøign Languages

1./ 131. CB

T/132. Commercial and Ham Radio

I./ 133. Chess

\% / 134. Bridge 
T135. Monopols

/136. Scrabble or Probe

I 137. Card Games

138. Painting

T./ 139. Ceramics

1.1 140. Modeling

/ / 141. sculpture

$1 / 142$. Art shows

LI 143. Hand Crafts

Would you like to join a group to learn ang of the following: (Please check the ones you are interested in.)

/.../ 144. Music or Music Appreciation

/../ 145. Geology

/... 146. B1010gJ

$\square$ 147. Space and Astronomy

1.7 148. Chemistry

/ 149. Matb

T150. Plant Care

I151. Automobiles

I/ 152. History

/./ 153. Business

E/ 154. Ph110sophy

E. 155. Education

F/156. Soc10108y

/7 157. Astrology

I 158. Supernatural

/../ 159. Dramatic Arts

/ 160. Other (you suggest) 


\section{PART IV}

\section{Directions:}

You maj write in short answers.

1. What are your favorite activities thet are not sports?

2. What are your favorite sports?

3. What are your favorite out-of-school activities?

4. What student activities would gou like to see in this school? 
No.

ST. JOSEPH HIGH SCHOOL

STUDENT INTEREST QUESTIONNAIRE

Part II

The answers you put on the first questionnaire were tabulated electronically. The activity choices below are the results.

Directions

Do NOT put your name on this paper.

Put your choice in the box on the left of each question.

/ / 1. Age:

1. 14 or younger

2. 15

3. 16

4. 17

5. 18 or older

/. 2. Sex:

1. Male

2. Female

/ / 3. Grade:

I. 9 th

2. 10th

3. IIth

4. 12th

/ / 4. School Program

1. College prep

2. Vocational

3. Business

/ / 5. How are your school grades?

1. Mostly A's

2. Half $A^{\prime}$ 's and half $B^{\prime} s$

3. Mostly B's

4. Half B's and half C's

5. Mostly C's

6. Half C's and half D's

7. Mostly D's

8. Below D

/ / 6. What is your father's occupation (job)? 
$/ / 7$. What is the highest Ievel of your father's education?

1. Did not go to high school

2. Did not finish high school

3. High school graduate

4. Attended college or trade school

5. College graduate

6. Post college degree

7.. Doctorate degree

8. I do not know

/ / 8. Do you feel you have school spirit?

1. Yes

\section{Directions}

From the following list, select 3 or 4 different sports you'd like to be in. Put a check in the box on the leit of your choice.

sports

/ / 9. Football (school team)

/ / 10. Football (Intramural)

$/ / 11$. Girls "powder puff" football

/ / 12. Basketball (school team)

/ / 13. Basketball (Intramural - girls or boys)

/ / 14. Baseball (school team)

/ / 15. Baseball (Intramural)

/ / 16. Track and Field

/ / 17. Swimming (school team)

/ / 18. Swimming (Intramural and Recreational)

/ / 19. Archery

/ / 20. Tennis team

/ / 21. Tennis (Intramural and Recreational)

/ / 22. Gymnastics

/ / 23. Ping-Pong 
/ / 24. Pool

/ / 25. Shooting and skeet (Riflery)

/ / 26. Ice Hockey

/ / 27. Soccor (school team or Intramurals)

/ / 28. Girls Volleybali

/ / 29. Boys Volleyball

/ / 30. Snow Skiing

/ / 31. Water Skiing

/ / 32. Badminton

/ / 33. Bowling League

/ / 34. Racquetball

/ / 35. Judo

/ / 36. Karate

/ / 37. Cross Country

/ / 38. Handball

/ / 39. Roller Skating

/ / 40. Ice and Figure skating

$/ / 41$. Weightlifting

$/ / 42$. Wrestling

/ / 43. Boys Softball

/ / 44. Girls Softball.

/ / 45. Golf (Boys or Girls)

/. / 46. Eoxing

\section{Directions}

From the following list, select 3 or 4 different clubs that you'd like to join. Put a check in the box on the left of your choice.

clubs

/ / 47. Dance Club

/ / 48. Rock Bands 
/ / 49. Music lessons

/ / 50. A theatre group or drama club

/ / 51. Summer stock theatre

/ / 52. Photography

/ / 53. Debate team

$/ / 54$. Sewing and cooking club

$/$ /55. Camping and hiking club

/ / 56. Canoeing

/ / 57. Boating and sailing

/ / 58. Cinema club (movies)

/ / 59. Bike club

/ /60. Motorcycle club

/ /61. Auto club

/ / 62. Model craft club

/ / 63. Stereo club

/ / 64. Handcraft club

/ / 65. Woodworking and metal working club

/ / 66. Hunting and fishing club

/ / 67. Forestry and conservation club

/ / 68. Radio (CB, Ham)

/ / 69. Art club (painting, sculpture, shows, ceramics, etc.)

/ / 70. Card and game club

/ / 71. Music club

$/$ /72. Biology club

/ / 73. Space and astronomy club

/ /74. Math club

/ /75. Plant care club 
/ /76. Animal care club

/ / 77. History club

/ / 78. Business club

/ / 79. Sociology club

/ / 80. Supernatural

/ / 81. Philosophy

/ / 82. Youth problems

/ / 83. Law and society

/ / 84. Foreign language clubs

/ / 85. English club

/ / 86. Band

/ / 87. Choral

/ / 88. Newspaper

/ / 89. Yearbook

/ / 90. Class organizations

/ / 91. Honeybears

/ / 92. Cheerleaders

/ / 93. Nonsense activities (Frisbees, Tug-0-Wars, Skateboard Races; etc.) 
No.

\section{ST. JOSEPH HIGH SCHOOL}

\section{TEACHER'S QUESTIONNAIRE}

This questionnaire is complementary to the questionnaire given to a sampling of students, grades $9-12$, on the topic of activities interests. No employee of the st. Joseph School District will review this answer sheet.

\section{Directions}

Do NOT put your name on this paper.

Answer each question as best you can.

Put your choice in the box to the left of each question.

/ I. Sex:

1. Male

2. Female

$1 /$ 2. Age:

1. Under 25

2. $26-31$

3. $32-36$

4. $37-42$

5. 43 or over

3. Number of years of teaching experience:

1. Less than 5

2. $6-10$

3. $11-15$

4. $16-20$

5. Over 20

/ / 4. Highest degree held:

1. Bachelor's

2. Master's

3. Doctorate

/ / 5. Department (Choose the one that you do the majority of teaching in.)

1. History

2. English

3. Physical Education

4. Mathematics

5. Science

6. Business

7. Foreign languages

8. Industrial Education

9. Other 
/ / 6. Type of college you graduated from:

1. A Michigan public college

2. A Michigan private college

3. An out-of-state public college

4. An out-of-state private college

7. Please list your activities in high school.

8. Please list your college activities.

\section{Directions}

Below are the activities chosen by the students that they would like to see in the school. Please place a check mark in the box to the left of any item you would like to coach or advise or have an interest in.

\section{sports}

/ / 9. Football team

/ / 10. Football Intramurals

/ / 11. Girls "powder puff" football

/ / 12. Basketball team

/ / 13. Basketball (Intramurals - boys and girls)

/ / 14. Baseball team

/ / 15. Baseball Intramurals

/ / 16. Track and Field

$/$ 17. Swimming team

/ / 18. Swimming (Intramurals and Recreational)

/ / 19. Archery

$/ / 20$. Tennis team 
/ / 21. Tennis (Intramurals and Recreational).

/ / 22. Gymnastics

$/ / 23$. Ping Pong

/ / 24. Pool (Billiards)

/ / 25. Shooting, skeet, Riflery

/. / 26. Ice Hockey

/ $1: 27$. Soccor (school team or intramurals)

/ / 28. Girls Volleyball

/ $/$ 29. Boys Volleyball

/ / 30. Snow skiing

/ / 31. Water Sking

/ / 32. Badminton (Boys and Girls)

/ / 33. Bowling League

/ / 34. Racquetiall

/ / 35. Judo

/ / 36. Karate

/ / 37. Cross Country

/ / 38. Handball

/. / 39. Roller Skating

/ / 40. Ice and Figure Skating

$/ / 41$. Weightlifting

/ / 42. Wrestling

$/ / 43$. Boys Softball

/ / 44. Girls Softball

/ / 45. Golf

/ / 46. Boxing 
Clubs

/ / 47. Dance club

/ / 48. Rock Band

$/ /$ 49. Music lessons

/ / 50. Theatre or drama club

/ / 51. Summer Stock theatre

$/$ / 52. Photography club

/. / 53. Debate team

$/$ / 54. Sewing and cooking club

/ / 55. Camping and hiking club

$/$ / 56. Canoeing

/ / 57. Boating and sailing club

/ / 58. Cinema club

/ / 59. Biking club

/ / 60. Motorcycle club

$/ / 61$. Auto club

/ / 62. Model Craft club

/ / 63. Stereo club

/ / 64. Handcraft club

/ / 65. Woodworking and metal working club

$/ / 66$. Hunting and fishing club

/ / 67. Radio club (CB, Ham)

/ / 68. Art club

/ / 69. Card and game club

/ / 70. Music club

/ / 71. Biology club 
/. / 72. Space and Astronomy club

$/$ 73. Math club

/ / 74. Plant care club

/ / 75. Animal care club

/ / 76. History club

/ / 77. Business club

/ / 78. Sociology club

/ / 79. Supernatural

/ / 80. Philosophy club

/ / 81. Youth problems

/ / 82. Juaw and Society

/ / 83. Foreign language club

/ / 84. Band

/ / 85. Choral

/ / 86. Newspaper

/ / 87. Class organizations

/ / 88. Yearbook

/ / 89. Honeybears

/ / 90. Cheerleaders

/. / 91. Nonsense activities (Frisbee, Tug-0-War, Skateboard Races, etc.) 


\section{BRIDGMAN HIGH SCHOOL}

\section{STUDENT INTEREST QUESTIONNAIRE}

\section{Part II}

The answers you put on the first questionnaire were tabulated electronically. The activity choices below are the results.

\section{Directions}

Do lNOT put your name on this paper.

Put your choice in the box on the left of each question.

/ 1. Age:

1. 14 or younger

2. 15

3. 16

4. 17

5. 18 or older

/ / 2. S.ex:

1. Male

2. Female

/ / 3. Grade:

1. 9 th

2. 10th

3. IIth

4. 12 th

/ / 4. School Program:

1. College prep

2. Vocational

3. Business

$I^{\prime} / 5$. How are your school grades?

I. Mostly A's

2. Half $A^{\prime} S$ and half $B^{\prime} S$

3. Mostly B's

4. Half B's and half C's

5. Mostly C's

6. Half C's and half $D^{\prime} s$

7. Mostly D's

8. Below D

$/$ 6. What is your father's job (occupation)? 
1 / 7. What is the highest level of your father's education?

1. Did not go to high school

2. Did not finish high school

3. High school graduate

4. Attended college or trade school

5. College graduate

6. Post college degree

7. Doctorate degree

8. I do not know

/ / 8. Do you feel you have school spirit?

1. Yes

Directions

From the following list, select 3 or 4 different sports you'd like to be in. Put a check in the box on the left of your choice.

Sports

/ / 9. Football team

$/$ / 10. Football Intramurals

/ / 11. Girls Football

/ / 12. Basketball team

/ / 13. Basketball Intramurals

/ / 14. Baseball team

/ / 15. Baseball Intramurals

$/$ / 16. Track and Field

$/$ / 17. Swimming and Diving team

/ / 18. Swimming and Diving (Intramurals and Recreational)

/ / 19. Archery

/ / 20. Tennis Team

$/$ / 21. Tennis (Intramurals and Recreational)

/ 22. Gymnastics

$/$ / 23. Ping-Pong 


$$
\begin{aligned}
& \text { / / 24. Pool } \\
& / \text { / 25. Shooting, Skeet and Riflery } \\
& / \text { / 26. Handball } \\
& / \text { / 27. Field Hockey } \\
& / \text { / 28. Soccor } \\
& / \text { / 29. Girls Volleyball. } \\
& / \text { / 30. Boys Volleyball } \\
& / \text { / 31. Bowling } \\
& / \text { / 32. Snow Skiing } \\
& / \text { / 33. Water Skiing } \\
& / \text { / 34. Ice and Figure Skating } \\
& / \text { / 35. Judo } \\
& / \text { / 36. Karate } \\
& / \text { / 37. Ice Hockey } \\
& / \text { / 38. Weightlifting } \\
& / \text { / 39. Badminton } \\
& / \text { / 40. Cross Country } \\
& / \text { / 41. Golf } \\
& / \text { / } 42 . \text { Softball } \\
& / \text { / } 43 . \text { Wrestling }
\end{aligned}
$$

Directions

From the following list, select 3 or 4 different clubs that you'd like to join. Put a check in the box on the left of your choice.

Clubs

/ / 44. Hunting and fishing club

/ / 45. Canoeing

/ / 46. Forestry and Conservation club 
/ / 47. Youth problems

/ / 48. Law and Society

/ / 49. CB Radio club

/ / 50. Games (Chess, cards, Monolopy, etc.)

/ / 51. Art club (painting, ceramics, shows, etc.)

/ / 52. Hand Crafts.

/ / 53. Music and/or Music Appreciation

/ / 54. Biology Club

/ / 55. Plant Care Club

$/$ / 56. Auto club

/ / 57. Business club

/ / 58. Philosophy club

/ / 59: Education club.

/ / 60. Sociology club

/ / 61. Supernatural

/ / 62. Drama or Theatre group

/ / 63. Chemistry club

/ / 64. Gunsmitining

/ / 65. Geology club

/ / 66. Music lessons.

/ / 67. Biking club

/ / 68. Camping and hiking club

/ / 69. Motorcycle club

/ / 70. Rock Bands

$/$ / 71. Woodcrafting

/ / 72. Cooking and baking club

/ / 73. Cinema club (movies) 


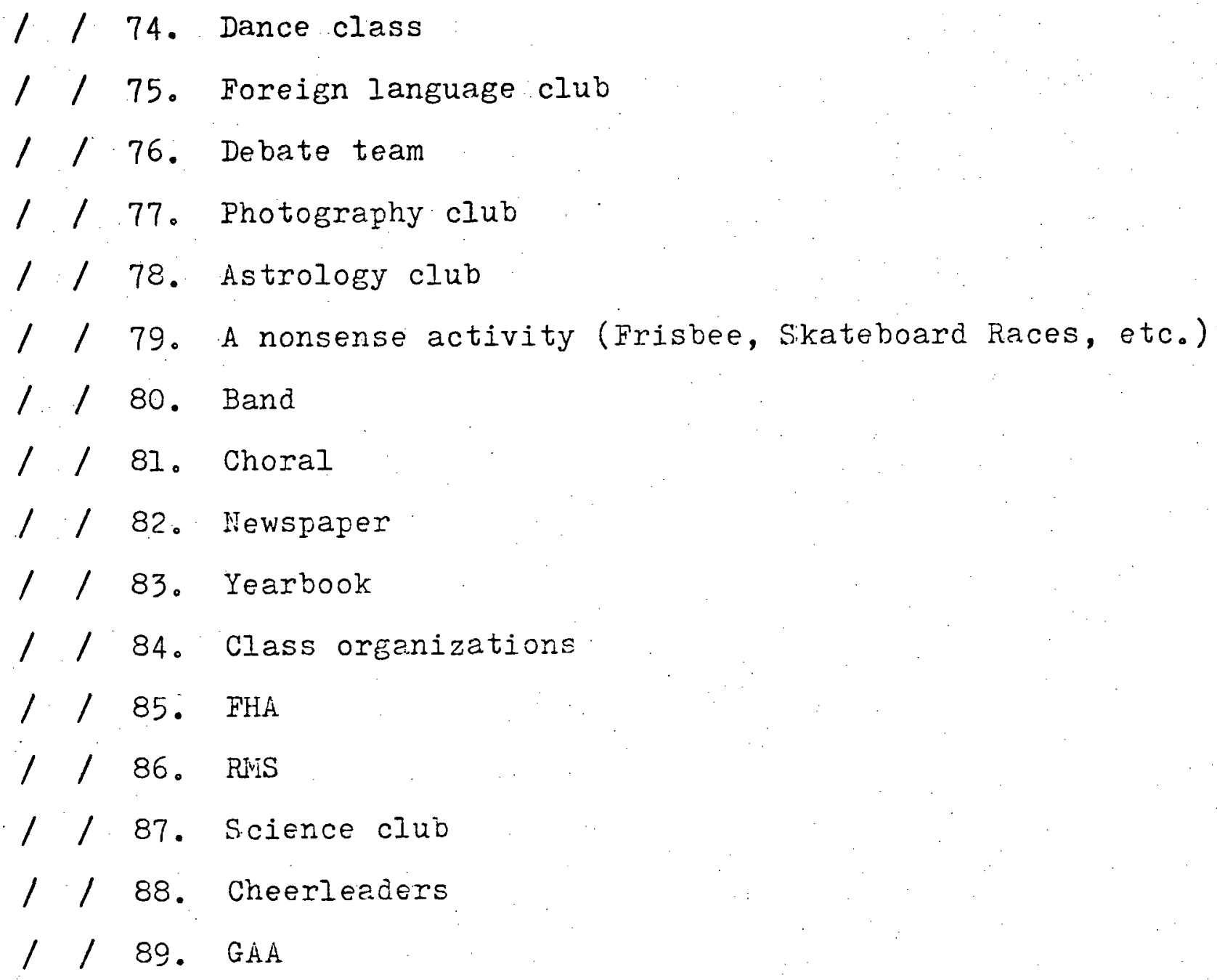


No.

\section{BRIDGMAN HIGH SCHOOI}

\section{TEACHER'S QUESTIONNAIRE}

This questionnaire is complementary to the questionnaire given to a sampling of students, grades $9-12$, on the topic of activities interests. No employee of the Bridgman school District will review this answer sheet.

\section{Directions}

Do NOT put your name on this paper.

Answer each question as best you can.

Put your choice in the box to the left of each question.

/. 1. Sex:

1. Male

2. Female

1 1 2. Age:

1. Under 25

2. $26-31$

3. $32-36$

4. $37-42$

5. 43 or over

/ / 3. Number of years of teaching experience

1. Jess than 5

2. $6-10$

3. $11-15$

4. $16-20$

5. Over 20

/ / 4. Highest degree held:

1. Báchelor's

2. Master's

3. Doctorate

/ / 5. Department (Choose the one that you do the majority of teaching in.).

1. History

2. English

3. Physical Education

4. Mathematics

5. Science

6. Business

7. Foreign Languages

8. Industrial Education

9. Other 
/ / 6. Type of college you graduated from:

1. A Michigan public college

2. A Michigan private college

3. An out-of-state public college

4. An out-of-state private college

7. Please list your activities in high school.

8. Please list your college activities.

\section{Directions}

Below are the activities chosen by the students that they would like to see in the school. Please place a check mark in the box to the left of any item you would like to coach or advise or have an interest in.

\section{Sports}

$1 /$ 9. Football team

/ / 10. Football Intramurals

/ / 11. Girls Football

/ / 12. Basketball team

/ / 13. Basketball Intramurals

/ / 14. Baseball team

/ / 15. Baseball Intramurals

/ / 16. Track and Field

/ / 17. Swimming and Diving team

1. / 18. Archery

/ / 19. Tennis team

$/ / 20$. Tennis (Intramurals and Recreational) 


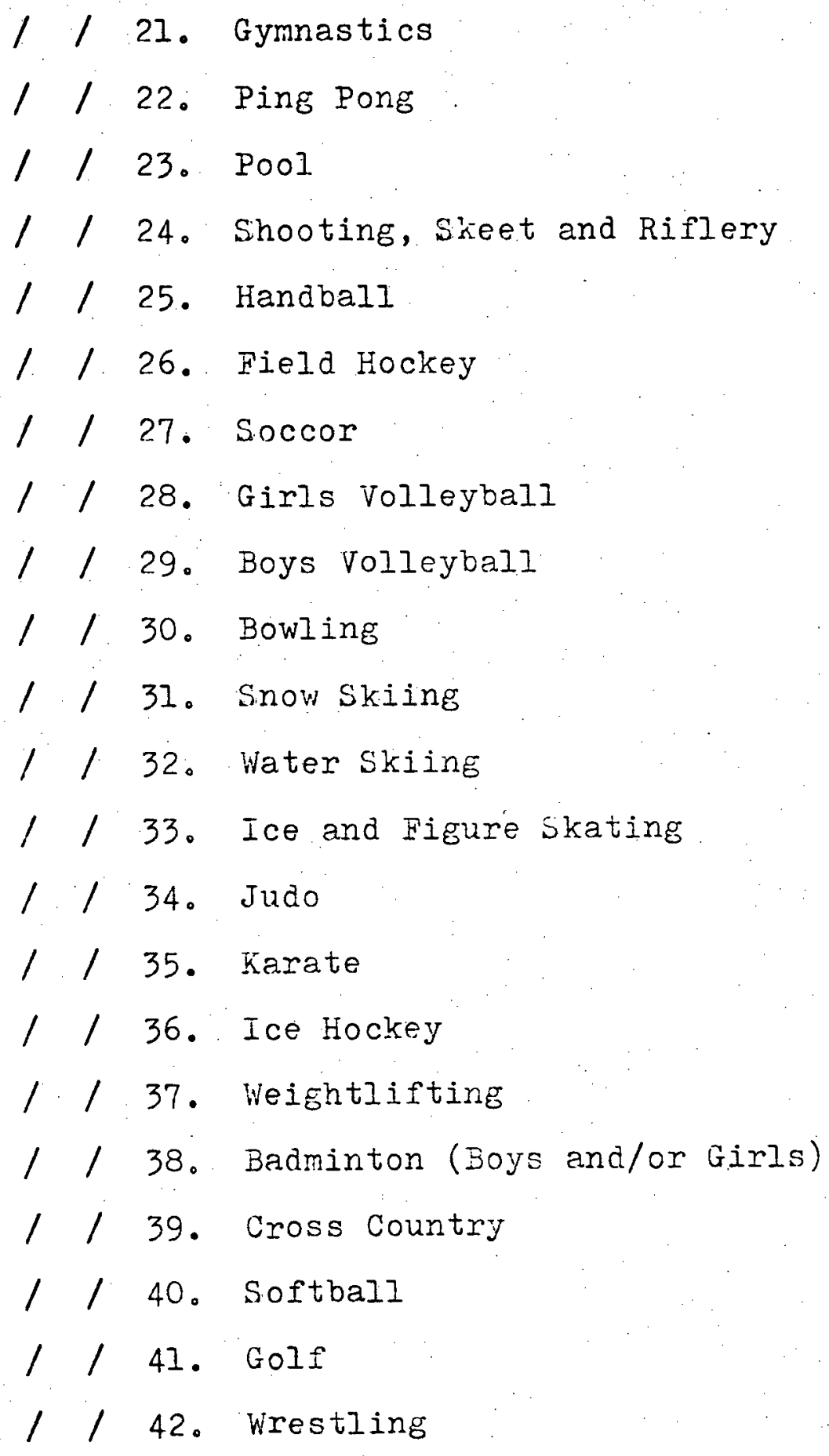

Clubs and Activities

/ / 43. Hunting and fishing

$/$ / 44. Canoeing

$/ / 45$. Forestry and Conservation 
/ / 46. Youth problems

/ / 47. Law and Society

$/$ / 48. CB Radio

/ / 49. Art club (painting, ceramics, shows, etc.)

$/ / 50$. Hand Crafts

/ / 51. Music or Music Appreciation

/ 52. Biology

/ / 53. Plant care

/ / 54. Auto club

/ / 55. Business club

/ / 56. Philosophy club

/ / 57. Education club

/ / 58. Sociology club

/ / 59. Supernatural

/ / 60. Drama or theatre group

/ / 61. Chemistry club

$/$ / 62. Gunsmithing

/ / 63. Geology

/. / 64. Music lessons

/ / 65. Biking club

/ / 66. Camping and hiking club

/ / 67. Motorcycle club

/ / 68. Cooking and baking club

/ / 69. Cinema (movies)

/ / 70. Dance class

/ / 71. Foreign language club 
/ / 72. Debate team

$/$ / 73. Photography club

/ / 74. Astrology

/ / 75. Nonsense activities (Frisbee, Skateboard Races, snow sculpture, etc。)

/ / 76. Band

/ / 77. Choral

/ / 78. Newspaper

/ / 79. Yearbook

/ / 80. Class organizations

$/ / 81$. FHA

$/ / 82$, RINS

/ / 83. Science club

/ / 84. Cheerleaders

$1 /$ 85. GAA 